\title{
Grout and Glass Performance in Support of Stabilization/ Solidification of ORNL Tank Sludges
}

\author{
R. D. Spence \\ C. H. Mattus \\ A. J. Mattus
}

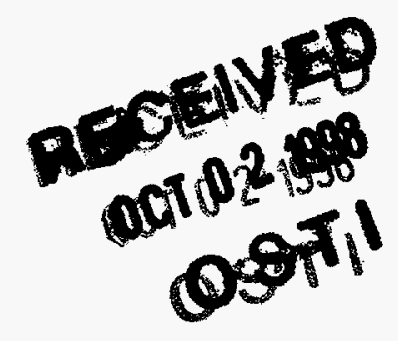

WNAGED ANO OPERATEO QY

LOCKHEED WAMM ENERGY RESEARCH CORPORATION

FOA THE UMTEO STATES

DERABTIENT OF ENERGY 
This report has been reproduced directly from the best available copy.

Available to DOE and DOE contractors from the Office of Scientific and Technical Information, P.O. Box 62, Oak Ridge, TN 37831; prices available from (615) 576-8401, FTS 626-8401.

Available to the public from the National Technical information Service, U.S. Department of Commerce, 5285 Port Royal Rd., Springfield, VA 22161.

This report was prepared as an account of work sponsored by an agency of the United States Government. Neither the United States Government nor any agency thereof, nor any of their employees, makes any warranty, express or implied. or assumes any legal liability or responsibility for the accuracy, completeness, or usefuiness of any information, apparatus, product, or process disclosed, or represents that its use would not infringe privately owned rights. Reference herein to any specific commercial product, process, or service by trade name, trademark, manufacturer, or otherwise, does not necessarily constitute or imply its endorsement, recommendation, or favoring by the United States Government or any agency thereof. The views and opinions of authors expressed herein do not necessarily state or reflect those of the United States Government or any agency thereof. 


\section{DISCLAIMER}

Portions of this document may be illegible in electronic image products. Images are produced from the best available original document. 
ORNL/TM-13653

Chemical Technology Division

\section{GROUT AND GLASS PERFORMANCE IN SUPPORT OF STABILIZATION/SOLIDIFICATION OF ORNL TANK SLUDGES}

R. D. Spence, C. H. Mattus, and A. J. Mattus

September 1998

Prepared by

OAK RIDGE NATIONAL LABORATORY

Oak Ridge, Tennessee 37831-6285 managed by

LOCKHEED MARTIN ENERGY RESEARCH CORP.

for the

U.S. DEPARTMENT OF ENERGY

under contract DE-AC05-96OR22464 



\section{CONTENTS}

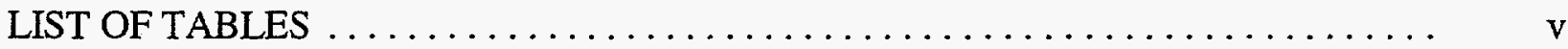

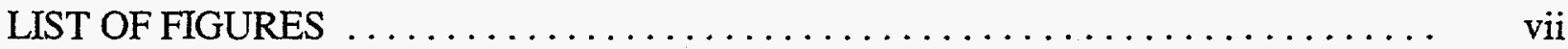

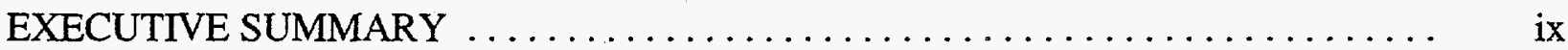

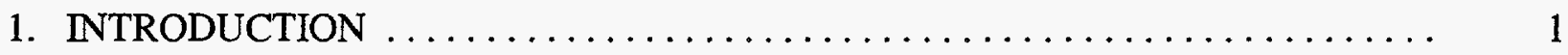

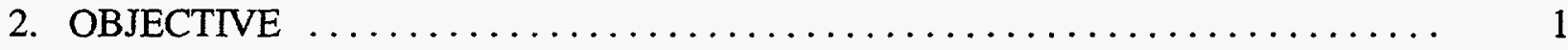

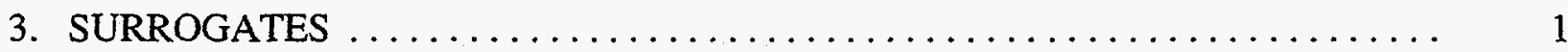

4. SELECTION OF THE DRY BLEND ADDITIVES FOR FURTHER

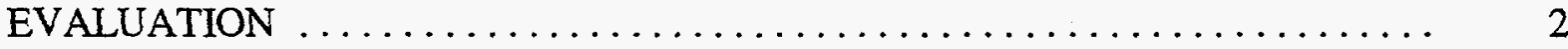

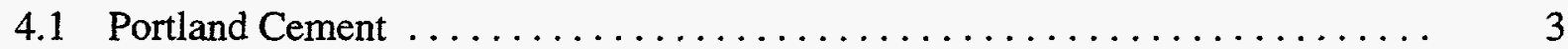

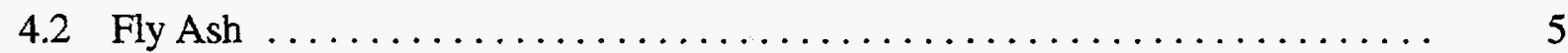

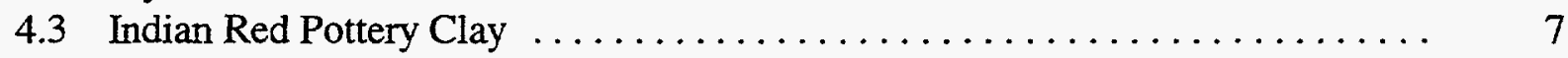

4.4 Ground Granulated Blast Furnace Slag ....................... 7

4.5 Water Sorptive Agents .............................. 9

4.6 Selecting Grout Composition for Evaluation $\ldots \ldots \ldots \ldots \ldots \ldots \ldots \ldots . \ldots \ldots$

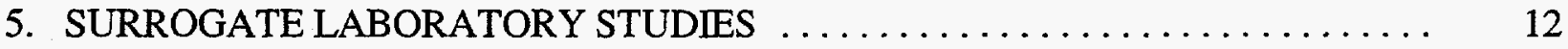

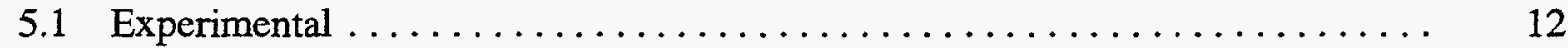

5.1.1 Surrogate Preparation $\ldots \ldots \ldots \ldots \ldots \ldots \ldots \ldots \ldots \ldots \ldots, 12$

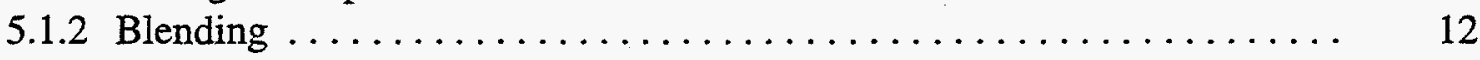

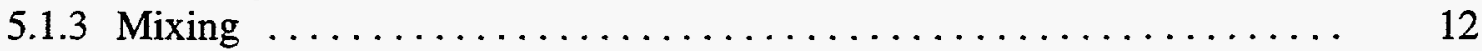

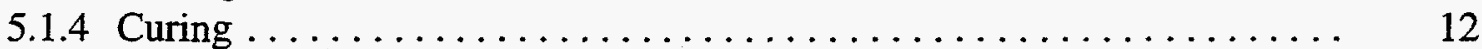

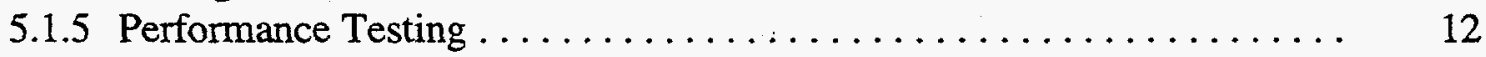

5.2 Overall Weighted Average Surrogate Sludge Results $\ldots \ldots \ldots \ldots \ldots \ldots \ldots$.

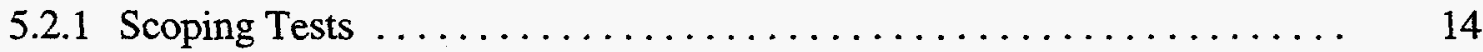

5.2 .2 Sensitivity Testing $\ldots \ldots \ldots \ldots \ldots \ldots \ldots \ldots \ldots \ldots \ldots \ldots \ldots \ldots \ldots \ldots, 15$

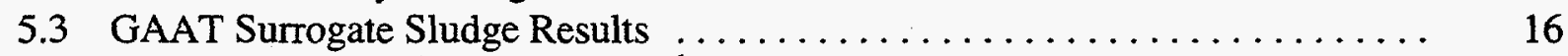

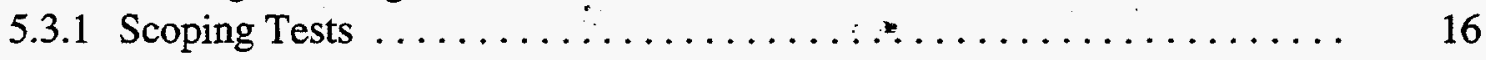

5.3 .2 Sensitivity Testing $\ldots \ldots \ldots \ldots \ldots \ldots \ldots \ldots \ldots \ldots \ldots \ldots \ldots \ldots \ldots \ldots, 17$

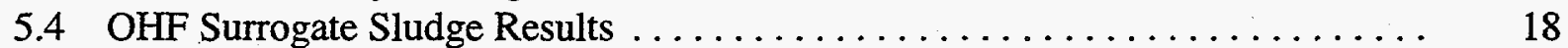

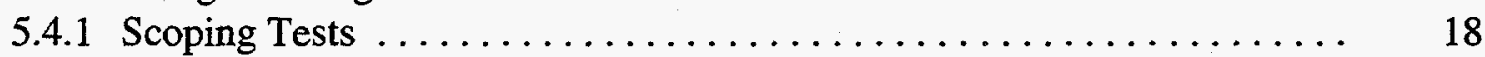

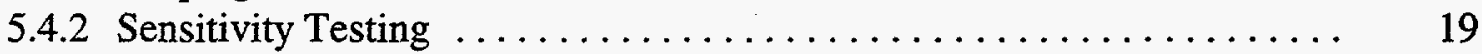

5.5 Testing Performance for Beryllium in TCLP $\ldots \ldots \ldots \ldots \ldots \ldots \ldots \ldots .20$

5.6 Effect of IRPC on Leachability Index .......................... 20

6. TESTING OF W25 SLUDGE SAMPLE ........................ 20

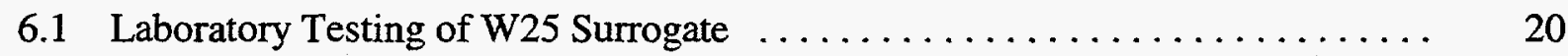

6.2 Hot Cell Wasteform Preparation .......................... 21

6.2.1 Waste Sludge Composition and Properties $\ldots \ldots \ldots \ldots \ldots \ldots \ldots .21$

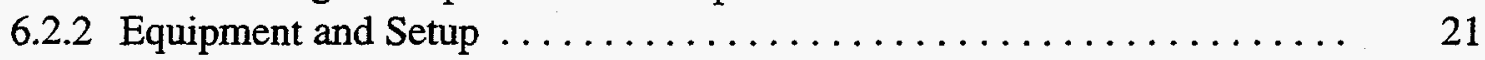

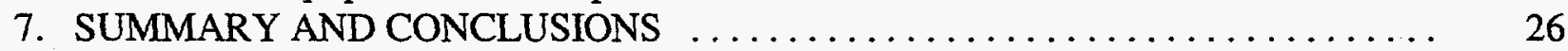

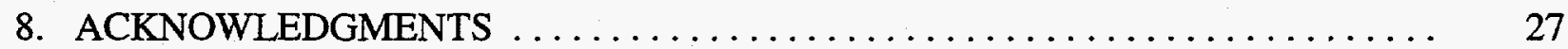

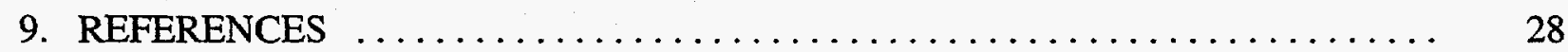

APPENDIX: HOT CELL D AND EQUIPMENT $\ldots \ldots \ldots \ldots \ldots \ldots \ldots \ldots \ldots \ldots, 35$ 



\section{LIST OF TABLES}

1 Summary of ORNL tank sludge surrogate compositions ..............

2 Overall weighted average surrogate sludge: grout compositions

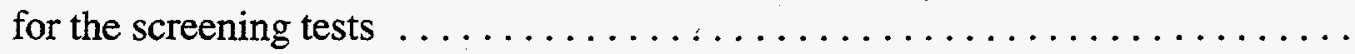

3 Overall weighted average surrogate sludge: free water and penetration resistance results for the screening tests $\ldots \ldots \ldots \ldots \ldots \ldots \ldots \ldots \ldots$

4 Overall weighted average surrogate sludge: TCLP results for the

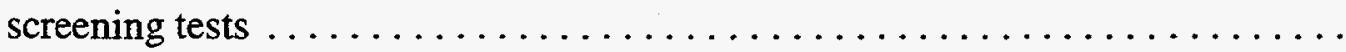

5 Overall weighted average surrogate sludge: grout density and grout/sludge volume ratio results for the screening tests $\ldots \ldots \ldots \ldots \ldots \ldots \ldots \ldots \ldots, 45$

6 Grout composition for sensitivity testing of surrogate sludges ........... 46

7 Surrogate recipes for the sensitivity tests: overall average composition of ORNL tank sludges (OHF, GAAT, BVEST, and MVST) ............

8 Overall weighted average tank sludge sensitivity test results: measured bulk grout densities and calculated grout/sludge volume ratios ...........

9 Overall weighted average tank sludge sensitivity test results: measured

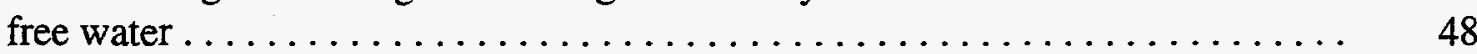

10 Overall weighted average tank sludge sensitivity test results: unconfined

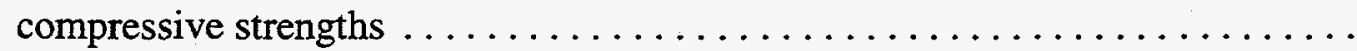

11 Overall weighted average tank sludge sensitivity test results: TCLP

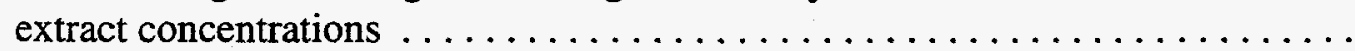

12 Overall weighted average tank sludge sensitivity test results: leachability

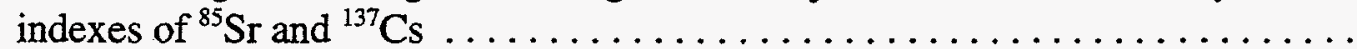

13 GATT surrogate sludge: grout compositions for the screening tests $\ldots \ldots \ldots$

14 GATT surrogate sludge: free water and penetration resistance results for the screening tests $\ldots \ldots \ldots \ldots \ldots \ldots \ldots \ldots \ldots \ldots \ldots, 52$

15 GAAT surrogate sludge: TCLP results for the screening tests $\ldots \ldots \ldots \ldots \ldots$

16 GAAT surrogate sludge: grout density and grout/sludge volume ratio

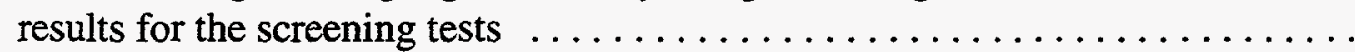

17 Surrogate recipes for the sensitivity tests: gunite and associated

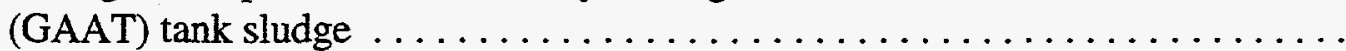

18 GAAT sludge sensitivity test results: measured bulk grout densities and calculated grout/sludge volume ratio $\ldots \ldots \ldots \ldots \ldots \ldots \ldots \ldots \ldots, 56$

19 GAAT sludge sensitivity test results: measured free water $\ldots \ldots \ldots \ldots \ldots .56$

20 GAAT sludge sensitivity test results: unconfined compressive strengths $\ldots \ldots .56$

21 GAAT sludge sensitivity test results: TCLP extract concentrations .......... 57

22 GAAT sludge sensitivity test results: leachability indexes of ${ }^{85} \mathrm{Sr}$ and ${ }^{137} \mathrm{Cs} \ldots . \quad 58$

23 Old hydrofracture surrogate sludge: grout compositions for the

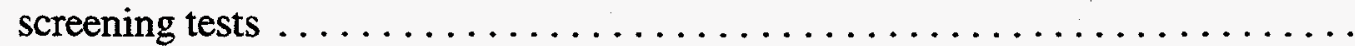

24 Old hydrofracture surrogate sludge: free water and penetration

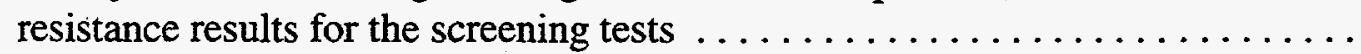


26 OHF surrogate sludge: grout density and grout/sludge volume ratio results

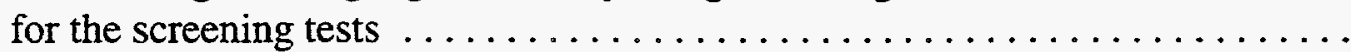

27 Surrogate recipes for the sensitivity tests: old hydrofracture

(OHF) tank sludge

OHF sludge sensitivity test results: measured bulk grout densities and calculated grout/sludge volume ratio $\ldots \ldots \ldots \ldots \ldots \ldots \ldots \ldots \ldots \ldots \ldots$

OHF sludge sensitivity test results: measured free water

OHF sludge sensitivity test results: unconfined compressive strengths . . . . .

OHF sludge sensitivity test results: TCLP extract concentration $\ldots \ldots \ldots \ldots$

Testing the standard dry blend at $55 \mathrm{wt} \%$ sludge loading varying the

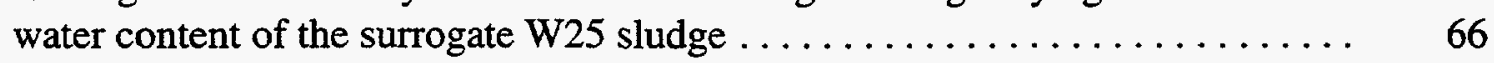
Chemical composition of actual W25 sludge

Chemical composition of the surrogate sludge representing tank W25 


\section{LIST OF FIGURES}

Figure

Page

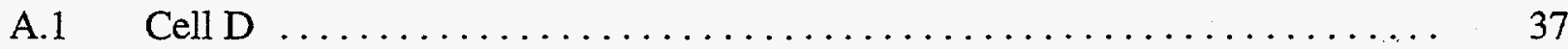

A.2 Equipment installed in Cell D . ........................ 38

1 Testing free water with variations on the dry blend developed for the overall weighted average surrogate sludge (grout series $01-07$ ) $\ldots \ldots \ldots \ldots \quad 72$

2 Testing penetration resistance with variations on the dry blend developed for the overall weighted average surrogate sludge (grout series 01-07) ...... 73

3 Testing free water and variations on the dry blend developed for the overall weighted average surrogate sludge (grout series $01-07$ ) $\ldots \ldots \ldots \ldots \quad 74$

4 Testing free water and penetration resistance at a constant W/S of 0.5 (overall weighted average grout series OA1-OA7; water/solids $=0.50$ ) $\ldots \ldots$.

5 Testing free water and penetration resistance at a constant loading of 60 wt \% (overall weighted average grout series OB1-OB8; wet

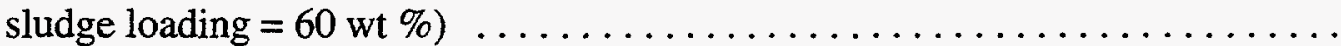

6 Free water and penetration resistance with time for $60 \mathrm{wt} \%$ wet sludge and W/S of 0.625 (overall weighted average grout series OB1-OB8; wet sludge loading $=60 \mathrm{wt} \%$; water/solids $=0.625) \ldots \ldots \ldots \ldots \ldots \ldots$

7 Free water and penetration resistance testing lower perlite contents in the dry blend (overall weighted average grout series OC1-OC6) $\ldots \ldots \ldots$

8 Free water testing replacing perlite in the dry blend with attapulgite: sheared and nonsheared (overall weighted average grout

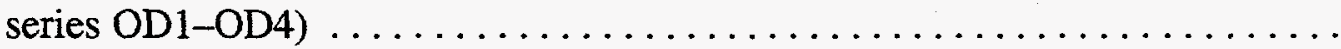

9 Free water testing replacing perlite in the dry blend with attapulgite: sheared and nonsheared (overall weighted average grout series OD1-OD4) .............................. 80

10 Free water and penetration resistance testing varying waste loading and W/S (overall weighted average grout series OF1-OF11) ........... 81

11 TCLP extract concentration of chromium with wet sludge loading for the overall weighted average surrogate sludge $\ldots \ldots \ldots \ldots \ldots \ldots \ldots . \quad 82$

12 Free water and penetration resistance with wet sludge loading and W/S (grout series GAAT1-GAAT14) $\ldots \ldots \ldots \ldots \ldots \ldots \ldots \ldots \ldots$

13 Free water and penetration resistance with wet sludge loading

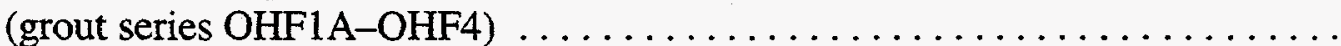

14 Free water and penetration resistance testing varying perlite in the dry blend (grout series OHF1, OHF5-OHF8) $\ldots \ldots \ldots \ldots \ldots \ldots \ldots \ldots$

15 Leachability index as a function of the IRPC in the dry blend varying IRPC in the overall weighted average standard sensitivity grout .......... 



\section{EXECUTIVE SUMMARY}

Grouting and vitrification are currently two likely stabilization/solidification alternatives for radioactive and hazardous mixed wastes stored at Department of Energy facilities. Grouting has been used to stabilize/solidify hazardous and low-level radioactive waste for decades.

Vitrification has been developed as a high-level radioactive alternative for decades and has been under development recently as an alternative disposal technology for mixed waste.

Wastewater at the Oak Ridge National Laboratory (ORNL) is collected, evaporated, and stored in the Melton Valley Storage Tanks (MVST) and Bethel Valley Evaporator Storage Tanks (BVEST) pending treatment for disposal. In addition, some sludges and supernatants also requiring treatment remain in two inactive tank systems: the gunite and associated tanks and the old hydrofracture facility tanks. The sludges contain a high amount of radioactivity, and some are classified as transuranic (TRU) sludges. Some Resource Conservation and Recovery Act (RCRA) metal concentrations are high enough to be defined as RCRA hazardous; therefore, these sludges are presumed to be mixed TRU waste.

Robust grout and glass formulations capable of solidifying of all ORNL tank sludges were developed. The formulations were tested on weighted average surrogates for each tank farm set, a weighted average composite, and a sludge from one tank (W25) in the MVST farm set. Testing was performed on an actual sludge sample from W25, as well as a surrogate of this W25 sludge sample. Waste forms produced from the sample of actual W25 sludge performed similarly to a surrogate for that tank sludge, indicating that the results obtained for the surrogates were representative of that for tank sludges. This report documents the development of the grout formulation and its testing with the surrogate sludges during FY 1997, plus the testing of both the grout and glass formulations with the hot sludge sample.

A sample of W25 sludge had been previously obtained for another project and was the only sample of hot sludge available for testing the formulations during the FY 1997 studies. The composition of the sludge sample from W25 used for hot testing was an outlier among the set of characterization data for the MVST/BVEST sludges (not realized until comparison of the characterization data for this sample with the tank sludge characterization reports prior to using the sample in the hot tests). For this reason, a surrogate was designed specifically for the W25 sample and tested with the formulation designed in FY 1996 for the MVST set. Waste forms produced from the W25 surrogate performed significantly different from those using an average surrogate for this set of tanks. These differences illustrate that the performance for a given sample or a given tank sludge may be quite different from the performance for a surrogate based on an average composition. A robust formulation must be designed to account for this performance variation so that applicable disposal criteria are met.

The robust grout formulation at a sludge loading of $60 \mathrm{wt} \%$ was effective for the variation in surrogate sludge composition representing the ORNL tank sludges. Grout sludge loading was limited by chromium leaching in the Toxicity Characteristics Leaching Procedure (TCLP) test, bleed water, and strength performance. If the water-to-solids ratio (W/S) of the grout was controlled, sludge loadings as high as $90 \mathrm{wt} \%$ could be used without bleed water. The chromium 
TCLP performance or strength performance criteria would limit the loading to $<70 \mathrm{wt} \%$. The limited available data imply that the chromium present in the actual ORNL tank sludges is in the trivalent form rather than the hexavalent or chromate form. This means that the chromium actually present in the sludge does not require stabilization and, if there is no strength criterion, sludge loadings as high as $90 \mathrm{wt} \%$ can be used by controlling the W/S. Sludge loadings this high may result in volume increases of $<10 \mathrm{vol} \%$.

The Savannah River Technology Center (SRTC) refined the soda-lime-silica (SLS) glass, originally developed by ORNL for MVST sludge. The glass had no problems meeting the Universal Treatment Standards limits under RCRA. On the other hand, the untreated W25 sludge sample failed TCLP for mercury. Although the glass did not fail the TCLP for mercury (or any RCRA metal), mercury is not stabilized in glass, since it volatilizes during vitrification and must be captured from the off-gas and handled as a secondary waste. Lowering the glass melt temperature from $1400^{\circ} \mathrm{C}$ to $1300^{\circ} \mathrm{C}$ assisted in controlling cesium volatility, but close to $60 \mathrm{wt} \%$ of the ${ }^{137} \mathrm{Cs}$ may have volatilized in the simple crucible vitrification of the W25 sludge sample. Field operations employ schemes, such as cold caps, to control ${ }^{137} \mathrm{Cs}$ volatilization. Further refinements should be possible to improve vitrification and the performance of the glass product. Further details regarding the performance of the SLS glass will be provided by SRTC in a separate report.

In summary, both the grout and SLS glass effectively stabilized the contaminants that were retained in the waste form. Mercury, the RCRA metal for which the W25 sample was characteristically hazardous, volatilizes during vitrification and must be trapped and treated in the vitrification secondary wastes. The grout effectively stabilized the mercury in the W25 sample. Grouting at a sludge loading of $60 \mathrm{wt} \%$ is expected to increase the volume by about $32 \mathrm{vol} \%$ over the existing sludge volume, and vitrification is expected to decrease the volume by about $56 \mathrm{vol} \%$. This leads directly to an increase in packaging and disposal costs for the increased volume of grout over glass. ORNL will perform additional refinements to the grout formulation in FY 1998 and tailor the formulation for specific ORNL tank sludges to maximize sludge loading and minimize volume increase. SRTC will perform additional refinements to the glass formula in FY 1998 and tailor the formula for specific ORNL tank sludges. 


\section{INTRODUCTION}

Wastewater at Oak Ridge National Laboratory (ORNL) is collected, evaporated, and stored in the Melton Valley Storage Tanks (MVST) and Bethel Valley Evaporator Storage Tanks (BVEST) pending treatment for disposal. In addition, some sludges and supernatants also requiring treatment remain in two inactive tank systems: the gunite and associated tanks (GAAT) and the old hydrofracture (OHF) tank. The waste consists of two phases: sludge and supernatant. The sludges contain a high amount of radioactivity, and some are classified as TRU sludges. Some Resource Conservation and Recovery Act (RCRA) metal concentrations are high enough to be defined as RCRA hazardous; therefore, these sludges are presumed to be mixed TRU waste.

Grouting and vitrification are currently two likely stabilization/solidification alternatives for mixed wastes. Grouting has been used to stabilize/solidify hazardous and low-level radioactive waste for decades. Vitrification has been developed as a high-level radioactive alternative for decades and has been under development recently as an alternative disposal technology for mixed waste.

\section{OBJECTIVE}

The objective of this project is to define an envelope, or operating window, for grout and glass formulations for ORNL tank sludges. Formulations will be defined for the average composition of each of the major tank farms (BVEST/MVST, GAAT, and OHF) and for an overall average composition of all tank farms. This objective is to be accomplished using surrogates of the tank sludges with "hot" testing of actual tank sludges to check the efficacy of the surrogates.

\section{SURROGATES}

The following four surrogate compositions were developed for this study: one for each of the GAAT and OHF tank farms, an average surrogate sludge to simulate mixing of the sludge presently in inventory (defined in this report as the overall weighted average, or overall, surrogate sludge), and MVST W25. One surrogate-MVST/BVEST tank farm surrogate-was developed and tested last fiscal year. ${ }^{1}$ These surrogate compositions are listed in Table 1.

The composition of the ORNL tank sludges was estimated using the available characterization data. ${ }^{2-6}$ This characterization data mainly reports the elemental concentrations, although the inorganic carbon (IC) and total organic carbon (TOC) were reported for the sludge and some anions were reported. The weighted average from reference 2 was used for the two data sets studied: overall surrogate sludge and OHF surrogate sludge. A surrogate sludge for the MVST/BVEST was developed in FY $1996 .{ }^{1}$ In addition, the surrogate sludge developed for vitrification studies was the basis for the GAAT surrogate sludge.? 
A sample of W25 sludge had been previously obtained for another project and was the only sample of hot sludge available for testing the formulations during the FY 1997 studies. The composition of the sludge sample from W25 used for hot testing was an outlier among the set of characterization data for the MVST/BVEST sludges (not realized until comparison of the characterization data for this sample with the tank sludge characterization reports prior to using the sample in the hot tests). The W25 surrogate was designed specifically to simulate the sample of "hot" sludge from Tank W25. The performance of this W25 surrogate was significantly different from the weighted average surrogate developed for MVST/BVEST ${ }^{1}$ but quite similar to that of the actual W25 sample.

For the purposes of developing surrogates, the IC was assumed to be carbonate. The soluble anions in the sludges were assumed to be sodium salts, and potassium was assumed to be present as the nitrate. The undissolved solids were assumed to be mainly alkaline carbonates and hydroxides. This approach generally accounted for the anions that were reported in the data, though some mixtures of alkali carbonates and hydroxides were sometimes used to balance the anions and cations. The TOC was added as tributylphosphate (TBP), and the measured oxalate was added as calcium oxalate. In general, the reported elemental phosphorus concentration for the tank sludges exceeded the phosphorus contained in the TBP, so the remaining phosphorus for the surrogate was added as sodium phosphate. (The reported elemental phosphorus concentrations were high because of interference effects in the inductively coupled plasma analyses. Since the surrogate phosphate content was based on this falsely high measurement, in general, the surrogates contain more phosphorus than the average of the tank sludges.) The remainder of the measured elements were assumed to be oxides, although the trace RCRA metals were added as various convenient compounds, in an attempt to close the mass balance and identify whether a large unknown mass had not been characterized in the sludge. Excellent mass balance closure was achieved with this approach. The compound concentrations estimated from the weighted average characterization data were adjusted to total $100 \mathrm{wt} \%$ for the surrogate recipes used in this work.

\section{SELECTION OF THE DRY BLEND ADDITIVES FOR FURTHER EVALUATION}

The historical inorganic additives used for stabilization/solidification are portland cement, fly ash, lime, and clay but also include blast furnace slag, cement kiln dust, high alumina cements, natural pozzolans, masonry cements, special cements, and cement admixtures. ${ }^{8,9}$ Conner cites the following reasons for the widespread use of these materials in treating wastes: ${ }^{8}$

- Relatively low cost

- Good long-term stability, both physically and chemically

- Documented use on a variety of industrial wastes over a period of at least ten years

- Widespread availability of the chemical ingredients

- Nontoxicity of the chemical ingredients

- Ease of use in processing (processing normally operated at ambient temperature and pressure and without unique or very special equipment) 
- Wide range of volume increase

- Inertness to ultraviolet radiation

- High resistance to biodegradation

- Low water solubility

- Relatively low water permeability

- Good mechanical and structural characteristics

The International Atomic Energy Agency lists the following advantages and disadvantages of cement for the solidification of radioactive wastes: ${ }^{9}$

\section{Advantages}

- Material and technology well known

- Compatible with many types of waste

- Most aqueous wastes chemically bound to matrix

- Low cost of cement

- Good self-shielding

- No vapor problems

- Long shelf life of cement powder

- Good impact and compressive strengths

- Low leachability for some radionuclides

- No free water if properly formulated

- Rapid, controllable setting, without settling or segregation during curing

\section{Disadvantages}

- Some wastes affect setting or otherwise produce poor waste forms.

- Adjustment of waste $\mathrm{pH}$ may be necessary.

- Swelling and cracking occur with some products when they are exposed to water.

- Volume increase and high density may develop.

- Excessive heat may develop during setting with certain combinations of cement and waste.

- Dust problems may occur with some systems.

- Equipment for powder feeding is difficult to maintain.

- Potential maintenance problems may result from premature cement setting, especially in the case of in-line mixers.

Portland cement, fly ash, Indian Red Pottery Clay (IRPC), ground granulated blast furnace slag, and water sorptive agents were selected for use in this study. A brief history and reason for selection are presented in the following subsections for each material.

\subsection{PORTLAND CEMENT}

Portland cement, its composition, and its chemistry are discussed in great detail in other publications and will not be discussed in detail in this report. ${ }^{8-14}$ The main points of interest for cement stabilization/solidification are (1) the normally high $\mathrm{pH}$ of cement matrices, (2) the 
production of calcium hydroxide in normal cement hydration, and (3) the strong binding matrix, resistant to advective water flow, and leaching that interacts with and encapsulates the waste. Wastes are generally physically encapsulated heterogeneously in the calcium-silicate-hydrate (CSH) matrix, with the level of dispersion and homogeneity generally dependent on the energy and effort put into physically mixing waste and cement. Despite the inherent composite nature of cement waste forms, the wastes strongly interact with the cement, stabilizing contaminants as desired and sometimes interfering with cement hydration, which is not desired. Although there is evidence that some contaminants are incorporated into the CSH matrix, the main stabilizing mechanism of cement waste forms is the high $\mathrm{pH}$ matrix, similar to the lime precipitation of metals in wastewater treatment.

This high pH precipitation captures the majority of the RCRA metals and radionuclides. For example, the low solubility at high $\mathrm{pH}$ of copper, nickel, iron, cadmium, zinc, silver, and lead are illustrated in the published solubility curves with $\mathrm{pH} .^{8,15}$ In general, these solubility curves pass through a minimum as the $\mathrm{pH}$ increases, meaning these metals actually start becoming more soluble when the $\mathrm{pH}$ passes a certain point, with the generation of complex hydroxide ions. The minimum solubility for these metals occurs in a pH range of about 9 to slightly more than 11 . The normal production of calcium hydroxide during cement hydration and the presence of alkalis in the cement can produce a pore solution $\mathrm{pH}$ in the range of $12-13$, well above the minimum solubility for most of these metals. ${ }^{8}$ This combination (high matrix $\mathrm{pH}$ and increasing metal solubility at this $\mathrm{pH}$ level) can actually increase the leachability of some wastes after treatment. This is one reason neat cement pastes (i.e., pastes consisting only of mixtures of cement and water) are a poor choice for stabilizing wastes and why cement-fly ash combinations are almost always used. Fly ash consumes the calcium hydroxide produced during cement hydration, moderating the matrix $\mathrm{pH}$ and eliminating the large soluble portlandite crystals found in neat cement pastes. These crystals dissolve upon immersion, leaving large accessible pores in the matrix, thus increasing porosity and leachability. Cementitious waste forms (typically, cement-fly ash) reportedly have a $\mathrm{pH}$ of about 11 , which is much better suited for minimizing metal solubility. ${ }^{16}$ The solubility behavior of the RCRA metals in cement waste forms mimics these solubility curves to a certain degree but differ enough to illustrate that ". . factors other than hydroxide precipitation are in operation. . . "8,17

Cements are produced and sold in many forms, any of which may be suitable for stabilizing wastes. Portland cements are the most commonly available cements, typically locally available and cheap. The ASTM standards specify five standard portland cements with optional properties available within each type (ASTM C 150-89):

$\begin{gathered}\text { ASTM type } \\ \text { portland cement }\end{gathered}$
I


Low heat of hydration; used in massive structures (e.g., dams) where temperature rise can approach adiabatic; generally not available; mass produced for specific jobs

Sulfate resistant

ASTM Type I portland cement is most commonly used for waste stabilization because of its wider availability and lower cost and because it can work in most cases with proper tailoring. The way the ASTM specifications are written, ASTM Type II portland cement can be considered a subset of ASTM Type I portland cement, and quite often cement is marketed as Type I-II portland cement. If Type II portland cement is locally available, it may be better to specify Type II because of its better sulfate resistance and lower heat of hydration. (Many wastes contain sulfate, and the heat of hydration can be a concern for some waste form applications.) In addition, specifying the options of low alkali (LA) and low alumina (if available) may be desirable to make the final waste form more resistant to later destructive expansion from minerals, such as alkali silicates, ettringite, or calcium chloroaluminate.

In summary, the best a priori cement selection may be ASTM Type II portland cement-LA-low alumina-moderate heat of hydration. However, any of the cement types may be satisfactory for a given application, and such selections should be made on a case-by-case basis, depending on waste composition, cement availability, technical performance, and costs. In the present study, the main function of the cement selected was to ensure activation of the ground granulated blast furnace slag; hence, it was not necessary to specify the type of cement since it would not provide the basic waste form matrix. Type I, Type II, or Type I-II would be equally appropriate for this task, although Type II or I-II would still be preferred, if readily available, because of better sulfate resistance.

\subsection{FLY ASH}

Fly ash is an active pozzolan source that reacts with the caustic alkalis and alkalines, consuming hydroxide and producing alkali silicates and more CSH. Fly ash is only one of several possible pozzolans that can be used with cement or lime to produce cementitious waste forms. Other pozzolan candidates include volcanic glasses, volcanic tuffs, calcined clays and shales, diatomites, rice husk ash, volatilized silica (silica fume), blast furnace slag, and other slags. ${ }^{9}$ The key to the reactivity of the fly ash (and many of the other pozzolans) is its glassy structure. Only the amorphous glassy form provides a soluble silica source for reacting with the lime (and other caustics). The crystalline forms, like mullite, are too insoluble, stable, and inert. Fly ash was used in construction concrete decades prior to its use in waste disposal. . $^{8,919-23}$

Using fly ash in concrete has many advantages in certain usages, the most important being cost, as it replaces $25-35 \mathrm{wt} \%$ of the portland cement normally used. ${ }^{8}$ Incorporating fly ash into cement lowers the heat of hydration, reducing curing temperature, an advantage in producing massive monoliths. ${ }^{9,21-23}$ Fly ash acts as both a pozzolan and a bulking agent, helping to prevent 
settling in relatively low solids wastes and saving costs by substituting for cement. ${ }^{8}$ However, such bulking does result in a larger volume and weight increase than for portland cement alone, "... usually only justified where low handling, transportation, and disposal costs are encountered." However, the relatively higher volume from fly ash is acceptable in its use as a pozzolan. Hydrating cement produces lime as a by-product that forms large soluble crystals in the cured neat cement paste matrix. These crystals dissolve upon immersion, leading to increased accessible porosity and leachability. Pozzolans react with this lime to produce more CSH to fill the available porosity, decreasing accessible porosity and leachability. In other words, fly ash “... helps to bind additional water, decrease the pore $\mathrm{pH}$, and act as an adsorbent for metal ions."

Since strontium behaves similarly to calcium, cement-pozzolans will also tend to tie up ${ }^{90} \mathrm{Sr}$ better than cement alone. Cement-fly ash has traditionally been the stabilizer of choice for ${ }^{90} \mathrm{Sr}$, although cement alone does stabilize ${ }^{90} \mathrm{Sr}$ quite well. ${ }^{19,24-27}$

The ASTM standards specify two fly ashes and one natural or calcined pozzolan for use in Portland cement concrete (ASTM C $618-91$ ): ${ }^{8,28}$

\begin{tabular}{|c|c|}
\hline $\begin{array}{l}\text { ASTM mineral } \\
\text { admixture class }\end{array}$ & Description \\
\hline $\mathbf{N}$ & Raw or calcined natural pozzolans \\
\hline $\mathrm{F}$ & $\begin{array}{l}\text { Fly ash normally produced from anthracite or } \\
\text { bituminous coal; has pozzolanic properties }\end{array}$ \\
\hline $\mathrm{C}$ & $\begin{array}{l}\text { Fly ash normally produced from lignite or } \\
\text { subbituminous coal; has pozzolanic and } \\
\text { cementitious properties; may contain lime }>10 \%\end{array}$ \\
\hline
\end{tabular}

In general, a commercial industry has evolved to supply fly ash cheaply and with adequate QA/QC to routinely meet ASTM standards, making a valuable by-product from the large amounts of waste produced daily in the coal-fired power plants across the country. Although both can be and have been used, ASTM Class F fly ash is generally preferred for waste treatment because of the possibility of "flash set" in the equipment with ASTM Class C fly ash. This difference in reactivity is indirectly related to the higher minimum specified content of silica, alumina, and iron oxide for Class $F(\geq 70 \mathrm{wt} \%$ ) compared with Class $\mathrm{C}$ ( $\geq 50 \mathrm{wt} \%$ ). Although the lime content is not specified in the standard, a large fraction of the remaining composition is "free lime," which can lead to hydraulic cementitious reactions within the fly ash. Typically, the low lime content of Class F fly ash is quickly consumed, leaving the bulk of the fly ash relatively inert until caustically activated (e.g., by mixing with cement and the subsequent production of lime from hydration). Class $\mathrm{C}$ fly ash can contain lime concentrations as high as $30 \mathrm{wt} \%$ or higher, a highly reactive mix that can set into a cementitious product in a matter of minutes upon mixing with water (flash set). Since the lime content is not specified by the standard, the fly ash-lime content varies from source to source and can vary from batch to batch. For these reasons, ASTM Class F fly ash was selected for this study. 


\subsection{INDIAN RED POTTERY CLAY}

Over the years, illite (IRPC), $(\mathrm{OH})_{4} \mathrm{~K}_{x}\left(\mathrm{Al}_{4} \mathrm{Fe}_{4} \mathrm{Mg}_{4} \mathrm{Mg}_{6}\right)\left(\mathrm{Si}_{8-x} \mathrm{Al}\right) \mathrm{O}_{20}$, has become a proven standard additive in grout formulation development at ORNL for making cementitious waste forms more resistant to the leaching of ${ }^{137} \mathrm{Cs} .{ }^{25,26,29-31}$ Illite has been known as an effective selective sorbent for ${ }^{137} \mathrm{Cs}$ for decades. ${ }^{32-34}$ The gap between illite layers is apparently ideal for allowing cesium ions to diffuse between the clay layers and essentially irreversibly trap these ions. Although there are other illitic sources (e.g., conasauga shale), IRPC is the most readily available commercial source. The standard recipe evolved into $8 \mathrm{wt} \%$ of IRPC in the dry blend of cementitious materials used to stabilize/solidify the waste liquids, solids, or sludges. The $8 \mathrm{wt} \%$ in the dry blend far exceeded the stoichiometric amount needed to load the typical ${ }^{137} \mathrm{Cs}$ contamination found in the wastes into the clay because even a waste with high gamma activity from ${ }^{137} \mathrm{Cs}$ has a quite low concentration of ${ }^{137} \mathrm{Cs}$ on a molar basis. The main reason for $8 \mathrm{wt} \% \mathrm{IRPC}$ in the dry blend was to distribute enough IRPC throughout the waste form so that all the ${ }^{137} \mathrm{Cs}$ had access to the IRPC and mass transport distances were minimized. This strategy has served well for many years, as indicated by the high ANSU/ANS-16.1 leachability indexes reported for ${ }^{137} \mathrm{Cs}$ over the years for grouts containing IRPC.

\subsection{GROUND GRANULATED BLAST FURNACE SLAG}

Blast furnace slag is a normal by-product of the iron and steel industry. In general, the slag is cooled in two ways - air cooling and water quenching (granulation). Air cooling produces inert crystalline slag useful as an inert fill material but useless as a cement substitute. The essential components of slag are the same oxides as those present in portland cement, but “... for use as a cement, rapid cooling is necessary to quench the material to form a reactive glass and to prevent the crystallization of unreacted chemical compounds." Granulated slag hydrates slowly on contact with water but is activated by caustics (e.g., calcium hydroxide or sodium hydroxide), calcium sulfate, sodium carbonate, and sodium sulfate. ${ }^{9}$ The granulated slag is finely ground and marketed as a substitute for cement. The ground granulated blast furnace slags "... have physical properties similar to those of ordinary Portland cements. The distribution of particle size and the surface area of blast-furnace slags depend on the method of manufacture, but in general their fineness is similar to that of Portland cements."

Slags have been substituted for cement for decades ${ }^{36}$ Slags hydrate slowly to form $\mathrm{CSH}$, the same product formed by cements, but slag alters the morphology and properties of the final product, sometimes in subtle ways but beneficially in general: $:^{9,36-39,40-43}$

- slower early strength development,

- lower heats of hydration,

- improved sulfate resistance,

- lower permeability despite increased total porosity,

- improved frost resistance,

- lower ionic diffusion rates,

- increased salt stability,

- reduced setting rate, 
- extended working time,

- pore water contains sulfur species in addition to hydroxide anions,

- high $\mathrm{pH}$ and low oxygen potential,

- reduced solubility of most contaminants,

- reduced rate of corrosion of steel containers, and

- other physical and mechanical properties similar to portland cements (e.g., density and compressive strength).

A slag:cement combination of $75: 25$ virtually eliminates calcium hydroxide as a hydration product (i.e., the presence of excess slag prevents buildup of this cement hydration product). ${ }^{9}$ This implies that the proper proportion of slag-cement can replace cement-fly ash to stabilize ${ }^{90} \mathrm{Sr}$. In addition, a combination of 85:15 or higher slag produces a strong reducing environment within the matrix, suitable for reducing pertechnetates or chromates. ${ }^{44,45}$ Thus, slags have been used in grouts developed for radioactive and mixed wastes for a long time. ${ }^{4454}$

The ASTM standard specifies three strength grades of ground granulated blast furnace slag for use in concrete and mortars based on the slag activity index: ${ }^{.5}$

\begin{tabular}{ccc}
\multirow{2}{*}{ ASTM slag grade } & \multicolumn{2}{c}{$\begin{array}{c}\text { Minimum average slag } \\
\text { activity index, \% }\end{array}$} \\
\cline { 2 - 3 } & 7 days & 28 days \\
\hline 80 & $\ldots$ & 75 \\
100 & 75 & 95 \\
120 & 95 & 115
\end{tabular}

These slag grades are important for construction purposes but not necessarily for waste treatment, where strength requirements are usually minimal. The chemical properties normally present in commercially available slag are their most important property for waste treatment and are generally not specified in the ASTM standard. Perhaps the most important property regarding waste treatment measured in the standard is the air permeability or Blaine fineness, although no limits are specified. ${ }^{56}$ Finer slag usually means a lower permeability, not only in the dry slag but also in the resulting cementitious matrix. A lower permeability implies “... improved resistance to frost, lower diffusion rates of ions through the hardened cement and improved stability in the presence of salts, such as chloride and sulphate. ${ }^{, 9,42}$ Typically, portland cement has a Blaine fineness of $3000-4000 \mathrm{~cm}^{2} / \mathrm{g}$ and slag of $4000-5000 \mathrm{~cm}^{2} / \mathrm{g}$, but slag $>5000 \mathrm{~cm}^{2} / \mathrm{g}$, or even $>6000 \mathrm{~cm}^{2} / \mathrm{g}$, can sometimes be acquired. In general, the finer, the better, although it is unlikely that special requests for finer grinding is worth the additional costs. Any commercially available slag suitable as a cement substitute generally improves the matrix properties and imparts the desired properties to the final waste form. Ground granulated blast furnace slag with a Blaine fineness of $>4000 \mathrm{~cm}^{2} / \mathrm{g}$ was selected for this study. 


\subsection{WATER SORPTIVE AGENTS}

When a grout is poured and allowed to remain static, the binding and pozzolanic agents (cement, fly ash, slag) tend to settle, leaving a drainable liquid on the grout surface (phase separation, bleed water, freestanding liquid, or free water) ${ }^{57-59}$ Traditionally, two methods have been used to control this free water generation: (1) increasing the solids-to-liquid mix ratio [or inversely decreasing the liquid- (or water) to-solids ratio (W/S)] and (2) adding gel clays. Gel clays disperse in water and form a thick, stable colloidal gel when mixing stops. This prevents suspended particles, such as fly ash, cement, or slag, from settling while minimizing the dry blend added for treatment and the subsequent volume increase. The gel clays from oil field drilling fluids (muds) were adapted for this purpose in waste treatment grouts.

Water sorptive clays have been used in geotechnical applications, such as construction (slurry walls and clay caps) and drilling (drilling muds and cement mixes), for decades to resist solids segregation (suspension aid), prevent bleed water, and act as an engineered hydraulic barrier to water penetration (into a construction zone, waste disposal site, etc.). The most commonly used clay for these purposes is bentonite, sodium montmorillonite, “. . . a colloidal clay mined in Wyoming and South Dakota. It imparts viscosity and thixotropic properties to fresh water by swelling to about 10 times its original volume. Bentonite (or gel) was one of the earliest additives in oilwell cements to decrease slurry weight and to increase slurry volume. ${ }^{160,61}$ The individual clay particles of bentonite are plate shaped. The particle faces are positively charged, while the edges are negatively charged. When mixed with water, the platelets separate and disperse throughout the fluid. When mixing ceases, the clay particles form a multilayered colloidal gel structure due to the attraction of opposite charges. However, the electrostatic double-layer forces are lessened with increasing ionic strength ${ }^{59,62}$ Consequently, high-salt solutions (notably chloride, sulfate, and phosphate salts, as well as acids and bases) collapse these gels, lessening their dispersive effectiveness and releasing the large volume of water collected around the clay particles (i.e., free water can form if salt solutions are grouted). ${ }^{59,63}$

This susceptibility compromised the use of bentonite in off-shore oil drilling in salty waters. For this reason, attapulgite was adapted as the gel clay used in such salty applications, because attapulgite clay particles carry no charge and are not affected by high salt content..$^{59}$ The individual attapulgite particles resemble needles, rather than platelets. When mixed with water, these needles are dispersed throughout the fluid and become aligned along shear planes. When mixing ceases, a gel structure is formed by the random entanglement of these particles, referred to as a "brush-heap effect." Attapulgite is commercially available only from northern Florida and southern Georgia. ${ }^{59}$ Thus, attapulgite has been adopted as the gel clay of choice for salty wastes. Note that although several forms of attapulgite have been tested for Department of Energy (DOE) salty wastes, only attapulgite 150 (Attagel 150 ) proved effective. ${ }^{59,64}$

The American Petroleum Institute (API) has issued specifications for both bentonite and attapulgite..$^{65,66}$

In general, the hazardous waste industry adopted a different strategy for treatment of low solids wastes (i.e., wastewaters and watery sludges), although clays were not eschewed. Practically any water sorptive agent was considered a candidate, but sodium silicate may have been the most 
popular, resulting in numerous patents. ${ }^{8}$ Sodium silicate forms a hydrogel, a three-dimensional polymeric structure incorporating up to $90 \%$ water; that is, a little sodium silicate can accommodate a lot of water. Adding sodium silicate to the grout can be quite effective in controlling free water generation and generally results in a grout with a smooth surface sheen appearance, as opposed to the usual rough wet-paste appearance. Sodium silicate does thicken immediately upon mixing with cement. For this reason, it may be added as the last step in mixing to prevent any mixing problems. Hydrogels are subject to frost or dessication damage, not unexpectedly with such a large water content, so care should be exercised about using hydrogels if the waste form will be stored aboveground (or above the frost line) and/or exposed to freezing or drying conditions.

Another cheap, water sorptive bulking agent is perlite. "Perlite is a volcanic material that is mined, crushed, screened, and expanded by heat to form a cellular product of extremely low bulk weight." ${ }^{160}$ Water is absorbed by capillary action within the large volume of pore structure within this light, porous product.

In summary, the water sorptive agents selected for testing were bentonite, attapulgite, and perlite.

\subsection{SELECTING GROUT COMPOSITION FOR EVALUATION}

The initial basis for a dry blend that was developed in FY 1996 was the cement-fly ash dry blends historically used for treatment of radioactive wastes"1

\begin{tabular}{lcc} 
& \multicolumn{2}{c}{ wt \% } \\
\cline { 2 - 3 } & Hydrofracture $^{a}$ & Hanford $^{b}$ \\
\hline Type I portland cement & 42 & 38 \\
Class F fly ash & 34 & 39 \\
Attapulgite 150 drilling clay & 16 & 15 \\
IRPC & 8 & 8 \\
\hline
\end{tabular}

${ }^{a}$ Hydrofracture refers to a waste disposal strategy developed for and applied to ORNL tank sludges during the 1960s, 1970s, and early 1980s. Basically, the technique consisted of drilling a deep well into local impervious shale, horizontally hydrofracturing the shale locally at depth, and injecting a "pancake" of grouted sludge into the fractured space. ${ }^{29}$

${ }^{b}$ Hanford refers to the Hanford Grout Program, whose strategy was to mix the low-level supernate wastes stored in the Hanford tanks into a grout that was pumped into large concrete vaults. This Hanford Grout Program was canceled. ${ }^{58}$ 
Typically, a mix ratio of 0.84 and $0.72 \mathrm{~kg}$ dry blend/L waste ( 7 and $6 \mathrm{lb}$ dry blend/gal waste) was tested for these two applications. ${ }^{29.58}$ Assuming a waste specific gravity of about $1.2(10 \mathrm{lb} / \mathrm{gal})$, these mix ratios give waste loadings of about $60 \mathrm{wt} \%$. Thus, strong monoliths can be expected at waste loadings up to $60 \mathrm{wt} \%$, although some problems with bleed water may be experienced, depending on the water content of the waste and the steps taken to control bleed water. Note that approximately equal proportions of cement-fly ash were used with $8 \mathrm{wt} \%$ IRPC. These two grouts were developed for low solids wastes, and the need for a large fraction of water sorptive agent in the dry blend was uncertain a priori for the present tank sludge application (the goal was to develop a grout for the sludge interstitial water content as it rests in the tanks, ignoring retrieval or pretreatment requirements). Hence, the water sorptive content was varied, dropping to zero, but increased as needed, depending on the agent and performance. In addition, slag replaced cement as the binder of choice. Cement was included to activate the slag, but a slag:cement combination of about 90:10 was maintained to enhance the reducing capability of the matrix. In general, IRPC was fixed at $8 \mathrm{wt} \%$ in the dry blend for ${ }^{137} \mathrm{Cs}$ stabilization. The fly ash was kept as a proven pozzolan for ${ }^{90} \mathrm{Sr}$ stabilization. (The main mobile radionuclides of interest in these tank sludges are ${ }^{137} \mathrm{Cs}$ and ${ }^{90} \mathrm{Sr}$.) The fly ash content was allowed to float to compensate for the varying content of water sorptive agent.

Thus, the dry blend formula used to initiate experimental work in FY 1996 is as follows: ${ }^{1}$

\begin{tabular}{lr} 
& wt \% \\
\hline Slag-Type I-II portland cement (90:10) & $40-50$ \\
Class F fly ash & $25-50$ \\
Water sorptive agent & $0-20$ \\
IRPC & 8
\end{tabular}

A robust dry blend was developed in FY 1996 for the surrogate MVST/BVEST sludge and was used as the basis for the work reported in this document. The composition of this dry blend follows: ${ }^{1}$

wt \%

Ground granulated blast furnace slag

Type I-II portland cement

Class F fly ash

Perlite

IRPC 


\section{SURROGATE LABORATORY STUDIES}

\subsection{EXPERIMENTAL}

\subsubsection{Surrogate Preparation}

The surrogate wet sludges were prepared from reagent-grade chemicals according to the compositions listed in Table 1 . The chemicals were allowed to hydrolyze by mixing with the recipe water at least $20 \mathrm{~min}$.

\subsubsection{Blending}

The dry blends, which were then mixed with the surrogate wet sludge to make grouts, consisted of blends of two or more of the following dry powders: (1) ground granulated blast furnace slag (slag) with a Blaine fineness of $6220 \mathrm{~cm}^{2} / \mathrm{g}$ from the Koch Minerals Co., (2) Type I-II Portland cement (cement) from the Dixie Cement Co., (3) Class F fly ash (fly ash) from the American Fly Ash Co., (4) Grade H-200 perlite from the Harborlite Corp. (perlite), (5) IRPC from the American Art Clay Co., (6) Attapulgite 150 ground clay (attapulgite) from the Engelhardt Corp., and (7) bentonite clay (bentonite) from the Benton Clay Co. The dry blends were blended for $2 \mathrm{~h}$ in an 8-qt twin-shell blender (or V-blender) from the Patterson-Kelley Co.

\subsubsection{Mixing}

The grouts were mixed in a Model N-50 Hobart mixer using a flat blade. The surrogate wet sludge was added to the Hobart bowl first, then the dry blend was added to the sludge while mixing on low speed (30-60 s). The grout was then mixed on low speed for 2 min and medium speed for $2 \mathrm{~min}$, cast into containers or molds for performance testing, and cured. The procedure for spiking with radionuclides for making leach samples consisted of adding the spike to the wet sludge in the Hobart bowl, mixing on low speed for $20 \mathrm{~min}$, then adding the dry blend using the above procedure.

\subsubsection{Curing}

The freshly made grout was stored in a humidity cabinet and cured in a humid environment at room temperature. The samples were cured only $7 \mathrm{~d}$ for the scope testing, but the standard was cured $28 \mathrm{~d}$ for the sensitivity testing.

\subsubsection{Performance Testing}

The performance tests for the scope testing consisted of measuring the density, the penetration resistance, free water (or bleed water), and TCLP performance after only $7 \mathrm{~d}$. The sensitivity testing consisted of measuring the density, 28-d unconfined compressive strength, 28- $\mathrm{d}$ free water, 28-d TCLP performance, and the 28-d leachability index of ${ }^{85} \mathrm{Sr}$ and ${ }^{137} \mathrm{Cs}$. 
The free water was measured by casting $250 \mathrm{~mL}$ of grout into a graduated cylinder and measuring the volume of free water standing over the solid grout. This property is reported as vol\%, calculated by dividing the observed free water volume in $\mathrm{mL}$ by $250 \mathrm{~mL}$ and multiplying by 100 .

The density of the freshly mixed grout was obtained by measuring the net mass in $\mathrm{g}$ of the $250 \mathrm{~mL}$ of grout in the free water test and dividing by $250 \mathrm{~mL}$ to obtain the density in units of $\mathrm{g} / \mathrm{mL}$.

For penetration resistance, the force $\left(\mathrm{lb}_{\mathrm{f}}\right)$ required to push a flat rod with a cross-sectional area of $1 / 40$ in. $^{2}$ a preset distance into the partially cured grout was measured. This force was divided by the cross-sectional area and reported as penetration resistance (psi). The pressure gauge on the penetrometer reads a maximum pressure of $200 \mathrm{lb}_{\mathrm{f}}$, limiting measurements on penetration resistance to $8000 \mathrm{psi}$. The penetration resistance can be measured at any time after mixing, once the grout begins to harden. Measurements were routinely taken at $7 \mathrm{~d}$ but were optionally taken at shorter intervals, such as $1 \mathrm{~d}$.

For the unconfined compressive strength, nominal 2-in. cubes of grout were cast and cured. After curing $28 \mathrm{~d}$, the cube dimensions were measured and the force $\left(\mathrm{lb}_{\mathrm{f}}\right)$ required to crush the cube measured on a Tinius-Olsen Machine. Dividing the crushing force by the cube cross-sectional area gave the unconfined compressive strength (psi).

A modified TCLP test was performed for this study. The modified procedure extracts a $10 \mathrm{-g}$ sample with $200 \mathrm{~mL}$ of extractant, rather than the standard $200-\mathrm{g}$ sample with $2 \mathrm{~L}$ of extractant. The TCLP test uses one of two extractants: (1) an acetic acid solution with sodium hydroxide added (TCLP Extraction Fluid No. 1, pH of about 4.9) or (2) the straight acetic acid solution (TCLP Extraction Fluid No. 2, pH of about 2.9). (The procedure dictates which extractant to use based on the buffering capability of the sample when mixed with a hydrochloric acid solution.) After extracting $18 \mathrm{~h}$, the undissolved solids are filtered from the extract and the extract is digested using a microwave digester. The concentrations of the inorganic RCRA metals, except mercury, in the extract were then measured using a Thermo Jarrel Ash Inductively Coupled Argon Plasma 61E Tracer Analyzer (TJA 61E trace ICP). Although selenium and arsenic analyses by ICP are not usually accepted, EPA accepts the higher sensitivity of the 61E. The concentration of mercury in the TCLP extract was measured using a Leeman Labs PS 200 cold vapor atomic absorption (CVAA) mercury analyzer.

For the leachability index, a semidynamic leach test was performed using a modification of the ANSUANS-16.1 test. (In a semidynamic test, the samples remain quiescent in the leachate for a set time interval and are then moved to a fresh leachate at zero concentration for the next time interval.) The grout samples were leached in deionized water. The concentration of the radionuclides were measured by gamma spectroscopy using a germanium detector with an efficiency of $10 \%$ and a background of 30 counts per $1000 \mathrm{~s}$ or 0.03 counts per second (cps). After a 30-s rinse, the leachates were changed at cumulative times of $1,2,3,4$, and $7 \mathrm{~d}$. The effective diffusion coefficient was estimated from the cumulative fraction leached with time, assuming diffusion-controlled leaching. The leachability index is the negative of the logarithm of the effective diffusion coefficient. 


\subsection{OVERALL WEIGHTED AVERAGE SURROGATE SLUDGE RESULTS}

The experimental work consisted of two phases: scope testing and sensitivity testing. The scope testing explored the waste form behavior for a limited set of performance tests over a range of compositions to establish an envelope of acceptable waste form compositions. After establishing this envelope, an acceptable formulation, identified as $60 \mathrm{WL}$ in each table of screening tests, was selected for testing the sensitivity of the formulation to variations in the formulation and surrogate composition.

\subsubsection{Scoping Tests}

Table 2 lists the compositions tested during the screening tests with the overall surrogate sludge. Table 3 lists the free water and penetration resistance results for these grouts, and Table 4 lists the TCLP results. Table 5 lists the grout density and the grout/sludge volume ratio calculated from the sludge loading, sludge density, and grout density. The density measured for the standard surrogate sludge is also listed in Table 5 . The surrogate sludge density at different sludge water contents was calculated using additive volumes from the measured density of the standard surrogate and assuming a water density of $1.0 \mathrm{~g} / \mathrm{mL}$.

The first series, O1-O7, tested variations in the water sorptive agent and wet sludge loading in the grout formulation. Figures 1 and 2 illustrate that the samples with the higher sludge loadings had free water present and produced weaker products, just as with the MVST/BVEST surrogate sludge in FY 1996. This grout formulation is fairly robust at a wet sludge loading of $55 \mathrm{wt} \%$, with the following three variations working effectively: no water sorptive agent, prehydrated bentonite, and perlite. Only attapulgite did not effectively control the free water at this sludge loading. Figure 3 illustrates the range of W/S tested in this initial series with varying wet sludge loading at a constant water content for the overall surrogate sludge.

The observation that free water performance limits the wet sludge loading and that free water was a function of W/S led to the second series of tests, OA1-OA7. In these tests, the wet sludge loading varied from $60-90 \mathrm{wt} \%$ while holding the W/S constant at 0.5 . These tests imply a field operation that dewaters the sludge within prescribed limits to meet the free-water performance criterion. Figure 4 illustrates how higher sludge loadings can be achieved with this strategy, at the cost of grout strength.

Similarly, the series OB1-OB8 demonstrate the robustness of the perlite dry blend at $60 \mathrm{wt} \%$ wet sludge loading over a range of W/S of $0.48-0.65$. Figure 5 illustrates acceptable free water and penetration resistance performance within $7 \mathrm{~d}$ for these grouts. Figure 6 illustrates how these grouts set within $7 \mathrm{~d}$ and reabsorb the free water that initially appears.

Figure 7, for series OC1-OC6, illustrates that the perlite content of the dry blend can be reduced from $20 \mathrm{wt} \%$ to $10 \mathrm{wt} \%$ without sacrificing performance. Series OD1-OD4 tested replacing perlite with attapulgite and determined whether shearing the attapulgite improved its water sorptive performance. Figures 8 and 9 illustrate that shearing the attapulgite improved the water sorptive performance, such that no free water was present after $7 \mathrm{~d}$, with wet sludge loadings as high as $60 \mathrm{wt} \%$. 
A final series of tests, OF1-OF11, was run at different W/S for wet sludge loadings of $65-75 \mathrm{wt} \%$. Figure 10 illustrates the performance for the robust dry blend at these sludge loadings.

Reviewing the TCLP results for the overall screening grouts listed in Table 4, (1) the surrogate sludge was characteristically hazardous for chromium and mercury, (2) the treated surrogate sludge (the grouts) routinely passed the Universal Treatment Standards (UTS) for all the RCRA metals except chromium, (3) the treated surrogate sludge was not characteristically hazardous for chromium, and (4) the treated sludge did not always meet UTS limits for chromium above $70 \mathrm{wt} \%$ wet sludge loading, as illustrated in Fig. 11. This limit on sludge loading to stabilize chromium may be an artifact of conservatively using the soluble sodium dichromate in the surrogate sludge, whereas the few TCLP tests performed on actual ORNL tank sludges reportedly fail only for mercury, not chromium. These results imply that the large chromium contents measured in these tank sludges are relatively insoluble and that the chromium is likely present as $\mathrm{Cr}$ (III), as opposed to $\mathrm{Cr}(\mathrm{VI})$. Nevertheless, these results imply the limits of this dry blend for reducing and stabilizing soluble chromates (i.e., $<70 \mathrm{wt} \%$ wet sludge loading contaminated with $677 \mathrm{mg} / \mathrm{kg}$ of sodium dichromate or $<475 \mathrm{mg} / \mathrm{kg}$ in the final grout).

As shown in Table 4, grouting resulted in a volume increase of 5-50 vol \% for surrogate overall sludge loadings of 55-90 wt \%.

Based on these screening test results, the dry blend listed as $60 \mathrm{WL}$ in Table 2 at a wet sludge loading of $60 \mathrm{wt} \%$ was selected for the sensitivity testing.

\subsubsection{Sensitivity Testing}

The scoping tests were used to test candidate grout formulations and to select one as a potential candidate for grouting the tank sludge. Sensitivity testing is the evaluation of the sensitivity of this selected formulation to changes in waste composition and changes in concentration of the grout ingredients. The dry blend selected for sensitivity testing consisted of 33,20,19,20, and $8 \mathrm{wt} \%$ slag, cement, fly ash, perlite, and IRPC, respectively. This dry blend was limited to a sludge loading of $60 \mathrm{wt} \%$, because of the free water criteria. The standard grout composition resulting from this formulation is listed as Grout \#1 in Table $6 . \mathrm{A} \pm 10 \%$ variation in formulation was chosen as the basis for the sensitivity testing. A subset of four variations in formulation, among all the possible variations, was selected for this sensitivity test. Table 6 also lists these four grouts selected for sensitivity testing. The sensitivity testing also consisted of testing the variation in sludge composition possible in the tank sludges. Thus, the standard grout and four formulation variations were tested with the standard surrogate sludge. To test any possible effects of variation in sludge composition, the standard grout formulation was also tested with surrogate sludge at the maximum water content (from previous characterization data) and with surrogate sludge at the minimum water content and the maximum concentration of bad actors from previous characterization data). (The bad actors were defined as the RCRA metals, sulfate, halides, carbonate, phosphate, and tributylphosphate.) Table 7 lists the three surrogate sludge compositions used in the sensitivity testing of the overall surrogate sludge for the ORNL tank sludges. 
Tables 8-12 list the following results for the sensitivity testing of the overall grouts: grout density, grout/sludge volume ratio, and consistency, free water, unconfined compressive strength, TCLP performance, and cesium and strontium leachability indexes.

The standard grout (Grout No. 1) had a density of 1.61, a volume increase of $36 \mathrm{vol} \%$, good consistency, no free water after $7 \mathrm{~d}$, an average compressive strength of $1156 \mathrm{psi}$, an acceptable TCLP performance, and cesium and strontium leachability indexes $>10.0$. The variation in grout and surrogate composition made the density vary from 1.39 to $1.65 \mathrm{~g} / \mathrm{mL}$ and the volume increase vary from 28 to $54 \mathrm{vol} \%$. Although the composition variations affected the appearance of free water during cure and the rate at which the free water disappeared, none of the composition variations had any free water after curing $7 \mathrm{~d}$, except Grout No. 1 made with the surrogate sludge with maximum water ( $89.0 \mathrm{wt} \%$ water in the wet sludge). The composition variations significantly affected the compressive strength, ranging from 784 to 2723 psi, but all were $>500$ psi. The dry blend composition variations with the standard surrogate sludge had little effect on the TCLP performance, and all extract concentrations were below the limiting values for RCRA characteristically hazardous, TCLP LDR, or UTS. On the other hand, the surrogate sludge with the minimum water content and maximum bad actor concentrations resulted in measurable TCLP extract concentrations for several RCRA metals and, for chromium and mercury, an extract concentration equal to or slightly greater than the UTS limit. The composition variations had little effect on the leachability indexes.

\subsection{GAAT SURROGATE SLUDGE RESULTS}

The experimental work consisted of two phases: scope testing and sensitivity testing. The scope testing explored the waste form behavior for a limited set of performance tests over a range of compositions to establish an envelope of acceptable waste form compositions. After establishing this envelope, an acceptable formulation, identified as $60 \mathrm{WL}$ in each table of screening tests, was selected for testing the sensitivity of the formulation to variations in the formulation and surrogate composition.

\subsubsection{Scoping Tests}

Table 13 lists the grout compositions tested during the screening tests using the GAAT surrogate sludge. Table 14 lists the free water and penetration resistance results for these grouts, and Table 15 lists the TCLP results for these grouts. Table 16 lists the grout density and the grout/sludge volume ratio calculated from the sludge loading, sludge density, and grout density. The density measured for the standard surrogate sludge is also listed in Table 16. The surrogate sludge density at different sludge water contents was calculated using additive volumes from the measured density of the standard surrogate and assuming a water density of $1.0 \mathrm{~g} / \mathrm{mL}$.

Figure 12 illustrates the free water and penetration resistance performance for this series of grouts, GAAT1-GAAT14. As with the overall surrogate sludge, the tendency to form free water increases and the grout strength decreases as the sludge loading increases at a constant sludge water content (meaning the W/S increases with loading). Also, similarly, maintaining a constant W/S allows higher sludge loadings without free water. 
The TCLP performance was similar to the screening test results for the overall surrogate sludge. The surrogate sludge was characteristically hazardous for chromium and mercury. For the grout samples, the sodium dichromate in the surrogate sludge produced leachate concentration higher than the TCLP limit at the higher sludge loadings ( $>80 \mathrm{wt} \%$ for the surrogate GAAT sludge).

As shown in Table 16, grouting resulted in a volume increase of $11-46$ vol \% for surrogate GAAT sludge loadings of 55-90 wt \%.

Based on these screening test results, the dry blend listed in 60WL in Table 13 at a wet sludge loading of $60 \mathrm{wt} \%$ was selected for the sensitivity testing. The same grout formulation was seleted as the basis for the sensitivity grout testing for the average and GAAT surrogates.

\subsubsection{Sensitivity Testing}

Sensitivity testing is the evaluation of the sensitivity of a selected formulation to changes in waste composition and changes in concentration of the grout composition. The dry blend selected for sensitivity testing consisted of 33,20,19,20, and 8 wt \% slag, cement, fly ash, perlite, and IRPC, respectively. This dry blend was limited to a sludge loading of $60 \mathrm{wt} \%$, because of the free water criteria. The standard grout compositions resulting from this formulation are listed as Grout \#1 in Table $6 . \mathrm{A} \pm 10 \%$ variation in formulation was chosen as the basis for the sensitivity testing. A subset of four variations in formulation, among all the possible variations, was selected for this sensitivity test. Table 6 also lists these four grouts selected for sensitivity testing. The sensitivity testing also consisted of testing the variation in sludge composition possible in the tank sludges. Thus, the standard grout and four formulation variations were tested with the standard surrogate sludge. To test any possible effects of variation in sludge composition, the standard grout formulation was also tested with surrogate sludge at the maximum water content (from previous characterization data) and with surrogate sludge at the minimum water content and the maximum concentration of bad actors (from previous characterization data). Table 17 lists the three surrogate sludge compositions used in the sensitivity testing of the GAAT surrogate sludge for the ORNL tank sludges.

Tables 18-22 list the following results for the sensitivity testing of the GAAT grouts: grout density, grout/sludge volume ratio, consistency, free water, unconfined compressive strength, TCLP performance, and cesium and strontium leachability indexes.

The standard grout (Grout No. 1) had a density of 1.53 , a volume increase of $35 \mathrm{vol} \%$, good consistency, no free water after $1 \mathrm{~d}$, an average compressive strength of $727 \mathrm{psi}$, an acceptable TCLP performance, and cesium and strontium leachability indexes $>10.0$. The variation in grout and surrogate composition made the density vary from 1.48 to $1.66 \mathrm{~g} / \mathrm{mL}$ and the volume increase vary from 29 to $43 \mathrm{vol} \%$. None of the GAAT sensitivity grouts exhibited free water after $1 \mathrm{~d}$. The composition variations significantly affected the compressive strength, ranging from 393 to 1398 psi. Although the unconfined compressive strength of the standard formulation (Grout No. 1) exceeded 500 psi, some variations in the dry blend composition did result in average unconfined compressive strengths $<500 \mathrm{psi}$. The dry blend composition variations with standard surrogate sludge had little effect on the TCLP performance and all extract concentrations were below the limiting values for RCRA characteristically hazardous, TCLP 
LDR, or UTS. On the other hand, the surrogate sludge with the minimum water content and maximum bad actor concentrations resulted in a chromium extract concentration well above the UTS limit. The composition variations had little effect on the leachability indexes.

\subsection{OHF SURROGATE SLUDGE RESULTS}

The experimental work consisted of two phases: scope testing and sensitivity testing. The scope testing explored the waste form behavior for a limited set of performance tests over a range of compositions to establish an envelope of acceptable waste form compositions. After establishing this envelope, an acceptable formulation, identified as $60 \mathrm{WL}$ in each table of screening tests, was selected for testing the sensitivity of the formulation to variations in the formulation and surrogate composition.

\subsubsection{Scoping Tests}

Table 23 lists the grout compositions for the surrogate OHF sludge. Tables 24 and 25 list the free water and penetration resistance test results and the TCLP test results for these grouts. Table 26 lists the grout density and the grout/sludge volume ratio calculated from the sludge loading, sludge density, and grout density. The densities measured for the standard surrogate sludge and the surrogate sludge with thorium nitrate substituting for thorium oxide are also listed in Table 26. The surrogate sludge density at different sludge water contents was calculated using additive volumes from the measured density of the standard surrogate and assuming a water density of $1.0 \mathrm{~g} / \mathrm{mL}$.

In the series OHF1A-OHF4A, the robust dry blend was tested with a surrogate that substituted thorium nitrate for thorium oxide. The series OHF1-OHF4 tested the same grouts using the standard surrogate OHF sludge listed in Table 1 (i.e., with thorium oxide). Although the surrogate using thorium nitrate behaved similarly to the previous surrogate sludges tested with the robust dry blend, the standard surrogate OHF sludge with thorium oxide did not in that these grouts remained soft and did not appear to set. Figure 13 illustrates this atypical behavior, with the grouts made from the thorium nitrate surrogate showing the typical declining penetration resistance with loading while the thorium oxide surrogate grouts exhibit no penetration resistance within $7 \mathrm{~d}$ except at the highest sludge loading.

Decreasing the perlite content appeared to counteract this atypical behavior, as illustrated in Fig. 14 for the series OHF5-OHF8, but another key appeared to be the apparent lower pH for the standard surrogate OHF sludge. Sodium hydroxide was added to increase the surrogate $\mathrm{pH}$ and help activate the high slag dry blend. Adding the sodium hydroxide allowed use of the same robust dry blend with $20 \mathrm{wt} \%$ perlite and increased the sludge loading from $55 \mathrm{wt} \%$ to $60 \mathrm{wt} \%$.

As with the TCLP performance for the other surrogate sludges, the OHF surrogate sludge was characteristically hazardous for chromium and mercury and proved difficult to stabilize (regarding sodium dichromate) at the higher sludge loadings (e.g., $68 \mathrm{wt} \%$ ) of the standard surrogate OHF sludge. 
From Table 26 , grouting resulted in a volume increase of $24-42$ vol $\%$ for surrogate OHF sludge loadings of 55-68.3 wt \%.

Based on these screening test results, the dry blend listed in 60WL in Table 23 at a wet sludge loading of $60 \mathrm{wt} \%$ was selected for the sensitivity testing. In general, this grout formulation was considered robust enough to use as the basis for the sensitivity grout testing for the Overall, GAAT, and OHF surrogates.

\subsubsection{Sensitivity Testing}

Sensitivity testing is the evaluation of the sensitivity of a selected formulation to changes in waste composition and changes in concentration of the grout composition. The dry blend selected for sensitivity testing consisted of 33,20,19,20, and $8 \mathrm{wt} \%$ slag, cement, fly ash, perlite, and IRPC, respectively. This dry blend was limited to a sludge loading of $60 \mathrm{wt} \%$, because of the free water criteria. The standard grout compositions resulting from this formulation are listed as Grout \#1 in Table $6 . \mathrm{A} \pm 10 \%$ variation in formulation was chosen as the basis for the sensitivity testing. A subset of four variations in formulation, among all the possible variations, was selected for this sensitivity test. Table 6 also lists the four grouts selected for sensitivity testing. The sensitivity testing also consisted of testing the variation in sludge composition possible in the tank sludges. Thus, the standard grout and four formulation variations were tested with the standard surrogate sludge. To test any possible effects of variation in sludge composition, the standard grout formulation was also tested with surrogate sludge at the maximum water content (from previous characterization data) and with surrogate sludge at the minimum water content and the maximum concentration of bad actors (from previous characterization data). (The bad actors were defined as the RCRA metals, sulfate, halides, carbonate, phosphate, and tributylphosphate.) Table 27 lists the three surrogate sludge compositions used in the sensitivity testing of the OHF surrogate sludge for the ORNL tank sludges.

Tables 28-32 list the following results for the sensitivity testing of the OHF grouts: grout density, grout/sludge volume ratio, consistency, free water, unconfined compressive strength, TCLP performance, and cesium and strontium leachability indexes.

The standard grout (Grout No. 1) had a density of 1.61, a volume increase of 35 vol \%, a fluid consistency, $0.4 \mathrm{vol} \%$ free water after $28 \mathrm{~d}$, an average compressive strength of $508 \mathrm{psi}$, an acceptable TCLP performance, and cesium and strontium leachability indexes $>11.0$. The variation in grout and surrogate composition made the density vary from 1.55 to $1.65 \mathrm{~g} / \mathrm{mL}$ and the volume increase vary from 28 to $43 \mathrm{vol} \%$. Only one of the OHF sensitivity grouts (Grout No. 5) exhibited no free water after 7 or $28 \mathrm{~d}$. The composition variations significantly affected the compressive strength, ranging from 363 to 903 psi. Although the unconfined compressive strength of the standard formulation (Grout No. 1) exceeded $500 \mathrm{psi}$, some variations in the dry blend composition did result in average unconfined compressive strengths $<500 \mathrm{psi}$. The dry blend and sludge composition variations had little effect on the TCLP performance and all extract concentrations were below the limiting values for RCRA characteristically hazardous, TCLP LDR, or UTS. The composition variations had little effect on the leachability indexes. 


\subsection{TESTING PERFORMANCE FOR BERYLLIUM IN TCLP}

Although the TCLP extract concentration for beryllium is listed in the TCLP results for the screening tests (Tables 4, 15, and 25), no beryllium compound was included in the surrogate sludges except for the 60WL tests listed at the end of each table. Since prior characterization analysis had indicated some sludge samples contained enough beryllium to be of concern as an underlying hazardous constituent in the TCLP test, it was necessary to check for beryllium performance in the TCLP test at some point. However, beryllium was deemed too hazardous for routine handling in these tests, so beryllium testing was reserved for one test for each surrogate in a final test after selection of the formulation for sensitivity testing, the 60WL grouts. These grouts were prepared in the standard way, but beryllium was added with the water to give a final concentration of about $30 \mathrm{mg} / \mathrm{kg}$ of beryllium in the wet sludge for the $60 \mathrm{WL}$ grouts. The concentrations of beryllium in the TCLP extract concentrations for these grouts were 0.003 , 0.001 , and $0.001 \mathrm{mg} / \mathrm{L}$ for the overall, GAAT, and OHF surrogate sludges, respectively. These extract concentrations are well below the UTS limit of $0.014 \mathrm{mg} / \mathrm{L}$.

\subsection{EFFECT OF IRPC ON LEACHABILITY INDEX}

The IRPC is a well established additive for stabilizing ${ }^{137} \mathrm{Cs}$. Some recent results in another project for developing a grout formulation for in situ grouting of the GAAT sludges had better ${ }^{137} \mathrm{Cs}$ leachability indexes using $15 \mathrm{wt} \%$ IRPC in the dry blend as opposed to $8 \mathrm{wt} \%$. Thus, the leachability indexes for the standard grout at $60 \mathrm{wt} \%$ surrogate overall sludge was tested with IRPC in the dry blend of 0,8 , and $15 \mathrm{wt} \%$. Figure 15 illustrates the improvement in ${ }^{137} \mathrm{Cs}$ leachability index of 8.3 to 11 to 12 , respectively. The ${ }^{85} \mathrm{Sr}$ leachability index was relatively constant at 10 for all IRPC concentrations.

\section{TESTING OF W25 SLUDGE SAMPLE}

\subsection{LABORATORY TESTING OF W25 SURROGATE}

The composition of the sludge sample from MVST tank W25 was an outlier in the range of compositions used as a basis for the surrogate MVST/BVEST sludge used to develop the grout formulation in FY 1996. 'Therefore, a surrogate was developed for the W25 sample (Table 1) and tested in the laboratory prior to hot cell testing. This surrogate proved to be a high water demand sludge, much higher than the standard MVST/BVEST surrogate. The standard grout formulation developed in FY 1996 with $55 \mathrm{wt} \%$ wet sludge at $52 \mathrm{wt} \%$ water proved to be too dry and did not make a wet mixable paste. Originally, a series of tests was planned, varying the water content of the wet sludge from 45 to $80 \mathrm{wt} \%$. In the first test, $45 \mathrm{wt} \%$ proved to have too little water and water had to be added to make an equivalent wet sludge of $52 \mathrm{wt} \%$. The resulting wet paste was rather thick to work with in the laboratory and was determined to be too thick for hot cell work. Consequently, testing focused on a range of $65-85 \mathrm{wt} \%$ water in the wet sludge. Table 33 lists the results of testing the W25 surrogate with varying water contents. The 
surrogate indicates this sludge will present difficult handling problems in the standard grout; therefore, a water content of $80 \mathrm{wt} \%$ was recommended for the hot cell work.

\subsection{HOT CELL WASTEFORM PREPARATION}

\subsubsection{Waste Sludge Composition and Properties}

The surrogate sludge was formulated based upon a large amount of chemical data available on the W25 sludge. The actual W25 sludge as removed from the MVST had a density of $1.36 \mathrm{~g} / \mathrm{mL}$ and its supernate had a density of $1.2 \mathrm{~g} / \mathrm{mL}$. Upon being centrifuged at $2500 \mathrm{rpm}$ for $20 \mathrm{~min}$, and pouring off the supernate, the resulting sludge used in this experimental work had a bulk density of $1.52 \mathrm{~g} / \mathrm{mL}$. This sludge, when used to prepared cement-based grout, had water added to it to obtain $80 \mathrm{wt} \%$. Sludge with a high water content be encountered after sluicing or other removal operations, which may add water. Formulation studies performed with surrogate showed that this sludge water content was acceptable based upon compressive strength, TCLP tests, workability, and the absence of bleed water. Additionally, the ability to fully hydrate the dry solids and also remain fluid during mixing necessitated water addition. Since the W25 sludge has been used in a number of studies, a large amount of data is available on it. Table 34 lists the composition measured in a W25 sample. ${ }^{67}$ The chemical composition of the surrogate sludge is presented in Table 35.

\subsubsection{Equipment and Setup}

A walk-in hot cell equipped with manipulators was decontaminated and set up for dedicated use in the preparation of both cement-based and vitreous waste forms. The cell, designated as cell D, is located in a complex of four walk-in cells in Building 4501 at ORNL. Figure A.1 is a photograph of the front of the cell, as presented in the appendix. The interior of the cell is 6 by 9 by $16 \mathrm{ft}$ in height and is designed for easy entry.

\subsubsection{Grouting Studies with W25 Surrogate and Actual Tank Sludge}

6.2.2.1.1 Modification of the Hobart Mixing Equipment. Standard equipment normally used for the preparation of cement-based grouts had to be modified for use with manipulators within the confines of the hot cell. A standard Hobart mortar mixer was modified by placing an enclosure over the mixing bowl with two tubes located above for placing dry solids and waste inside without forming too much dust that might spread contamination. Additionally the base of the mixer was modified such that it stood approximately 6 in. higher so that the mixing bowl could be removed more easily using manipulators. When mixing was in progress, the mixer was completely covered to eliminate possible cell contamination from the dry solids component of the grout. The bowl and enclosure locked against each other by way of a rubber gasket seal.

The mixer was operated with a wire wisk-type blade. A special tool was designed to remove this blade without contaminating the manipulator hand and working area. The modified Hobart mixer and tool are shown in the appendix in Fig. A.2. 
6.2.2.1.2 Funnel and Cylinder Setup. Since bleed water formation was of interest, a means for placement of grout slurry into a plastic cylinder was devised for use in the cell. This seemingly simple task was significantly more complex since it had to be performed remotely. A stainless steel funnel with "all-thread" adjustable legs and pickup grips attached was fabricated such that it could fit inside the top of the cylinder. The mixer pot was locked above the funnel, and the slurry was scraped into the cylinder using a plastic cake spatula. After the cylinder had received enough of the slurry, the cylinder was placed on a vibratory mixer to settle the slurry and remove any pockets where potential bleed water could be trapped. After the slurry had settled and was free of visible voids, the plastic cylinder was sealed with a special plug that was molded to match the inner surface of the cylinder to prevent evaporation. This molded stopper was sealed into the cylinder by placing a layer of silicone on the plug surface. This was necessary since the cell has a very high volumetric flow of air into and out through HEPA filters and the evaporation of water was a real concern.

An additional test of interest for the cement-based grout waste form was the TCLP. In order to prepare grout for this test, grout slurry remaining inside the pot of the Hobart mixer was scraped into a plastic zip-lock, bag and the contents of the bag was flattened after sealing the bag. The flattened sample was allowed to cure for $28 \mathrm{~d}$ in this bag. After curing, the flattened grout "pancake" was broken while still in the bag using a piece of wood and extra bags. The broken pieces were screened through a 9.6-mm screen in preparation for removal from the cell and use in the TCLP test.

6.2.2.1.3 Penetration Resistance. A penetrometer with a wire penetrator tip of $1 / 40$ in. $^{2}$ was used to follow the rate of set. As the tip penetrated the grout samples, pounds force was displayed by a marker dial. Penetration resistance, which indicates the state of set, was calculated by multiplying the dial value by 40 to obtain the resistance in pounds per square inch (psi). The handle of the apparatus was modified with a swivel for the manipulator hand to allow movement forward in the confines of the hot cell. This penetrometer apparatus and modification is shown in the Fig. A. 2 in the appendix.

Forms to contain the cured grout were fabricated from 2-in. PVC pipe caps epoxied to a piece of wood. Grout slurry from the mixing pot was spooned into the caps and vibrated to remove voids. The top of the wet grout in these caps was troweled with a soft plastic cake spatula to produce a flat surface. The filled forms were placed inside a zip-lock bag along with a wetted sponge and sealed. The sponge was checked periodically to ensure it was always wet, to keep the air in the bag saturated with water vapor. After various intervals, the cap-molded apparatus was removed from the bag and placed beneath the penetrometer and the test was performed. Penetrometer readings were obtained after $1,2,3,4$ and $7 \mathrm{~d}$.

6.2.2.1.4 Cement-Based Grout Formula. A wide range of water concentrations was used in the surrogate sludge to observe variations in mixing properties and bleed water. The dry solid blend was premixed in a V-blender and placed in preweighed bottles for use in the hot cell. The dry solid blend used in the preparation of our cement-grout was as follows: 


$\begin{array}{lr}\text { IRPC } & 8.0 \% \\ \text { Perlite } & 20.0 \% \\ \text { Fly ash (Type F) } & 19.1 \% \\ \text { Blast furnace slag } & 32.9 \% \\ \text { Portland Type II cement } & 20.0 \%\end{array}$

The test work with surrogate grout utilized $661.05 \mathrm{~g}$ of surrogate sludge, as shown in Table 35 , containing $80 \%$ water, together with $540.76 \mathrm{~g}$ of the dry blend. The two were mixed for $10 \mathrm{~min}$ at low speed and $2 \mathrm{~min}$ at high speed in the Hobart mixer prior to use.

The same blending technique was utilized with the actual W25 sludge, except that since the centrifuged starting sludge contained only $50.5 \%$ water, instead of the $80 \%$ in the surrogate, water was added to achieve the desired amount of water.

The method of preparation of grout with actual tank waste included the use of $296.5 \mathrm{~g}$ of centrifuged sludge containing $50.5 \%$ water, in addition to $600.31 \mathrm{~g}$ of the dry blend and $437.34 \mathrm{~g}$ of makeup water, added as deionized water. Following the same mixing scheme and times used for the surrogate sludge, the resulting paste appeared thicker than when using the surrogate sludge.

If the grout slurry prepared with the actual waste sludge was observed to be too thick to handle, then plans were to add additional water.

\subsubsection{Cement-Based Grouts Test Results}

6.2.2.2.1 Bleed Water. Results with both the surrogate waste and the actual tank waste showed that at $24 \mathrm{~h}$ no bleed water was observed on either of the two sealed cylinders of grout. The grout slurry produced from actual sludge never formed any bleed water, while the grout slurry containing surrogate waste produced a trace which was too small to be measured and was taken up by the grout over the first several hours.

6.2.2.2.2 Penetrometer. Both the surrogate and actual waste-containing grout reached very high penetration resistances after only $7 \mathrm{~d}$. Both grouts had nearly the same penetration resistance after $24 \mathrm{~h}$; however, the grout containing actual waste quickly accelerated in strength after that time. Grout containing the surrogate waste achieved a penetration resistance of $6440 \mathrm{psi}$ at $7 \mathrm{~d}$, while that containing the actual tank sludge achieved 8400 psi. The more rapid rise in penetration resistance for grout containing the actual tank waste is shown in Table 36.

6.2.2.2.3 Toxicity Characteristic Leaching Procedure (TCLP) Test. Untreated W 25 waste sludge submitted to the TCLP test failed the test for mercury. Grout samples containing surrogate and actual tank sludge passed the TCLP test. Table 37 lists the results. 


\subsubsection{Vitrification Studies with W25 Surrogate and Actual Tank Sludge}

6.2.2.3.1 Glass Preparation and Testing. This phase of the test work involved three glass formulas: a borosilicate reference glass provided by Savannah River known as the ARM glass, a soda-lime glass made from surrogate sludge representing tank W25 sludge, and a soda-lime glass prepared from actual W25 tank sludge. The ARM glass contains neither actual nor simulated waste. Rather, it is a reference glass used as a control for the Product Consistency Test (PCT). The ARM glass was provided as a single chunk of glass and was therefore not melted but rather size reduced prior to leaching (PCT). The leaching performance of this glass has been well documented at the Savannah River Technology Center (SRTC) and is therefore used as a control. ${ }^{68}$ The surrogate glass was based upon a sludge composition which best represented the tank sludge. This composition is presented in Table 35.

A sample of well-blended, centrifuged W25 tank sludge, with a water content of $50.5 \mathrm{wt} \%$, was used to prepare the glass. Typically, sludges from this tank have a water content between 60 to $80 \mathrm{wt} \%$, depending on the removal technique employed. This sludge and its properties have been well characterized. ${ }^{67}$

For both the surrogate sludge and the actual sludge, the sludges were weighed into new $90-\mathrm{mL}$ platinum crucibles and precipitated silica and finely powdered limestone were blended to the desired homogeneity based upon color using a spatula with manipulator grips attached. The glass formulation developed by SRTC was used to prepare two of the glasses, one with the W25 sample and one with the W25 surrogate. This glass formulation is as follows:

$\begin{array}{lc}\text { Waste } & 25.0 \mathrm{~g} \text { of dry sludge (dried at } 105^{\circ} \mathrm{C} \text { for } 24 \mathrm{~h} \text { ) } \\ \text { Precipitated silica } & 14.2 \mathrm{~g} \\ \text { Calcium carbonate } & 8.12 \mathrm{~g}\end{array}$

The density of the glass was not checked but was expected to be $2.87 \mathrm{~g} / \mathrm{mL}$ per the SRTC test work with W25 surrogate. The surrogate-based glass produced a button of glass weighing $32.73 \mathrm{~g}$, while the test with actual tank waste resulted in $38.26 \mathrm{~g}$. The glasses produced were dark brown in color and were found to be much softer, based upon crushing and screening activities, than the borosilicate-based ARM glass provided by SRTC.

The two glasses produced from the W25 sample and the W25 surrogate were found to stick to the bottom of the platinum crucibles. The $1300^{\circ} \mathrm{C}$ crucibles were removed from the furnace using special tongs adapted for use with the manipulator. Once removed, they were quickly quenched in ice water, hoping that the thermal shock would loosen the glass from the crucible. This step alone did not work, so the bottoms of the room temperature crucibles were placed just below the surface of liquid nitrogen pumped into the cell. The crucibles had a small amount of clean glass quartz wool placed in the top of the crucible so that glass could not be ejected during cooling. Again, this step alone failed to release the glass from the crucible; however, in one case, the glass shattered upon setting overnight and all the glass broke free upon tapping the bottoma type of delayed reaction. With another crucible, following the use of liquid nitrogen, quartz 
wool was placed inside the crucible and the bottom of the crucible was repeatedly dropped onto the cell working surface from a height of approximately 4 in. until it shattered.

The platinum crucibles were set into clay crucibles inside the furnace to protect the oven refractory. The furnace was started at ambient temperature in the cell $\left(27-29^{\circ} \mathrm{C}\right)$ with the crucible inside and the furnace programmed to ramp at $15^{\circ} \mathrm{C} / \mathrm{min}$ to $1300^{\circ} \mathrm{C}$ and then hold this temperature for a minimum of $4 \mathrm{~h}$. The surrogate blend used a hold time of $4 \mathrm{~h}$; however, for the glass formed from actual waste, a hold time of $4.75 \mathrm{~h}$ was used since it was more difficult to mix the ingredients in the hot cell.

After removing the glass samples from the furnace, they were handled in accordance with the PCT procedure. ${ }^{68}$ Implementing this procedure required modification of equipment necessary to pulverize, screen to the proper mesh size, wash, and separate the glass samples so that cross contamination did not occur.

A small pulverizer using tungsten carbide blades was mated to a support stand that cradled it. An attached handle with a swivel permitted the manipulator hand to tilt the whole pulverizer forward to empty its contents of ground glass onto a series of screens, with a catch pan underneath. For pieces of glass that were thought to be too large for the pulverizer, small chunks were placed inside a stainless steel cylinder and hammered with a heavy steel tube. The size-reduced glass was then poured directly into the top of the pulverizer.

A stainless steel funnel, that tightly fits inside the screening pans, was used to transfer the 100 - to 200-mesh size glass particles into a plastic bottle, which was screwed onto the funnel spout.

Properly screened and washed glass was eventually put into precleaned Parr leaching bombs for use in the PCT test. The details of the complete test are described in ASTM C $1285 .{ }^{69}$ The bombs received approximately $1.6 \mathrm{~g}$ of glass each, and the tops were torqued to $40 \mathrm{ft}-\mathrm{lb}$, the maximum recommended by the manufacturer.

\subsubsection{Soda Lime-Based Glass Test Results}

6.2.2.4.1 Product Consistency Test (PCT). Table 38 lists the elemental leachate concentrations from the PCT tests. The results for the glass made by vitrifying the W25 sludge sample and the surrogate W25 sludge were comparable, indicating that the surrogate sludge was representative of actual tank sludge.

The PCT test required that a high purity standard be carried through the test procedures and then analyzed. A standard solution was purchased from High-Purity Standards of Charleston, South Carolina, marked as lot \# 691218 and prepared in $2 \%$ nitric acid. The concentrations are certified to within $\pm 0.5 \%$ at the ppm level. Table 39 lists the standard concentrations and the recoveries on the standard, ICP recoveries, blanks and carrythrough standard. These solutions were analyzed by a TJA 61E trace ICP, with three burns each and data reported at the 95\% CI.

Table 40 lists the radioelement concentrations measured in the PCT leachates of the glass made from the W25 sludge sample. 
6.2.2.4.2 Toxicity Characteristic Leaching Procedure (TCLP) Test. The TCLP extract concentrations for the glass made by vitrifying theW25 sludge sample and the surrogate W25 sludge are listed in Table 37 . The W25 sludge sample was characteristically hazardous for mercury and also failed the UTS limit for chromium. The TCLP extract concentrations for both glass- and grout-treated W25 sludge were well below the UTS limits. The TCLP extract concentrations for the glass made from the surrogate W25 sludge were comparable with that for the glass made from the W25 sludge sample, indicating the surrogate performance was representative of the actual tank sludge. In general, treatment-grout or glass-significantly improved the TCLP concentrations, sometimes by more than an order of magnitude.

6.2.2.4.3 Volatility of Radioelements from the W25 Glass. A sample of the sludge used in the melt crucible was counted by gamma spectroscopy, along with an NBS standard, to ensure that the system was operating properly. Additionally, an 18-g sample of the W25 glass was also counted in order to establish the amounts volatilized. Results revealed that the final glass contained $11 \mu \mathrm{Ci} / \mathrm{g}{ }^{137} \mathrm{Cs}, 1.6 \mu \mathrm{Ci} / \mathrm{g}{ }^{60} \mathrm{Co}$, and $1.8 \mu \mathrm{Ci} / \mathrm{g}{ }^{154} \mathrm{Eu}$. Based upon the data obtained for the raw sludge, which contained approximately $50 \%$ water, $58 \%$ of the ${ }^{137} \mathrm{Cs}, 19 \%$ of the ${ }^{60} \mathrm{Co}$, and $10 \%$ of the ${ }^{154} \mathrm{Eu}$ were lost through volatilization from the crucible glass.

\section{SUMMARY AND CONCLUSIONS}

Robust grout and glass formulations capable of solidifying all ORNL tank sludges were developed. Waste forms produced from a sample of actual tank sludge performed similarly to these from a surrogate for that tank sludge, indicating that the results obtained for the surrogates were representative of that for tank sludges. The composition of the sludge from tank W25 was an outlier among the set of characterization data for the MVST/BVEST sludges. For this reason, a surrogate was designed specifically for the W25 sample. The W25 surrogate performed significantly different from the weighted average surrogate for this set of tanks. This illustrated that the performance for a given sample or a given tank sludge may be quite different from the performance for a surrogate based on an average composition. A robust formulation must be designed to account for this performance variation so that applicable disposal criteria are met.

The robust grout formulation was effective for the range of surrogate sludge compositions that represent the ORNL tank sludges. Grout sludge loading was limited by the chromium TCLP, bleed water, and strength performance. If the water-to-solids ratio of the grout was controlled, sludge loadings as high as $90 \mathrm{wt} \%$ could be used without bleed water. The chromium TCLP performance or strength performance criteria would limit the loading to $<70 \mathrm{wt} \%$. The limited available data imply that the chromium present in the actual ORNL tank sludges is in the trivalent rather than the hexavalent or chromate form. The TCLP performance of the actual W25 for chromium tends to confirm this hypothesis (Table 36). This means that the chromium actually present in the sludge may not require stabilization, and if there is no strength criterion, sludge loadings as high as $90 \mathrm{wt} \%$ can be used by controlling the water-to-solids ratio. Sludge loadings this high may result in volume increases of $<10 \mathrm{vol} \%$. The economic analysis indicates that higher expansion factors add significantly to the storage, transportation, and disposal costs. ORNL personnel will perform additional refinements to the grout formulation in FY 1998 and 
tailor the formulation for specific ORNL tank sludges to maximize sludge loading and minimize volume increase.

The SRTC developed a more-refined formula for a soda-lime-silica (SLS) glass, originally developed by ORNL for MVST sludge. Although the SLS glass TCLP results are not available yet, it is anticipated that the glass had no problems with chromium stabilization. On the other hand, the W25 sludge sample failed TCLP only for mercury, which is not stabilized in glass, as mercury volatilizes during vitrification and must be captured from the off-gas and handled in the secondary wastes. Lowering the glass melt temperature from $1400^{\circ} \mathrm{C}$ to $1300^{\circ} \mathrm{C}$ helped in controlling cesium volatility, but close to $60 \mathrm{wt} \%$ of the ${ }^{137} \mathrm{Cs}$ may have volatilized in the simple crucible vitrification of the W25 sludge sample. Field operations employ schemes, such as cold caps, to control ${ }^{137} \mathrm{Cs}$ volatilization. Further refinements should be possible to improve vitrification and the performance of the glass product. Further details regarding the performance of the SLS glass will be provided by SRTC in a separate report. SRTC will perform additional refinements to the glass formula in FY 1998 and tailor the formula for specific ORNL tank sludges. $^{70}$

In summary, both the grout and SLS glass effectively stabilized the contaminants that were retained in the waste form. Mercury, the RCRA metal for which the W25 sample was characteristically hazardous, volatilizes during vitrification and must be trapped and treated as a secondary waste. The grout effectively stabilized the mercury in the W25 sample. Grouting at a sludge loading of $60 \mathrm{wt} \%$ is expected to increase the volume by about $32 \mathrm{vol} \%$ over the existing sludge volume, and vitrification is expected to decrease the volume by about $56 \mathrm{vol} \%$. This leads directly to an increase in packaging and disposal costs for the increased volume of grout over glass. ORNL will perform additional refinements to the grout formulation in FY 1998 and tailor the formulation for specific ORNL tank sludges to maximize sludge loading and minimize volume increase. SRTC will perform additional refinements to the glass formula in FY 1998 and tailor the formula for specific ORNL tank sludges.

\section{ACKNOWLEDGMENTS}

The authors gratefully acknowledge the laboratory work by Mike Burgess; the remote operation in the hot cell by Jim Travis; the assistance with radiotagging and counting by Debbie Bostick; the secretarial and administrative assistance of Linda Puckett; the editorial assistance of Debbie Stevens; the electronic publishing support in preparation of the final report provided by Sandra Lyttle; and the support and guidance from John Plodinec and Bill Holtzscheiter of the TFA, Jacquie Noble-Dial and Cavanaugh Mims of DOE-ORO, and Tim Kent and Sharon Robinson of ORNL. 


\section{REFERENCES}

1. R. D. Spence and T. M. Gilliam, Grout and Glass Performance in Support of Stabilization/Solidification of the MVST Tank Sludges, ORNL/TM-13652, September 1998.

2. C. K. Bayne, S. M. DePaoli, J. R. DeVore (ed.), D. J. Downing, and J. M. Keller, Statistical Description of Liquid Low-Level Waste System Transuranic Wastes at Oak Ridge National Laboratory, Oak Ridge, Tennessee, ORNL/TM-13351, December 1996.

3. J. M. Keller, J. M. Giaquinto, and A. M. Meeks, Characterization of the MVST Waste Tanks Located at ORNL, ORNL/TM-13357, December 1996.

4. J. M. Keller, J. M. Giaquinto, and A. M. Meeks, Characterization of the BVEST Waste Tanks Located at ORNL, ORNL/TM-13358, January 1997.

5. J. M. Keller, J. M. Giaquinto, and A. M. Meeks, Characterization of the Old Hydrofracture Facility (OHF) Waste Tanks Located at ORNL, ORNL/TM-13394, April 1997.

6. J. M. Giaquinto, J. M. Keller, and T. P. Mills, Miscellaneous Data for the 1996-1997 Sampling and Analysis Campaigns of the MVST, BVEST, and OHF Tank Complexes, ORNL/TM-13455, July 1997.

7. F. G. Smith III to J. C. Marek, "Average Sludge Composition in ORNL GAAT Tanks W6-W10 (U)," SRT-GAT-96-005, Westinghouse Savannah River Company, Savannah River Technology Center, August 5, 1996.

8. J. R. Conner, Chemical Fixation and Solidification of Hazardous Wastes, Van Nostrand Reinhold, New York, 1990.

9. International Atomic Energy Agency, Improved Cement Solidification of Low and Intermediate Level Radioactive Wastes, Technical Reports Series No. 350, International Atomic Energy Agency, Vienna, 1993.

10. F. M. Lea, The Chemistry of Cement and Concrete, 3rd edition, Chemical Publishing Co., Inc., New York, 1970.

11. I. Soroka, Portland Cement Paste and Concrete, Chemical Publishing Co., Inc., New York, 1979.

12. G. C. Bye, Portland Cement Composition, Production, and Properties, Pergamon Press, New York, 1983.

13. S. N. Ghosh, editor, Advances in Cement Technology Critical Reviews and Case Studies on Manufacturing, Quality Control, Optimization and Use, Pergamon Press, New York, 1983. 
14. H. F. W. Taylor, Cement Chemistry, Academic Press, New York, 1990.

15. U.S. EPA, Fed. Regist. 52(155), 29999 (Aug. 12, 1987).

16. K. M. Armstrong and L. M. Klingler, "Evaluation of a Unique System for the Thermal Processing of Radioactive and Mixed Wastes," CONF-860223-1, 1986.

17. P. Cote, Contaminant Leaching from Cement-Based Waste Forms Under Acidic Conditions, Ph.D. Thesis, McMaster Univ., Hamilton, Ont., Canada, 1986.

18. ASTM C 150-89, "Standard Specification for Portland Cement," pp. 92-96 in 1991 Annual Book of ASTM Standards Section 4 Construction, Vol. 04.02, Concrete and Aggregates, American Association for Testing and Materials, Philadelphia, Pa., 1991.

19. W. Laguna, "Radioactive Waste Disposal by Hydraulic Fracturing," Ind. Water Eng. 32-132 (October 1970).

20. T. G. Clendenning, A. E. Dalrymple, and T. W. Klym, "Current Technology in the Utilization and Disposal of Coal Ash," Eng Con '75 (1975).

21. E. E. Berry and V. M. Malhotra, "Fly Ash for Use in Concrete-A Critical Review," J. Am. Concr. Inst. 77(8), 59-73 (1980).

22. R. O. Lane and J. F. Best, "Properties and Use of Fly Ash in Portland Cement Concrete," Concr. Int. 4(7), 81-92 (1982).

23. R. E. Davis, R. W. Carlson, J. W. Kelley, and H. E. Davis, "Properties of Cement and Concrete Containing Fly Ash," ACI J, Proc. 33(5), 577-612 (1937).

24. E. W. McDaniel, M. T. Morgan, J. G. Moore, H. E. Devaney, and L. R. Dole, Strontium Leachability of Hydrofracture Grouts for Sludge-Slurries, ORNL/TM-8198, March 1982.

25. J. G. Moore, H. W. Godbee, A. H. Kibbey, and D. S. Joy, Development of Cementitious Grouts for the Incorporation of Radioactive Wastes. Part 1: Leach Studies, ORNL-4962, August 1975.

26. J. G. Moore, Development of Cementitious Grouts for the Incorporation of Radioactive Wastes. Part 2: Continuation of Cesium and Strontium Leach Studies, ORNL-5142, September 1976.

27. A. Atkinson, K. Nelson, and T. M. Valentine, "Leach Test Characterization of CementBased Nuclear Waste Forms," pp. 242-53 in Nuclear and Chemical Waste Management, Vol. 6, 1986. 
28. ASTM C 618-91, "Standard Specification for Fly Ash and Raw or Calcined Natural Pozzolan for Use as a Mineral Admixture in Portland Cement Concrete," pp. 303-305 in 1991 Annual Book of ASTM Standards Section 4 Construction, Vol. 04.02, Concrete and Aggregates, American Association for Testing and Materials, Philadelphia, Pa., 1991.

29. T. M. Gilliam and J. A. Loflin, Leachability Studies of Hydrofracture Grouts, ORNLTM9879, Oak Ridge National Laboratory, November 1986.

30. T. M. Gilliam, "Leach Testing of Hydrofracture Grouts Containing Hazardous Waste," Journal of the Underground Injection Practices Council 1, 192-212 (1986).

31. T. L. Sams, E. W. McDaniel, R. D. Spence, and T. M. Gilliam, Formulation Studies and Grout Development for Fixation of Neutralized Cladding Removal Waste, Milestone No. 181 - Part II, ORNL-6283.

32. T. Tamura, "Cesium Sorption Reactions as Indicator of Clay Mineral Structures," Clays Clay Minerals, Proc. Natl. Conf. Clays Clay Minerals, 10, 389-98 (1961).

33. T. Tamura, "Cesium Sorption Reactions as Indicator of Clay Mineral Structures," Intern. Clay Conf., Proc. Conf. Stockholm 1, 229-237 (1963).

34. T. Tamura and D. G. Jacobs, "Structural Implications in Cesium Sorption," Health Physics 2, 391-98 (1960).

35. R. W. Nurse, "Slag Cements," pp. 37-68 in The Chemistry of Cements, Vol. 2, H. F. W. Taylor, ed., Academic Press, N.Y., 1984.

36. J. Daube and R. Bakker, "Portland Blast Furnace Slag Cement: A Review," pp. 5-14 in Blended Cements, edited by G. Frohnnsdorff, ASTM STP 897, ASTM, Philadelphia, Pa., 1986.

37. G. Frigione, "Manufacture and Characteristics of Portland Blast-Furnace Slag Cements," pp. 15-28 in Blended Cements, edited by G. Frohnnsdorff, ASTM STP 897, ASTM, Philadelphia, Pa., 1986.

38. V. S. Dubovoy, S. H. Gebler, P. Klieger, and D. A. Whiting, "Effects of Ground Granulated Blast-Furnace Slags on Some Properties of Pastes, Mortars, and Concretes," pp. 29-48 in Blended Cements, edited by G. Frohnnsdorff, ASTM STP 897, ASTM, Philadelphia, Pa., 1986.

39. R. H. Mills, "Chemical Shrinkage and Differential Sorptions in Mixtures of Portland Cement and Blast-Furnace Slag," pp. 49-61 in Blended Cements, edited by G. Frohnnsdorff, ASTM STP 897, ASTM, Philadelphia, Pa., 1986.

40. A. M. Neville, Properties of Concrete, 3rd ed., Edward Arnold, Glasgow, 1970. 
41. J. D. Palmer and D. L. G. Smith, The Incorporation of Low- and Medium-Level Radioactive Wastes (Solids and Liquids) in Cement, EUR-10561-EN, Commission of the European Communities, Luxembourg, 1986.

42. O. Brown, D. J. Lee, M. S. T. Price, and D. L. G. Smith, "Cement Based Processes for the Immobilization of Intermediate-Level Waste," Radioactive Waste Management, British Nuclear Society, London, 1985.

43. F. P. Glasser and C. McCulloch, Characterization of Radioactive Waste Forms, Progress Report for 1986, EUR-11354, Commission of the European Communities, Luxembourg, 1986.

44. M. J. Angus and F. P. Glasser, "The Chemical Environment in Cement Matrixes," Mater. Res. Soc. Symp. Proc. 50, 547-56 (1986).

45. R. D. Spence, W. D. Bostick, E. W. McDaniel, T. M. Gilliam, J. 1. Shoemaker, O. K. Tallent, I. L. Morgan, B. S. Evans-Brown, and K. E. Dodson, "Immobilization of Technetium in Blast Furnace Slag Grouts," presented at the 3rd International Conference on the Use of Fly Ash, Silica Fume, Slag \& Natural Pozzolans in Concrete, Trondheim, Norway, June 19-24, 1989.

46. T. M. Gilliam et al., "Solidification/Stabilization of Technetium in Cement-Based Grouts," J. Haz. Mater. 24 189-197 (1990).

47. R. D. Spence et al., "Cementitious Stabilization of Chromium, Arsenic, and Selenium in a Cooling Tower Sludge," presented at the 88th Annual Meeting of the Air \& Waste Management Association in San Antonio, Tex., June 18-23, 1995.

48. S. B. Clark and E. L. Wilhite, "Low-Level Liquid Waste Disposal at the Savannah River Site: A Large Scale Demonstration of Saltstone," WSRC-MS-90-210, DE92 009907 , Westinghouse Savannah River Co., Savannah River Laboratory, Aiken, S.C., presented at Waste Management '91, Tucson, Ariz., February 24-28, 1991.

49. C. A. Langton, M. D. Dukes, and R. V. Simmons, "Cement-Based Waste Forms for Disposal of Savannah River Plant Low-Level Radioactive Salt Waste," DP-MS-83-71, CONF-831174-61, DE84 005197, Savannah River Laboratory, Aiken, S.C., for the Materials Research Society Annual Meeting, Boston, Mass., Nov. 14-17, 1983.

50. C. A. Langton, "Solidification of Low-Level Radioactive Waste at the Savannah River Site," WSRC-RP-89-288, DE89 013770, Westinghouse Savannah River Company, Savannah River Laboratory, Aiken, S.C., presented at the NIST and NRC Workshop Cement Solidification of Low Level Radioactive Waste, Gaithersburg, Md., May 31 to June 12, 1989. 
51. C. A. Langton and P. B. Wong, "Properties of Slag Concrete for Low-Level Waste Containment," WSRC-MS-91-073, DE92 013194, Westinghouse Savannah River Company, Aiken, S.C., presented at the American Concrete Institute Spring Meeting, March 17-21, 1991.

52. D. W. Pepper, Transport of Nitrate from a Large Cement-Based Wasteform, DPST-85-963, DE88 004271, Savannah River Laboratory, Aiken, S.C., 1986.

53. H. C. Wolf, Large-Scale Demonstration of Disposal of Decontaminated Salt as Saltstone Part I: Construction, Loading, and Capping of Lysimeters, Savannah River Laboratory, Aiken, S.C., 1984.

54. S. B. Clark and E. L. Wilhite, "Low-Level Liquid Waste Disposal at the Savannah River Site: A Large Scale Demonstration of Saltstone," WSRC-MS-90-210, DE92 009907, Westinghouse Savannah River Co., Savannah River Laboratory, Aiken, S.C., presented at Waste Management '91, Tucson, Ariz., Feb. 24-28, 1991.

55. ASTM C 989-89, "Standard Specification for Ground Granulated Blast-Furnace Slag for Use in Concrete and Mortars," pp. 492-96 in 1991 Annual Book of ASTM Standards Section 4 Construction, Vol. 04.02, Concrete and Aggregates, American Association for Testing and Materials, Philadelphia, Pa., 1991.

56. ASTM C 204-91a, "Standard Specification for Fineness of Portland Cement by Air Permeability Apparatus," pp. 155-61 in 1991 Annual Book of ASTM Standards Section 4 Construction, Vol. 04.01, Cement; Lime; Gypsum, American Association for Testing and Materials, Philadelphia, Pa., 1991.

57. T. L. Sams, O. K. Tallent, and E. W. McDaniel, Preliminary Results of Grout Formulation Studies with Double Shell Slurry, Milestone 59, ORNL/TM-9824.

58. T. M. Gilliam, E. W. McDaniel, L. R. Dole, H. A. Friedman, J. A. Loflin, A. J. Mattus, I. L. Morgan, O. K. Tallent, and G. A. West, Summary Report on the Development of a CementBased Formula to Immobilize Hanford Facility Waste, ORNL/TM-10141 (September 1987).

59. E. W. McDaniel, T. M. Gilliam, and L. R. Dole, "Recommended Major Grout Components, ORNL Milestone \# 32, Project B-475, Transportable Grout Facility," letter report for the Hanford Grout Program (Apr. 15, 1984).

60. D. K. Smith, Cementing, Monograph Volume 4, SPE Henry L. Doherty Series, Society of Petroleum Engineers, Inc., New York, 1990.

61. D. K. Smith, "Physical Properties of Gel Cements," Pet. Eng., B7-B12 (April 1951).

62. R. E. Grim, Applied Clay Mineralogy, McGraw-Hill, New York, 1962. 
63. Technical Bulletin Data No. 201, American Callard Co., Chicago, Ill., 1945.

64. W. de Laguna et al., Engineering Development of Hydraulic Fracturing as a Method for Permanent Disposal of Radioactive Wastes, ORNL-4259, August 1968.

65. API Specification for Oil-Well Drilling-Fluid Materials, API Spec 12A, 9th edition, American Petroleum Institute, Dallas, Tex., March 1983.

66. "Specifications for Materials and Testing Oil-Well Cements," in API Specification 10, 2nd edition, API, Dallas, 1984.

67. J. L. Collins, B. Z. Egan, E. C. Beahm, C. W. Chase, and K. K. Anderson, Characterization and Leaching Study of Sludge from Melton Valley Storage Tank W25, ORNL/TM-13445, October 1997.

68. C. M. Jantzen, N. E. Bibler, D. C. Beam, W. G. Ramsey, and B. J. Waters, Nuclear Waste Glass Product Consistency Test (PCT)-Version 5.0(U), Westinghouse Savannah River Co., WSRC-TR-90-539, Rev. 2, January 1992 (see also ASTM vol. 1502).

69. ASTM C 1285-94, Standard Test Methods for Determining Chemical Durability of Nuclear Waste Glasses: The Product Consistency Test (PCT), American Society for Testing and Materials, Philadelphia, Pa., 1994.

70. M. K. Andrews, J. R. Harbour, T. B. Edwards, and P. J. Workman, Glass Waste Forms for Oak Ridge Tank Wastes: Fiscal Year 1997 Report for Task Plan SR-16WT-31, Task A, WSRC-TR-97-00391, October, 1997. 
.

. 
APPENDIX

HOT CELL D AND EQUIPMENT 


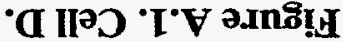

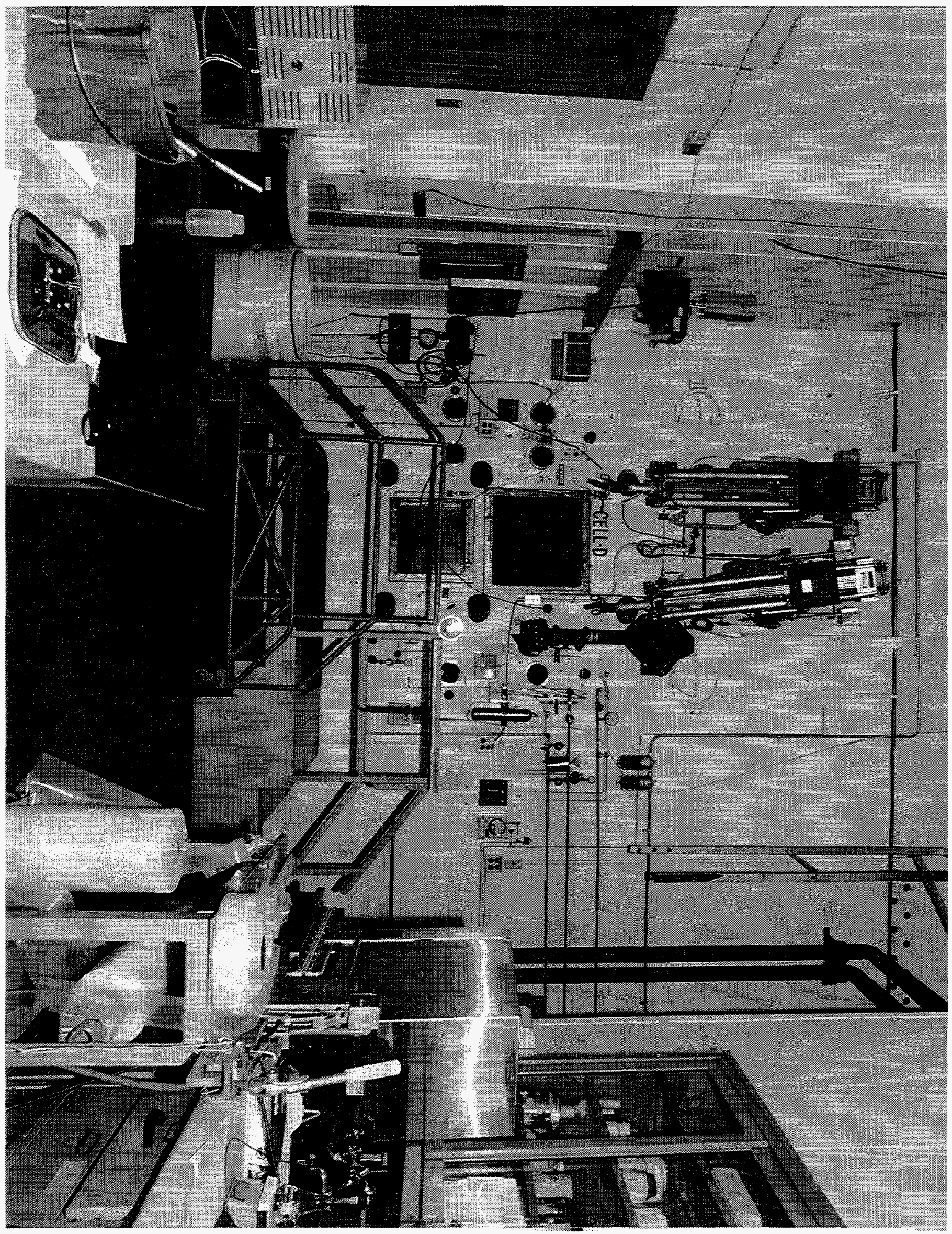




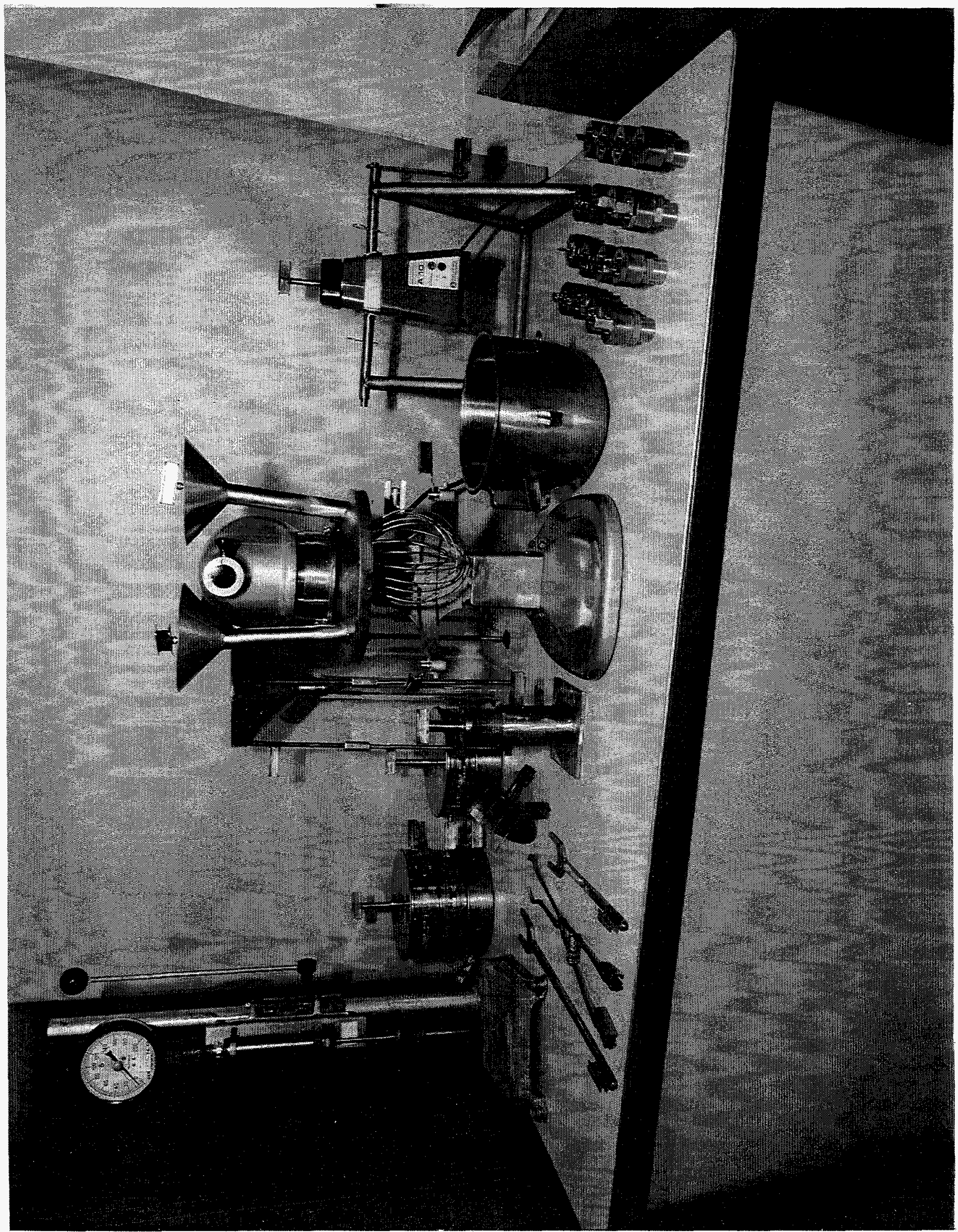

Figure A.2. Equipment installed in Cell D. 
Table 1. Summary of ORNL tank sludge surrogate compositions

\begin{tabular}{|c|c|c|c|c|c|}
\hline \multirow[b]{2}{*}{ Compound } & \multicolumn{5}{|c|}{ Surrogate compositions $(\mathrm{mg} / \mathrm{kg}$ ) } \\
\hline & $\begin{array}{c}\text { Overall weighted } \\
\text { average }\end{array}$ & MVST-BVEST $^{a}$ & GAAT & $\begin{array}{c}\text { Old } \\
\text { hydrofracture }\end{array}$ & W25 sample ${ }^{b}$ \\
\hline \multicolumn{6}{|c|}{ RCRA metals } \\
\hline $\mathrm{Ag}_{2} \mathrm{O}$ & 7 & 19 & 0 & 0 & 0 \\
\hline $\mathrm{Ba}(\mathrm{OH})_{2} \cdot 8 \mathrm{H}_{2} \mathrm{O}$ & 0 & 0 & 0 & 0 & 463 \\
\hline $\mathrm{CdO}$ & 17 & 23 & 0 & 11 & 29 \\
\hline $\mathrm{Na}_{2} \mathrm{Cr}_{2} \mathrm{O}_{7} \cdot 2 \mathrm{H}_{2} \mathrm{O}$ & 680 & 255 & 1,284 & 281 & 866 \\
\hline $\mathrm{HgCl}_{2}$ & 84 & 40 & 124 & 151 & 136 \\
\hline $\mathrm{PbO}$ & 588 & 296 & 1,423 & 420 & 1,085 \\
\hline $\mathrm{NiO}$ & 0 & 0 & 0 & 0 & 256 \\
\hline $\mathrm{SeO}_{2}$ & 26 & 66 & 0 & 0 & 0 \\
\hline $\mathrm{TINO}_{3}$ & 15 & 21 & 0 & 0 & 0 \\
\hline $\mathrm{ZnO}$ & 460 & 0 & 0 & 196 & 502 \\
\hline \multicolumn{6}{|c|}{ Process metals, salts, and organics } \\
\hline $\mathrm{Al}(\mathrm{OH})_{3}$ & 21,181 & 9,883 & 43,431 & 39,201 & 37,570 \\
\hline $\mathrm{CaCO}_{3}$ & 81,280 & 66,517 & 0 & 69,061 & 96,615 \\
\hline $\mathrm{Ca}(\mathrm{OH})_{2}$ & 4,282 & 22,104 & 21,211 & 0 & 17,870 \\
\hline $\mathrm{Fe}_{2} \mathrm{O}_{3}$ & 5,432 & 2,000 & 10,975 & 7,035 & 6,193 \\
\hline $\mathrm{KNO}_{3}$ & 22,957 & 37,821 & 0 & 0 & 18,755 \\
\hline $\mathrm{K}_{2} \mathrm{CO}_{3}$ & 0 & 0 & 7,829 & 5,483 & 0 \\
\hline $\mathrm{MgCO}_{3}$ & 0 & 3,286 & 0 & 9,054 & 0 \\
\hline $\mathrm{MgO}$ & 10,997 & 12,577 & 4,790 & 0 & 11,272 \\
\hline $\mathrm{NaOH}$ & 8,508 & 0 & 20,750 & 0 & 65,375 \\
\hline $\mathrm{Na}_{2} \mathrm{CO}_{3}$ & 0 & 0 & 24,026 & 3,794 & 0 \\
\hline $\mathrm{NaNO}_{3}$ & 113,493 & 278,665 & 0 & 0 & 50,064 \\
\hline $\mathrm{NaNO}_{2}$ & 4,599 & 0 & 0 & 3,063 & 0 \\
\hline $\mathrm{NaBr}$ & 251 & 0 & 0 & 31 & 454 \\
\hline $\mathrm{NaCl}$ & 2,919 & 4,329 & 1,716 & 761 & 3,014 \\
\hline $\mathrm{NaF}$ & 1,322 & 1,427 & 4,470 & 463 & 2,115 \\
\hline $\mathrm{Na}_{2} \mathrm{SO}_{4}$ & 4,044 & 2,707 & 7,994 & 2,096 & 5,214 \\
\hline $\mathrm{Na}_{3} \mathrm{PO}_{4} \cdot 12 \mathrm{H}_{2} \mathrm{O}$ & 35,017 & 0 & 0 & 56,983 & 0 \\
\hline $\mathrm{SiO}_{2}$ & 10,638 & 0 & 7,888 & 27,883 & 16,487 \\
\hline $\mathrm{Sr}\left(\mathrm{NO}_{3}\right)_{2}$ & 412 & 369 & 0 & 1,160 & 6,813 \\
\hline $\mathrm{Th}\left(\mathrm{NO}_{3}\right)_{4} \cdot 4 \mathrm{H}_{2} \mathrm{O}$ & 25,146 & 14,114 & 17,546 & 0 & 68,796 \\
\hline $\mathrm{ThO}_{2}$ & 0 & 0 & 0 & 92,275 & 0 \\
\hline $\mathrm{UO}_{2}\left(\mathrm{NO}_{3}\right)_{2} \cdot 6 \mathrm{H}_{2} \mathrm{O}$ & 47,243 & 24,422 & 89,585 & 20,258 & 29,326 \\
\hline Calcium oxalate & 1,451 & 0 & 0 & 129 & 0 \\
\hline Tributylphosphate & 9,733 & 0 & 8,372 & 17,503 & 41,669 \\
\hline Subtotal & 412,783 & 480,940 & 273,413 & 357,290 & 480,940 \\
\hline \multicolumn{6}{|c|}{ Mass fraction } \\
\hline Compounds & 0.413 & 0.481 & 0.273 & 0.357 & 0.481 \\
\hline Added water & 0.587 & 0.519 & 0.727 & 0.643 & 0.519 \\
\hline
\end{tabular}

${ }^{a}$ Surrogate used in FY 1996.

${ }^{b}$ Surrogate of the actual sludge sample from Tank W25. This tank sludge sample was used in the hot test of the grout and glass formulations. 
Table 2. Overall weighted average surrogate sludge: compositions for the screening tests

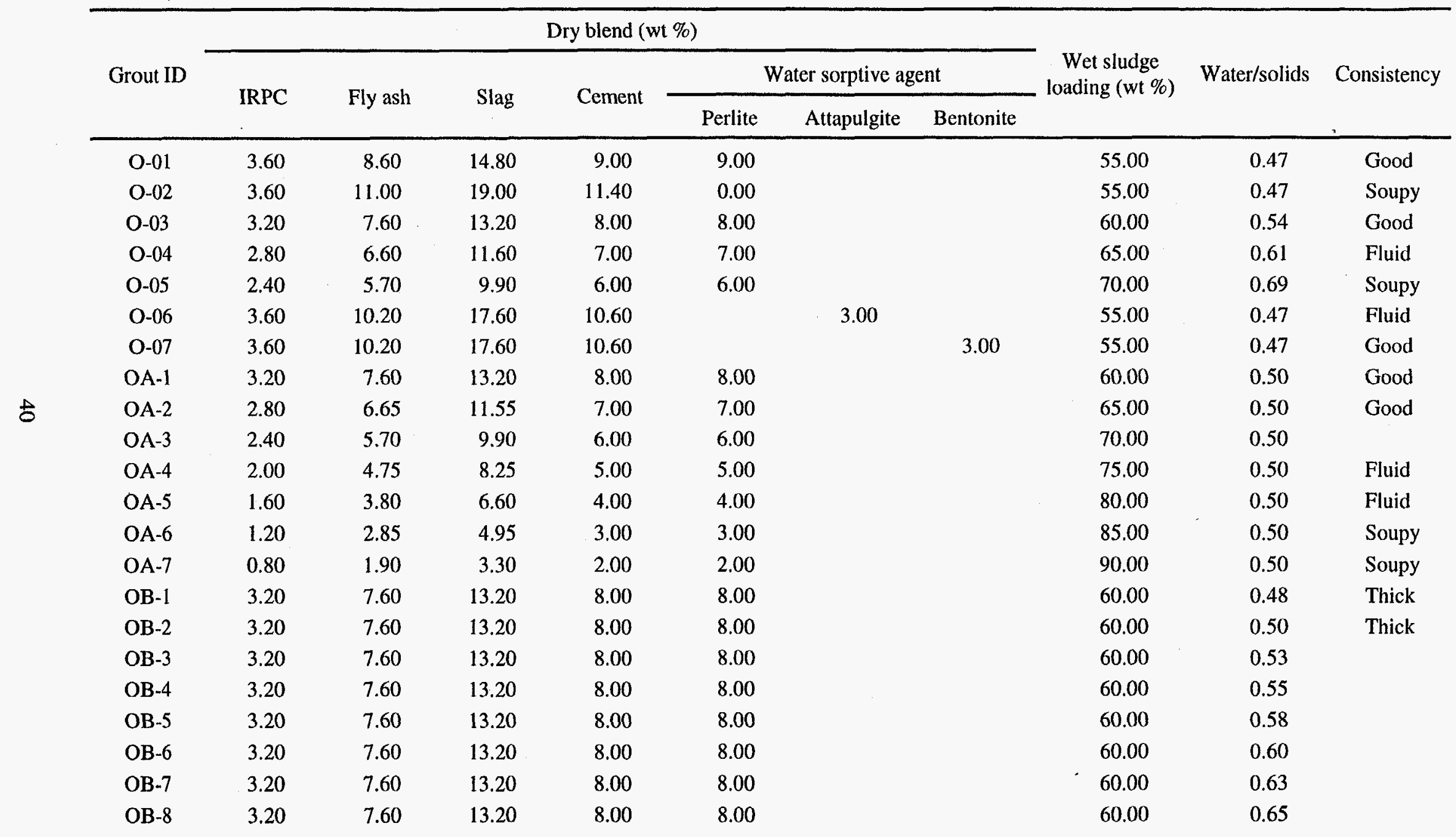


Table 2 (continued)

\begin{tabular}{|c|c|c|c|c|c|c|c|c|c|c|}
\hline \multirow{3}{*}{ Grout ID } & \multicolumn{7}{|c|}{ Dry blend (wt \%) } & \multirow{3}{*}{$\begin{array}{c}\text { Wet sludge } \\
\text { loading (wt \%) }\end{array}$} & \multirow{3}{*}{ Water/solids } & \multirow{3}{*}{ Consistency } \\
\hline & \multirow{2}{*}{ IRPC } & \multirow{2}{*}{ Fly ash } & \multirow{2}{*}{ Slag } & \multirow{2}{*}{ Cement } & \multicolumn{3}{|c|}{ Water sorptive agent } & & & \\
\hline & & & & & Perlite & Attapulgite & Bentonite & & & \\
\hline OC-1 & 3.60 & 8.55 & 14.85 & 9.00 & 9.00 & & & 55.00 & 0.48 & Thick \\
\hline $\mathrm{OC}-2$ & 3.20 & 7.60 & 13.20 & 8.00 & 8.00 & & & 60.00 & 0.55 & Good \\
\hline $\mathrm{OC}-3$ & 2.80 & 6.65 & 11.55 & 7.00 & 7.00 & & & 65.00 & 0.62 & Good \\
\hline OC-4 & 4.05 & 9.62 & 16.71 & 10.13 & 4.50 & & & 55.00 & 0.48 & Fluid \\
\hline OC-5 & 3.60 & 8.55 & 14.85 & 9.00 & 4.00 & & & 60.00 & 0.55 & Soupy \\
\hline OC-6 & 3.15 & 7.48 & 12.99 & 7.88 & 3.50 & & & 65.00 & 0.62 & Soupy \\
\hline OD-1 & 3.60 & 10.20 & 17.60 & 10.60 & & 3.00 & & 55.00 & 0.48 & \\
\hline OD-2 & 3.60 & 10.20 & 17.60 & 10.60 & & 3.00 & & 55.00 & 0.48 & \\
\hline OD-3 & 3.20 & 9.07 & 15.64 & 9.42 & & 2.67 & & 60.00 & 0.55 & Pudding \\
\hline OD-4 & 3.20 & 9.07 & 15.64 & 9.42 & & 2.67 & & 60.00 & 0.55 & Soupy \\
\hline $\mathrm{OF}-1$ & 2.80 & 6.65 & 11.55 & 7.00 & 7.00 & & & 65.00 & 0.38 & \\
\hline OF-2 & 2.80 & 6.65 & 11.55 & 7.00 & 7.00 & & & 65.00 & 0.33 & Good \\
\hline OF-3 & 2.80 & 6.65 & 11.55 & 7.00 & 7.00 & & & 65.00 & 0.29 & Thick \\
\hline OF-4 & 2.40 & 5.70 & 9.90 & 6.00 & 6.00 & & & 70.00 & 0.41 & Fluid \\
\hline OF-5 & 2.40 & 5.70 & 9.90 & 6.00 & 6.00 & & & 70.00 & 0.38 & Good \\
\hline OF-6 & 2.40 & 5.70 & 9.90 & 6.00 & 6.00 & & & 70.00 & 0.33 & Good \\
\hline OF-7 & 2.40 & 5.70 & 9.90 & 6.00 & 6.00 & & & 70.00 & 0.29 & Thick \\
\hline OF-8 & 2.00 & 4.75 & 8.25 & 5.00 & 5.00 & & & 75.00 & 0.41 & Good \\
\hline OF-9 & 2.00 & 4.75 & 8.25 & 5.00 & 5.00 & & & 75.00 & 0.38 & Fluid \\
\hline $\mathrm{OF}-10$ & 2.00 & 4.75 & 8.25 & 5.00 & 5.00 & & & 75.00 & 0.33 & Fluid \\
\hline OF-11 & 2.00 & 4.75 & 8.25 & 5.00 & 5.00 & & & 75.00 & 0.29 & Good \\
\hline $60 \mathrm{WL}$ & 3.20 & 7.60 & 13.20 & 8.00 & 8.00 & & & 60.00 & 0.35 & Good \\
\hline
\end{tabular}


Table 3. Overall weighted average surrogate sludge: free water and penetration resistance results for the screening tests

\begin{tabular}{|c|c|c|c|c|}
\hline \multirow{2}{*}{ Grout ID } & \multicolumn{2}{|c|}{ Free water $(\mathrm{vol} \%)$} & \multicolumn{2}{|c|}{ Penetration resistance (psi) } \\
\hline & $2 d$ & $7 d$ & $2 d$ & $7 \mathrm{~d}$ \\
\hline 0.01 & 0.20 & 0.00 & 2,800 & $>8,000$ \\
\hline $\mathrm{O}-02$ & 1.33 & 0.00 & 2,000 & $>8,000$ \\
\hline O-03 & 0.61 & 0.00 & 2,000 & $>8,000$ \\
\hline O-04 & 1.23 & 0.41 & 800 & 5,200 \\
\hline O-05 & 2.45 & 1.63 & 360 & 2,800 \\
\hline O-06 & 2.16 & 0.82 & 1,200 & $>8,000$ \\
\hline $0-07$ & 0.61 & 0.00 & 1,600 & $>8,000$ \\
\hline OA-1 & 0.00 & 0.00 & 80 & $>8,000$ \\
\hline $\mathrm{OA}-2$ & 0.81 & 0.00 & 0 & 3,360 \\
\hline OA-3 & 0.00 & 0.00 & 0 & 2,080 \\
\hline $\mathrm{OA}-4$ & 0.20 & 0.00 & 0 & 720 \\
\hline OA-5 & 0.60 & 0.20 & 0 & 0 \\
\hline OA-6 & 1.20 & 0.80 & 0 & 0 \\
\hline OA-7 & 0.81 & 0.81 & 0 & 0 \\
\hline OB-1 & 0.66 & 0.00 & 200 & $>8,000$ \\
\hline OB-2 & 0.00 & 0.00 & 400 & $>8,000$ \\
\hline OB-3 & 0.40 & 0.00 & 1,000 & $>8,000$ \\
\hline $\mathrm{OB}-4$ & 0.40 & 0.00 & 1,200 & $>8,000$ \\
\hline OB-5 & 0.40 & 0.00 & 2,000 & $>8,000$ \\
\hline OB-6 & 0.50 & 0.00 & 1,600 & $>8,000$ \\
\hline OB-7 & 1.50 & 0.00 & 1,600 & $>8,000$ \\
\hline OB-8 & 1.20 & 0.00 & 1,600 & $>8,000$ \\
\hline OC-1 & 1.30 & 0.40 & 2,480 & $>8,000$ \\
\hline OC-2 & 0.30 & 0.00 & 2,000 & $>8,000$ \\
\hline OC-3 & 0.00 & 0.00 & 1,600 & 6,000 \\
\hline OC-4 & 0.00 & 0.00 & 2,320 & $>8,000$ \\
\hline OC-5 & 0.00 & 0.00 & 2,160 & $>8,000$ \\
\hline OC-6 & 0.00 & 0.00 & 1,200 & 6,400 \\
\hline OD-1 & 0.00 & 0.00 & 160 & $>8,000$ \\
\hline OD-2 & 0.00 & 0.00 & 320 & $>8,000$ \\
\hline OD-3 & 0.82 & 0.00 & 0 & $>8,000$ \\
\hline OD-4 & 1.20 & 0.00 & 0 & $>8,000$ \\
\hline OF-1 & 0.40 & 0.00 & 520 & 6,840 \\
\hline OF-2 & 0.20 & 0.00 & 600 & 6,080 \\
\hline OF-3 & 0.00 & 0.00 & 1,600 & 7,120 \\
\hline OF-4 & 1.60 & 0.40 & 80 & 3,400 \\
\hline OF-5 & 1.21 & 0.00 & 80 & 3,680 \\
\hline OF-6 & 0.00 & 0.00 & 1,280 & 3,040 \\
\hline OF-7 & 0.00 & 0.00 & 1,720 & 3,600 \\
\hline OF-8 & 0.40 & 0.00 & 760 & 2,000 \\
\hline OF-9 & 1.60 & 1.20 & 440 & 1,600 \\
\hline OF-10 & 1.01 & 0.20 & 560 & 1,840 \\
\hline OF-11 & 0.00 & 0.00 & 760 & 2,360 \\
\hline $60 \mathrm{WL}$ & 0.00 & 0.00 & 0 & $>8,000$ \\
\hline
\end{tabular}


Table 4. Overall weighted average surrogate sludge: TCLP results for the screening tests

\begin{tabular}{|c|c|c|c|c|c|c|c|c|c|c|c|c|c|c|c|c|}
\hline & \multirow{2}{*}{ Sample } & \multicolumn{12}{|c|}{ Analyte $(\mathrm{mg} / \mathrm{L})$} & \multirow{2}{*}{$\mathrm{pH} 1^{\prime \prime}$} & \multirow{2}{*}{$\mathrm{pH} 2^{a}$} & \multirow{2}{*}{$\begin{array}{c}\text { Fluid } \\
\text { no. }\end{array}$} \\
\hline & & $\mathrm{Ag}$ & $\mathrm{Be}$ & $\mathrm{Cd}$ & $\mathrm{Cr}$ & $\mathrm{Ni}$ & $\mathrm{Pb}$ & $\mathrm{Se}$ & $\mathrm{Th}$ & $\mathrm{Tl}$ & $\mathrm{U}$ & $\mathrm{Zn}$ & $\mathrm{Hg}$ & & & \\
\hline & Raw & 0.022 & 0.004 & 0.011 & 19.100 & 0.050 & 0.031 & 0.172 & 2.220 & 0.053 & 830.000 & 0.325 & 1.64500 & 9.3 & 8.8 & 2 \\
\hline & RawDE & 0.022 & 0.004 & 0.015 & 20.800 & 0.055 & 0.031 & 0.196 & 2.220 & 0.053 & 887.000 & 0.294 & 1.61300 & 9.3 & 8.9 & 2 \\
\hline & Raw & 0.018 & 0.002 & 0.268 & 15.929 & 0.088 & 0.016 & 0.033 & 1.110 & 0.027 & 1,253 & 3.705 & 4.34700 & 10.0 & 6.9 & 2 \\
\hline & 01 & 0.011 & 0.002 & 0.003 & 0.024 & 0.016 & 0.016 & 0.034 & 1.110 & 0.027 & 0.222 & 0.240 & 0.00013 & 11.0 & 10.0 & 1 \\
\hline & $\mathrm{O} 2$ & 0.011 & 0.002 & 0.003 & 0.054 & 0.016 & 0.016 & 0.050 & 1.110 & 0.027 & 0.222 & 0.248 & 0.00045 & 12.1 & 10.9 & 2 \\
\hline & $\mathrm{O}(\mathrm{F} 1)$ & 0.011 & 0.002 & 0.003 & 0.073 & 0.016 & 0.016 & 0.033 & 1.110 & 0.027 & 0.222 & 0.250 & 0.00012 & 11.2 & 10.4 & 1 \\
\hline & $\mathrm{O} 3(\mathrm{~F} 2)$ & 0.011 & 0.002 & 0.003 & 0.013 & 0.043 & 0.016 & 0.048 & 1.110 & 0.027 & 230.748 & 0.051 & 0.00005 & 11.6 & 8.3 & 2 \\
\hline & $\mathrm{O} 4$ & 0.011 & 0.002 & 0.003 & 0.227 & 0.016 & 0.016 & 0.075 & 1.110 & 0.027 & 0.794 & 0.295 & 0.00020 & 11.3 & 9.9 & 2 \\
\hline & O4DE & 0.011 & 0.002 & 0.003 & 0.222 & 0.016 & 0.016 & 0.079 & 1.110 & 0.027 & 0.587 & 0.280 & 0.00008 & 11.3 & 9.9 & 2 \\
\hline & O5 & 0.011 & 0.002 & 0.003 & 1.136 & 0.016 & 0.016 & 0.061 & 1.110 & 0.027 & 0.222 & 0.274 & 0.00013 & 11.5 & 10.0 & 2 \\
\hline & O6(F1) & 0.011 & 0.002 & 0.003 & 0.108 & 0.016 & 0.016 & 0.033 & 1.110 & 0.027 & 0.288 & 0.283 & 0.00005 & 11.6 & 11.2 & 1 \\
\hline & $06(\mathrm{~F} 2)$ & 0.011 & 0.002 & 0.003 & 0.039 & 0.016 & 0.016 & 0.038 & 1.110 & 0.027 & 2.028 & 0.038 & 0.00005 & 11.9 & 9.3 & 2 \\
\hline \multirow{18}{*}{$\mathbb{\omega}$} & O7(F1) & 0.011 & 0.002 & 0.003 & 0.038 & 0.016 & 0.016 & 0.036 & 1.110 & 0.027 & 0.342 & 0.230 & 0.00023 & 11.6 & 11.4 & 1 \\
\hline & $\mathrm{O} 7(\mathrm{~F} 2)$ & 0.011 & 0.002 & 0.003 & 0.033 & 0.018 & 0.016 & 0.038 & 1.110 & 0.027 & 8.222 & 0.048 & 0.00005 & 11.9 & 9.2 & 2 \\
\hline & OA-1 & 0.011 & 0.002 & 0.003 & 0.013 & 0.016 & 0.016 & 0.069 & 1.110 & 0.027 & 192.560 & 0.245 & 0.00005 & 11.6 & 8.6 & 2 \\
\hline & $\mathrm{OA}-2$ & 0.011 & 0.002 & 0.003 & 0.067 & 0.016 & 0.016 & 0.104 & 1.110 & 0.027 & 164.229 & 0.348 & 0.00005 & 11.8 & 9.0 & 2 \\
\hline & $\mathrm{OA}-3$ & 0.011 & 0.002 & 0.003 & 0.095 & 0.016 & 0.016 & 0.114 & 1.110 & 0.027 & 287.801 & 0.291 & 0.00005 & 11.6 & 8.8 & 2 \\
\hline & OA-4 & 0.011 & 0.002 & 0.003 & 1.315 & 0.021 & 0.016 & 0.112 & 1.110 & 0.027 & 442.191 & 0.374 & 0.00005 & 11.5 & 8.7 & 2 \\
\hline & OA4DE & 0.011 & 0.002 & 0.003 & 1.678 & 0.018 & 0.016 & 0.116 & 1.110 & 0.027 & 421.334 & 0.345 & 0.00005 & 11.5 & 8.7 & 2 \\
\hline & OA-5 & 0.011 & 0.002 & 0.003 & 2.531 & 0.038 & 0.016 & 0.106 & 1.110 & 0.027 & 771.317 & 0.369 & 0.00005 & 11.4 & 8.4 & 2 \\
\hline & OA-6 & 0.011 & 0.002 & 0.004 & 4.448 & 0.050 & 0.016 & 0.060 & 1.110 & 0.027 & 825.729 & 6.614 & 0.00005 & 11.1 & 6.7 & 2 \\
\hline & OA-7 & 0.018 & 0.002 & 0.005 & 4.880 & 0.052 & 0.016 & 0.040 & 1.110 & 0.081 & 887.556 & 6.316 & 0.00005 & 10.3 & 6.3 & 2 \\
\hline & OB-1 & 0.011 & 0.002 & 0.003 & 0.013 & 0.016 & 0.016 & 0.067 & 1.110 & 0.027 & 197.636 & 0.364 & 0.00005 & 12.1 & 8.7 & 2 \\
\hline & OB-2 & 0.011 & 0.002 & 0.003 & 0.013 & 0.016 & 0.016 & 0.060 & 1.110 & 0.027 & 182.353 & 0.640 & 0.00005 & 11.9 & 8.8 & 2 \\
\hline & OB3(F1) & 0.011 & 0.002 & 0.003 & 0.078 & 0.016 & 0.016 & 0.033 & 1.110 & 0.027 & 0.222 & 0.625 & 0.00005 & 11.6 & 10.8 & 1 \\
\hline & $\mathrm{OB} 3(\mathrm{~F} 2)$ & 0.011 & 0.002 & 0.003 & 0.013 & 0.023 & 0.016 & 0.046 & 1.110 & 0.027 & 214.556 & 0.054 & 0.00006 & 11.7 & 8.5 & 2 \\
\hline & $\mathrm{OB}-4$ & 0.011 & 0.002 & 0.003 & 0.013 & 0.016 & 0.016 & 0.052 & 1.110 & 0.027 & 195.863 & 0.428 & 0.00005 & 11.7 & 8.6 & 2 \\
\hline & OB-5 & 0.011 & 0.002 & 0.003 & 0.013 & 0.016 & 0.016 & 0.060 & 1.110 & 0.027 & 197.834 & 0.458 & 0.00005 & 11.7 & 8.5 & 2 \\
\hline & OB-6 & 0.011 & 0.002 & 0.003 & 0.013 & 0.016 & 0.016 & 0.052 & 1.110 & 0.027 & 162.314 & 0.375 & 0.00005 & 11.8 & 8.7 & 2 \\
\hline & OB-7 & 0.011 & 0.002 & 0.003 & 0.013 & 0.016 & 0.016 & 0.048 & 1.110 & 0.027 & 173.536 & 0.470 & 0.00005 & 11.8 & 8.6 & 2 \\
\hline
\end{tabular}


Table 4 (continued)

\begin{tabular}{|c|c|c|c|c|c|c|c|c|c|c|c|c|c|c|c|}
\hline \multirow{2}{*}{ Sample } & \multicolumn{12}{|c|}{ Analyte $(\mathrm{mg} / \mathrm{L})$} & \multirow{2}{*}{$\mathrm{pH} 1^{a}$} & \multirow{2}{*}{$\mathrm{pH} 2^{a}$} & \multirow{2}{*}{$\begin{array}{c}\text { Fluid } \\
\text { no. }\end{array}$} \\
\hline & $\mathrm{Ag}$ & $\mathrm{Be}$ & $\mathrm{Cd}$ & $\mathrm{Cr}$ & $\mathrm{Ni}$ & $\mathrm{Pb}$ & $\mathrm{Se}$ & Th & $\mathrm{Tl}$ & U & $\mathrm{Zn}$ & $\mathrm{Hg}$ & & & \\
\hline OB8(F1) & 0.011 & 0.002 & 0.003 & 0.131 & 0.016 & 0.016 & 0.033 & 1.110 & 0.027 & 0.222 & 0.501 & 0.00007 & 11.9 & 11.1 & 1 \\
\hline $\mathrm{OB} 8(\mathrm{~F} 2)$ & 0.011 & 0.002 & 0.003 & 0.013 & 0.016 & 0.016 & 0.049 & 1.110 & 0.027 & 81.631 & 0.031 & 0.00005 & 11.8 & 8.8 & 2 \\
\hline OC-1 & 0.011 & 0.002 & 0.003 & 0.013 & 0.018 & 0.016 & 0.044 & 1.110 & 0.027 & 166.795 & 0.353 & 0.00005 & 11.8 & 8.7 & 2 \\
\hline OC-2 & 0.011 & 0.002 & 0.003 & 0.013 & 0.018 & 0.016 & 0.059 & 1.110 & 0.027 & 181.427 & 0.342 & 0.00005 & 11.8 & 8.8 & 2 \\
\hline OC-3 & 0.011 & 0.002 & 0.003 & 0.013 & 0.024 & 0.016 & 0.063 & 1.110 & 0.027 & 221.419 & 0.394 & 0.00005 & 11.8 & 8.7 & 2 \\
\hline OC3DE & 0.011 & 0.002 & 0.003 & 0.013 & 0.021 & 0.016 & 0.061 & 1.110 & 0.027 & 236.785 & 0.411 & 0.00005 & 11.8 & 8.6 & 2 \\
\hline OC-5 & 0.011 & 0.002 & 0.003 & 0.014 & 0.016 & 0.016 & 0.082 & 1.110 & 0.027 & 75.158 & 0.385 & 0.00005 & 12.0 & 9.0 & 2 \\
\hline OC-6 & 0.011 & 0.002 & 0.003 & 0.028 & 0.016 & 0.016 & 0.059 & 1.110 & 0.027 & 122.352 & 0.425 & 0.00005 & 12.1 & 9.1 & 2 \\
\hline OD-1 & 0.024 & 0.002 & 0.004 & 0.121 & 0.016 & 0.016 & 0.096 & 3.751 & 0.027 & 0.684 & 0.044 & 0.00008 & 12.1 & 10.1 & 2 \\
\hline OD-2 & 0.011 & 0.002 & 0.003 & 0.043 & 0.016 & 0.016 & 0.049 & 1.110 & 0.027 & 0.259 & 0.043 & 0.00006 & 12.2 & 10.0 & 2 \\
\hline OD-3 & 0.011 & 0.002 & 0.003 & 0.179 & 0.016 & 0.016 & 0.054 & 1.110 & 0.027 & 1.864 & 0.041 & 0.00008 & 12.2 & 9.6 & 2 \\
\hline OD 4 & 0.011 & 0.002 & 0.003 & 0.115 & 0.016 & $0: 016$ & 0.058 & 1.110 & 0.027 & 0.459 & 0.054 & 0.00008 & 12.2 & 9.9 & 2 \\
\hline OD4DE & 0.011 & 0.002 & 0.003 & 0.090 & 0.016 & 0.016 & 0.056 & 1.110 & 0.027 & 0.592 & 0.045 & 0.00009 & 12.2 & 9.9 & 2 \\
\hline OF-1 & 0.011 & 0.001 & 0.003 & 0.007 & 0.013 & 0.016 & 0.067 & 1.110 & 0.027 & 159.780 & 0.046 & 0.00009 & 11.3 & 8.9 & 2 \\
\hline OF-3 & 0.011 & 0.001 & 0.003 & 0.007 & 0.027 & 0.016 & 0.083 & 1.110 & 0.027 & 355.650 & 0.051 & 0.00090 & 11.0 & 8.7 & 2 \\
\hline $\mathrm{OF}-4$ & 0.011 & 0.001 & 0.003 & 0.007 & 0.024 & 0.016 & 0.074 & 1.110 & 0.027 & 300.436 & 0.051 & 0.00006 & 11.1 & 8.7 & 2 \\
\hline $\mathrm{OF}-5$ & 0.011 & 0.001 & 0.003 & 0.007 & 0.029 & 0.016 & 0.100 & 1.110 & 0.027 & 354.856 & 0.058 & 0.00034 & 11.2 & 8.7 & 2 \\
\hline OF5DE & 0.011 & 0.001 & 0.003 & 0.007 & 0.025 & $\$ .016$ & 0.106 & 1.110 & 0.027 & 325.727 & 0.044 & 0.00059 & 11.2 & 8.8 & 2 \\
\hline OF-6 & 0.011 & 0.001 & 0.003 & 0.007 & 0.026 & 0.016 & 0.106 & 1.110 & 0.027 & 345.148 & 0.044 & 0.00112 & 11.0 & 8.7 & 2 \\
\hline OF.7 & 0.011 & 0.001 & 0.003 & 0.007 & 0.026 & 0.016 & 0.103 & 1.110 & 0.027 & 335.301 & 0.052 & 0.00009 & 11.1 & 8.7 & 2 \\
\hline OF-8 & 0.011 & 0.001 & 0.003 & 0.556 & 0.034 & 0.016 & 0.116 & 1.110 & 0.027 & 447.596 & 0.142 & 0.00006 & 10.6 & 8.4 & 2 \\
\hline OF-9 & 0.011 & 0.001 & 0.003 & 1.604 & 0.034 & 0.016 & 0.108 & 1.110 & 0.027 & 457.672 & 0.049 & 0.00019 & 11.1 & 8.6 & 2 \\
\hline OF -10 & 0.011 & 0.001 & 0.003 & 1.009 & 0.043 & 0.016 & 0.112 & 1.110 & 0.027 & 572.748 & 0.053 & 0.00005 & 11.1 & 8.4 & 2 \\
\hline OF-11 & 0.011 & 0.001 & 0.003 & 0.819 & 0.047 & 0.016 & 0.127 & 1.110 & 0.027 & 591.947 & 0.049 & 0.00020 & 11.1 & 8.5 & 2 \\
\hline $60 \mathrm{WL}$ & 0.011 & 0.001 & 0.003 & 0.007 & 0.011 & 0.016 & 0.081 & 1.110 & 0.027 & 185.106 & 0.046 & 0.00005 & 11.7 & 8.7 & 2 \\
\hline TCLP & 5.0 & $b$ & 1.0 & 5.0 & $b$ & 5.0 & 1.0 & $b$ & $b$ & $b$ & $b$ & 0.2 & & & \\
\hline UTS & 0.300 & 0.014 & 0.190 & 0.860 & 5.000 & 0.370 & 0.160 & $b$ & 0.078 & $b$ & 5.300 & 0.025 & & & \\
\hline
\end{tabular}

${ }^{a} \mathrm{pH} 1$ is the initial $\mathrm{pH}$ check of the raw sample as specified in the TCLP. pH2 is the pH fo the TCLP extract after the 18-h extraction per TCLP.

${ }^{b}$ No standard specified in RCRA. 
Table 5. Overall weighted average surrogate sludge: grout density and grout/sludge volume ratio results for the screening tests

\begin{tabular}{|c|c|c|c|c|}
\hline Grout no. & $\begin{array}{l}\text { Sludge loading } \\
\text { (wt \%) }\end{array}$ & $\begin{array}{c}\text { Sludge water } \\
\text { (wt \%) }\end{array}$ & $\begin{array}{c}\text { Grout density } \\
(\mathrm{g} / \mathrm{mL})\end{array}$ & $\begin{array}{c}\text { Grout/sludge volume } \\
\text { ratio }\end{array}$ \\
\hline Surrogate sludge & 100.0 & 58.7 & 1.32 & $\mathrm{NA}^{a}$ \\
\hline O-01 & 55.0 & 58.7 & 1.69 & 1.41 \\
\hline O-02 & 55.0 & 58.7 & 1.73 & 1.38 \\
\hline $0-03$ & 60.0 & 58.7 & 1.64 & 1.34 \\
\hline $0-04$ & 65.0 & 58.7 & 1.61 & 1.26 \\
\hline O-05 & 70.0 & 58.7 & 1.56 & 1.21 \\
\hline O-06 & 55.0 & 58.7 & 1.73 & 1.38 \\
\hline O-07 & 55.0 & 58.7 & 1.71 & 1.40 \\
\hline OA-1 & 60.0 & 55.6 & 1.69 & 1.33 \\
\hline $\mathrm{OA}-2$ & 65.0 & 51.3 & 1.69 & 1.27 \\
\hline $\mathrm{OA}-3$ & 70.0 & 47.6 & 1.68 & 1.22 \\
\hline $\mathrm{OA}-4$ & 75.0 & 44.4 & 1.67 & 1.18 \\
\hline $\mathrm{OA}-5$ & 80.0 & 41.7 & 1.68 & 1.13 \\
\hline OA-6 & 85.0 & 41.7 & 1.68 & 1.06 \\
\hline OA-7 & 90.0 & 37.0 & 1.67 & 1.05 \\
\hline OB-1 & 60.0 & 54.1 & 1.71 & 1.33 \\
\hline OB-2 & 60.0 & 55.6 & 1.70 & 1.32 \\
\hline OB-3 & 60.0 & 57.4 & 1.67 & 1.32 \\
\hline OB-4 & 60.0 & 59.1 & 1.65 & 1.33 \\
\hline OB-5 & 60.0 & 60.8 & 1.65 & 1.31 \\
\hline OB-6 & 60.0 & 62.5 & 1.63 & 1.30 \\
\hline OB-7 & 60.0 & 64.0 & 1.62 & 1.30 \\
\hline OB-8 & 60.0 & 65.7 & 1.61 & 1.29 \\
\hline OC-1 & 55.0 & 58.7 & 1.68 & 1.43 \\
\hline $\mathrm{OC}-2$ & 60.0 & 58.7 & 1.65 & 1.33 \\
\hline OC-3 & 65.0 & 58.7 & 1.55 & 1.31 \\
\hline OC-4 & 55.0 & 58.7 & 1.73 & 1.38 \\
\hline OC-5 & 60.0 & 58.7 & 1.67 & 1.31 \\
\hline OC-6 & 65.0 & 58.7 & 1.63 & 1.24 \\
\hline OD-1 & 55.0 & 58.7 & 1.76 & 1.36 \\
\hline OD-2 & 55.0 & 58.7 & 1.75 & 1.37 \\
\hline OD-3 & 60.0 & 58.7 & 1.69 & 1.30 \\
\hline OD-4 & 60.0 & 58.7 & 1.71 & 1.28 \\
\hline OF-1 & 65.0 & 57.7 & 1.60 & 1.28 \\
\hline OF-2 & 65.0 & 51.3 & 1.43 & 1.50 \\
\hline OF-3 & 65.0 & 44.0 & 1.74 & 1.31 \\
\hline $\mathrm{OF}-4$ & 70.0 & 58.8 & 1.56 & 1.20 \\
\hline $\mathrm{OF}-5$ & 70.0 & 53.6 & 1.62 & 1.21 \\
\hline OF-6 & 70.0 & 47.6 & 1.66 & 1.24 \\
\hline OF-7 & 70.0 & 40.8 & 1.74 & 1.25 \\
\hline OF-8 & 75.0 & 54.9 & 1.62 & 1.11 \\
\hline OF-9 & 75.0 & 50.0 & 1.66 & 1.13 \\
\hline OF-10 & 75.0 & 44.4 & 1.66 & 1.18 \\
\hline OF-11 & 75.0 & 38.1 & 1.73 & 1.21 \\
\hline $60 \mathrm{WL}$ & 60.0 & 58.7 & 1.66 & 1.32 \\
\hline
\end{tabular}

${ }^{2}$ Not applicable. 
Table 6. Grout compositions for sensitivity testing of surrogate sludges

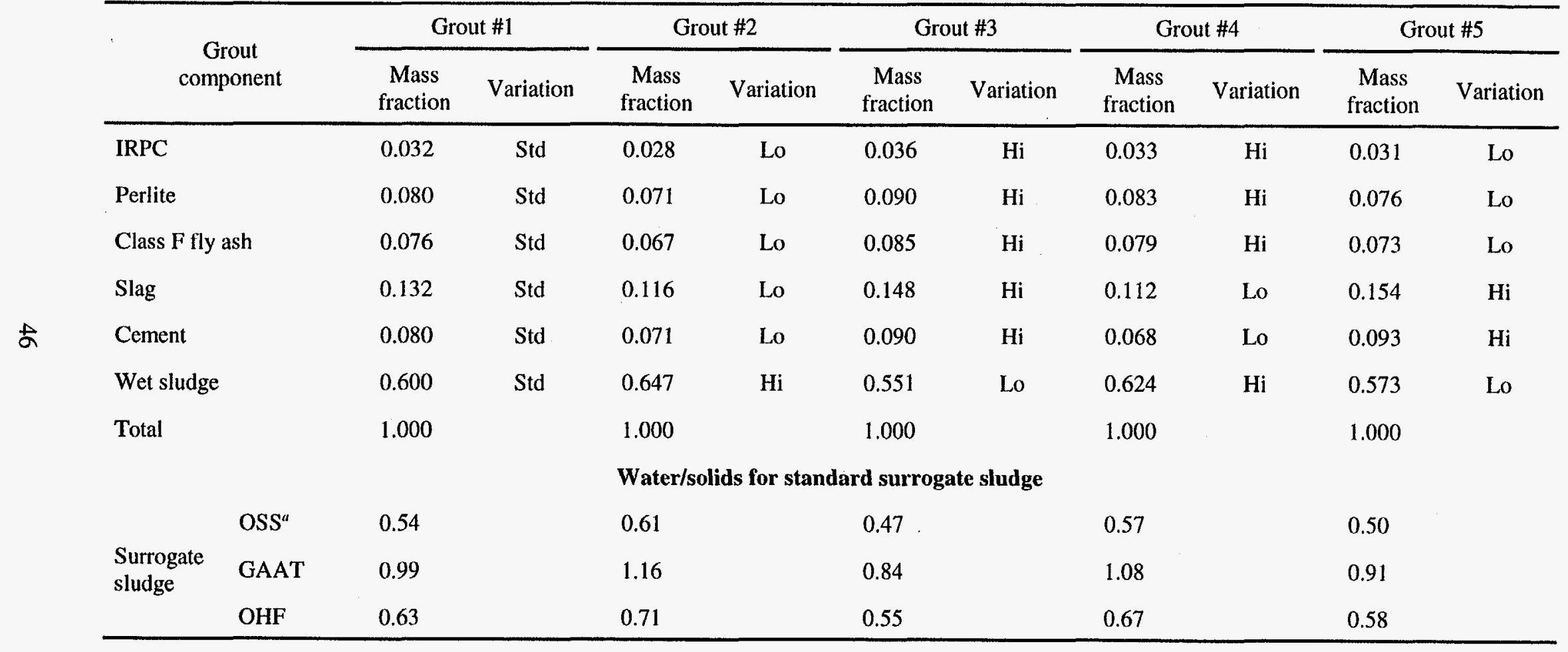

aOverall weighted average surrogate sludge. 
Table 7. Surrogate recipes for the sensitivity tests: overall average composition of ORNL tank sludges (OHF, GAAT, BVEST, and MVST)

\begin{tabular}{|c|c|c|c|}
\hline \multirow[b]{2}{*}{ Compound } & \multicolumn{3}{|c|}{ Wet surrogate sludge composition $(\mathrm{mg} / \mathrm{kg}$ ) } \\
\hline & Weighted average & Maximum water & $\begin{array}{l}\text { Minimum water }+ \\
\text { maximum bad actors }\end{array}$ \\
\hline \multicolumn{4}{|c|}{ RCRA metals } \\
\hline $\mathrm{Ag}_{2} \mathrm{O}$ & 7 & 2 & 54 \\
\hline $\mathrm{CdO}$ & 17 & 4 & 48 \\
\hline $\mathrm{Na}_{2} \mathrm{Cr}_{2} \mathrm{O}_{7} \cdot 2 \mathrm{H}_{2} \mathrm{O}$ & 680 & 181 & 6,877 \\
\hline $\mathrm{HgCl}_{2}$ & 84 & 22 & 792 \\
\hline $\mathrm{PbO}$ & 588 & 157 & 7,885 \\
\hline $\mathrm{SeO}_{2}$ & 26 & 7 & 121 \\
\hline $\mathrm{TINO}_{3}$ & 15 & 4 & 98 \\
\hline $\mathrm{ZnO}$ & 460 & 123 & 1,369 \\
\hline \multicolumn{4}{|c|}{ Process metals, salts, and organics } \\
\hline $\mathrm{Al}(\mathrm{OH})_{3}$ & 21,181 & 5,644 & 29,761 \\
\hline $\mathrm{Ca}(\mathrm{OH})_{2}$ & 4,282 & 1,141 & 6,017 \\
\hline $\mathrm{Fe}_{2} \mathrm{O}_{3}$ & 5,432 & 1,447 & 7,632 \\
\hline $\mathrm{KNO}_{3}$ & 22,957 & 6,118 & 32,257 \\
\hline $\mathrm{MgO}$ & 10,997 & 2,930 & 15,452 \\
\hline $\mathrm{Na}_{3} \mathrm{PO}_{4} \cdot 12 \mathrm{H}_{2} \mathrm{O}$ & 35,017 & 9,331 & 110,646 \\
\hline $\mathrm{SiO}_{2}$ & 10,638 & 2,835 & 14,948 \\
\hline $\mathrm{Sr}(\mathrm{NO} 3) 2$ & 412 & 110 & 579 \\
\hline $\mathrm{Th}\left(\mathrm{NO}_{3}\right)_{4} \cdot 4 \mathrm{H}_{2} \mathrm{O}$ & 25,146 & 6,701 & 35,333 \\
\hline $\mathrm{UO}_{2}\left(\mathrm{NO}_{3}\right)_{2} \cdot 6 \mathrm{H}_{2} \mathrm{O}$ & 47,243 & 12,590 & 66,381 \\
\hline $\mathrm{NaBr}$ & 251 & 67 & 4,224 \\
\hline $\mathrm{NaCl}$ & 2,919 & 778 & 6,123 \\
\hline $\mathrm{NaF}$ & 1,322 & 352 & 26,300 \\
\hline $\mathrm{NaNO}_{3}$ & 113,493 & 30,244 & 3,336 \\
\hline $\mathrm{NaNO}_{2}$ & 4,599 & 1,226 & 6,462 \\
\hline $\mathrm{Na}_{2} \mathrm{SO}_{4}$ & 4,044 & 1,078 & 13,899 \\
\hline Calcium oxalate & 1,451 & 387 & 9,146 \\
\hline Tributylphosphate & 9,733 & 2,594 & 60,052 \\
\hline $\mathrm{CaCO}_{3}$ & 81,280 & 21,660 & 114,207 \\
\hline $\mathrm{NaOH}$ & 8,508 & 2,267 & 0 \\
\hline Subtotal & 412,783 & 110,000 & 580,000 \\
\hline \multicolumn{4}{|c|}{ Mass fraction } \\
\hline Compounds & 0.413 & 0.110 & 0.580 \\
\hline Added water & 0.587 & 0.890 & 0.420 \\
\hline
\end{tabular}


Table 8. Overall weighted average tank sludge sensitivity test results: measured bulk grout densities and calculated grout/sludge volume ratios

\begin{tabular}{lcccl}
\hline Overall surrogate sludge & Grout no. & $\begin{array}{c}\text { Grout density } \\
(\mathrm{g} / \mathrm{mL})\end{array}$ & $\begin{array}{c}\text { Grout/sludge } \\
\text { volume ratio }\end{array}$ & \multicolumn{1}{c}{ Consistency } \\
\hline & 1 & 1.61 & 1.36 & Good \\
Standard & 2 & 1.57 & 1.29 & Little fluid \\
& 3 & 1.65 & 1.45 & Very dry and thick \\
& 4 & 1.60 & 1.32 & Good \\
Minimum water + & 5 & 1.65 & 1.39 & Little thick \\
maximum bad actors & 1 & 1.64 & 1.54 & More water added to make \\
Maximum water & 1 & 1.39 & 1.28 & Liquidy \\
\hline
\end{tabular}

Table 9. Overall weighted average tank sludge sensitivity test results: measured free water

\begin{tabular}{lcccc}
\hline \multirow{2}{*}{ Overall surrogate sludge } & Grout no. & \multicolumn{3}{c}{ Free water (vol\%) } \\
\cline { 3 - 5 } & 1 & $1 \mathrm{~d}$ & $7 \mathrm{~d}$ & $28 \mathrm{~d}$ \\
\hline \multirow{3}{*}{ Standard } & 2 & 0.2 & 0.0 & 0.0 \\
& 3 & 0.8 & 0.0 & 0.0 \\
& 4 & 0.0 & 0.0 & 0.0 \\
Minimum water + & 5 & 0.8 & 0.0 & 0.0 \\
maximum bad actors & 1 & 0.2 & 0.0 & 0.0 \\
Maximum water & & 0.0 & 0.0 & 0.0 \\
\hline
\end{tabular}

Table 10. Overall weighted average tank sludge sensitivity test results: unconfined compressive strengths

\begin{tabular}{lcrrr}
\hline \multirow{2}{*}{ Overall surrogate sludge } & Grout no. & \multicolumn{3}{c}{ Unconfined compressive strength (psi) } \\
\cline { 3 - 5 } & 1 & 1,183 & 1,164 & \multicolumn{1}{c}{3} \\
\hline \multirow{3}{*}{ Standard } & 2 & 784 & 839 & 1,120 \\
& 3 & 1,916 & 1,971 & 1,951 \\
& 4 & 1,040 & 1,035 & 1,030 \\
Minimum water + & 5 & 2,040 & 2,081 & 2,085 \\
maximum bad actors & 1 & 2,680 & 2,723 & 2,693 \\
Maximum water & 1 & & & \\
\hline
\end{tabular}


Table 11. Overall weighted average tank sludge sensitivity test results: TCLP extract concentrations

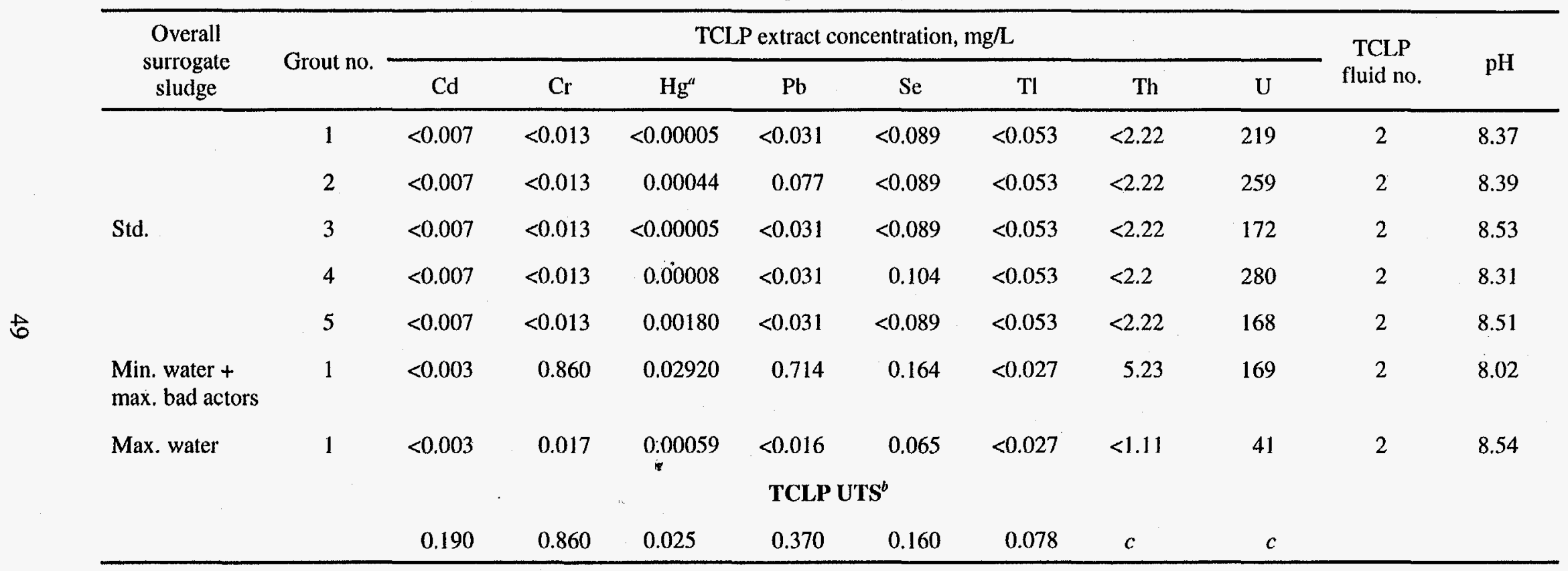

"Measured by cold vapor atomic absorption; all other extract concentrations were measured by ICP.

${ }^{b}$ The Universal Treatment Standard limits for the TCLP extract concentration.

${ }^{c}$ No standard specified in RCRA. 
Table 12. Overall weighted average tank sludge sensitivity test results: Leachability indexes of ${ }^{85} \mathrm{Sr}$ and ${ }^{137} \mathrm{Cs}$

\begin{tabular}{lccc}
\hline \multirow{2}{*}{ Overall surrogate sludge } & Grout no. & \multicolumn{2}{c}{ Leachability index } \\
\cline { 3 - 4 } & 1 & ${ }^{85} \mathrm{Sr}$ & ${ }^{137} \mathrm{Cs}$ \\
\hline \multirow{3}{*}{ Standard } & 2 & $10.1^{a}$ & $11.1^{a}$ \\
& 3 & 9.9 & 10.4 \\
& 4 & 10.1 & 10.9 \\
Minimum water + & 5 & 10.1 & 10.7 \\
maximum bad actors & 1 & 10.2 & 10.8 \\
Maximum water & 1 & 10.2 & 10.3 \\
\hline
\end{tabular}

${ }^{a}$ Average of three. 
Table 13. GAAT surrogate sludge: grout compositions for the screening tests

\begin{tabular}{|c|c|c|c|c|c|c|c|c|}
\hline \multirow{2}{*}{ Grout ID } & \multicolumn{5}{|c|}{ Dry blend (wt \%) } & \multirow{2}{*}{$\begin{array}{l}\text { Wet sludge } \\
\text { loading } \\
\text { (wt } \%)\end{array}$} & \multirow{2}{*}{ Water/solids } & \multirow{2}{*}{ Consistency } \\
\hline & IRPC & Perlite & Fly ash & Slag & Cement & & & \\
\hline GAAT-1 & 3.60 & 9.00 & 8.55 & 14.85 & 9.00 & 55.00 & 0.67 & Little thick \\
\hline GAAT-2 & 3.20 & 8.00 & 7.60 & 13.20 & 8.00 & 60.00 & 0.77 & Good \\
\hline GAAT-3 & 2.80 & 7.00 & 6.65 & 11.55 & 7.00 & 65.00 & 0.90 & Fluid \\
\hline GAAT-4 & 2.40 & 6.00 & 5.70 & 9.90 & 6.00 & 70.00 & 1.04 & Quite soupy \\
\hline GAAT-6 & 1.60 & 4.00 & 3.80 & 6.60 & 4.00 & 80.00 & 1.39 & Very soupy \\
\hline GAAT-7 & 2.00 & 5.00 & 4.75 & 8.25 & 5.00 & 75.00 & 0.90 & Fluid \\
\hline GAAT-8 & 1.60 & 4.00 & 3.80 & 6.60 & 4.00 & 80.00 & 0.90 & Fluid \\
\hline GAAT-9 & 1.20 & 3.00 & 2.85 & 4.95 & 3.00 & 85.00 & 0.90 & Fluid \\
\hline GAAT-13 & 1.20 & 3.00 & 2.85 & 4.95 & 3.00 & 85.00 & 0.75 & Very soupy \\
\hline GAAT-14 & 0.80 & 2.00 & 1.90 & 3.30 & 2.00 & 90.00 & 0.75 & Very soupy \\
\hline GAAT 60WL & 3.20 & 8.00 & 7.60 & 13.20 & 8.00 & 60.00 & 0.77 & Good \\
\hline
\end{tabular}


Table 14. GAAT surrogate sludge: free water and penetration resistance results for the screening tests

\begin{tabular}{lllcc}
\hline \multirow{2}{*}{ Grout ID } & \multicolumn{2}{c}{ Free water $($ vol \%) } & \multicolumn{2}{c}{ Penetration resistance (psi) } \\
\cline { 2 - 5 } \cline { 3 - 4 } GAAT-1 & $2 \mathrm{~d}$ & $7 \mathrm{~d}$ & $2 \mathrm{~d}$ & $7 \mathrm{~d}$ \\
\hline GAAT-2 & 0.00 & 0.00 & 4,800 & 8,000 \\
GAAT-3 & 0.00 & 0.00 & 2,320 & 4,720 \\
GAAT-4 & 0.00 & 0.00 & 1,440 & 3,200 \\
GAAT-5 & 0.00 & 0.00 & 1,360 & 2,240 \\
GAAT-6 & 0.00 & 0.00 & 440 & 1,040 \\
GAAT-7 & 1.01 & 0.81 & 240 & 400 \\
GAAT-8 & 0.00 & 0.00 & 600 & 1,360 \\
GAAT-9 & 0.00 & 0.00 & 200 & 440 \\
GAAT-10 & 0.00 & 0.00 & 40 & 200 \\
GAAT-12 & 1.60 & 1.60 & 0 & 40 \\
GAAT-13 & $\mathrm{NM}$ & 0.00 & $\mathrm{NM}$ & 720 \\
GAAT-14 & $\mathrm{NM}$ & 0.20 & $\mathrm{NM}$ & 320 \\
GAAT 60WL & $\mathrm{NM}$ & 0.20 & $\mathrm{NM}$ & 0 \\
\hline
\end{tabular}

${ }^{a}$ Not measured. 
Table 15. GAAT surrogate sludge: TCLP results for the screening tests

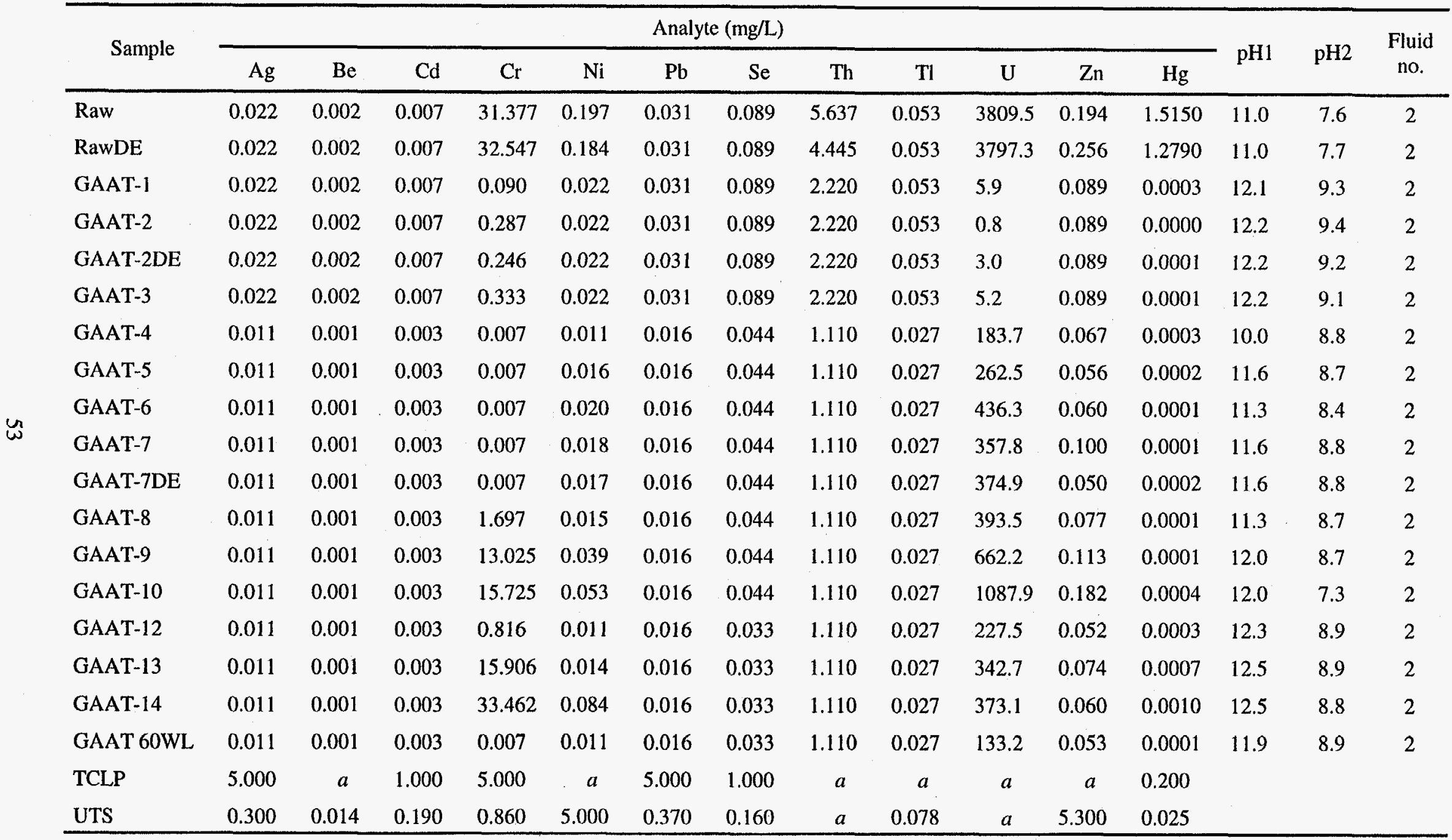

"No standard available from RCRA. 
Table 16. GAAT surrogate sludge: grout density and grout/sludge volume ratio results for the screening tests

\begin{tabular}{ccccc}
\hline Grout no. & $\begin{array}{c}\text { Sludge loading } \\
(\mathrm{wt} \%)\end{array}$ & $\begin{array}{c}\text { Sludge water } \\
\text { (wt \%) }\end{array}$ & $\begin{array}{c}\text { Grout density } \\
(\mathrm{g} / \mathrm{mL})\end{array}$ & $\begin{array}{c}\text { Grout/sludge } \\
\text { volume ratio }\end{array}$ \\
\hline Surrogate sludge & 100.0 & 72.7 & 1.23 & NA $^{a}$ \\
GAAT-1 & 55.0 & 72.7 & 1.59 & 1.42 \\
GAAT-2 & 60.0 & 72.7 & 1.54 & 1.34 \\
GAAT-3 & 65.0 & 72.7 & 1.51 & 1.26 \\
GAAT-4 & 70.0 & 72.7 & 1.44 & 1.23 \\
GAAT-5 & 75.0 & 72.7 & 1.40 & 1.17 \\
GAAT-6 & 80.0 & 72.7 & 1.37 & 1.13 \\
GAAT-7 & 75.0 & 63.2 & 1.50 & 1.20 \\
GAAT-8 & 80.0 & 59.2 & 1.50 & 1.16 \\
GAAT-9 & 85.0 & 55.7 & 1.49 & 1.14 \\
GAAT-10 & 90.0 & 52.6 & 1.50 & 1.11 \\
GAAT-12 & 80.0 & 53.6 & 1.26 & 1.46 \\
GAAT-13 & 85.0 & 50.4 & 1.26 & 1.42 \\
GAAT-14 & 90.0 & 47.6 & 1.52 & 1.15 \\
GAAT 60WL & 60.0 & 72.7 & 1.54 & 1.34 \\
\hline
\end{tabular}

${ }^{a}$ Not available. 
Table 17. Surrogate recipes for the sensitivity tests: Gunite and associated (GAAT) tank sludge

\begin{tabular}{|c|c|c|c|}
\hline \multirow{2}{*}{ Compound } & \multicolumn{3}{|c|}{ Wet surrogate sludge composition (mg/kg) } \\
\hline & Average $^{a}$ & Minimum water & $\begin{array}{l}\text { Minimum water }+ \\
\text { maximum bad actors }\end{array}$ \\
\hline \multicolumn{4}{|c|}{ RCRA metals } \\
\hline $\mathrm{Ag}_{2} \mathrm{O}$ & 0 & 0 & 0 \\
\hline $\mathrm{CdO}$ & 0 & 0 & 0 \\
\hline $\mathrm{Na}_{2} \mathrm{Cr}_{2} \mathrm{O}_{7} \cdot 2 \mathrm{H}_{2} \mathrm{O}$ & 1,284 & 1,990 & 6,877 \\
\hline $\mathrm{HgCl}_{2}$ & 124 & 192 & 563 \\
\hline $\mathrm{PbO}$ & 1,423 & 2,206 & 7,885 \\
\hline $\mathrm{SeO}_{2}$ & 0 & 0 & 0 \\
\hline $\mathrm{TINO}_{3}$ & 0 & 0 & 0 \\
\hline $\mathrm{ZnO}$ & 0 & 0 & 0 \\
\hline \multicolumn{4}{|c|}{ Process metals, salts, and organics } \\
\hline $\mathrm{Al}(\mathrm{OH})_{3}$ & 43,431 & 67,352 & 67,352 \\
\hline $\mathrm{Ca}(\mathrm{OH})_{2}$ & 21,211 & 32,893 & 32,893 \\
\hline $\mathrm{Fe}_{2} \mathrm{O}_{3}$ & 10,975 & 17,020 & 17,020 \\
\hline $\mathrm{K}_{2} \mathrm{CO}_{3}$ & 7,829 & 12,141 & 12,141 \\
\hline $\mathrm{MgO}$ & 4,790 & 7,429 & 7,429 \\
\hline $\mathrm{NaOH}$ & 20,750 & 32,178 & 32,178 \\
\hline $\mathrm{Na}_{2} \mathrm{CO}_{3}$ & 24,026 & 37,259 & 37,259 \\
\hline $\mathrm{SiO}_{2}$ & 7,888 & 12,232 & 12,232 \\
\hline $\mathrm{Th}\left(\mathrm{NO}_{3}\right)_{4} \cdot 4 \mathrm{H}_{2} \mathrm{O}$ & 17,546 & 27,209 & 27,209 \\
\hline $\mathrm{UO}_{2}\left(\mathrm{NO}_{3}\right)_{2} \cdot 6 \mathrm{H}_{2} \mathrm{O}$ & 89,585 & 138,926 & 96,068 \\
\hline $\mathrm{NaCl}$ & 1,716 & 2,660 & 4,540 \\
\hline $\mathrm{NaF}$ & 4,470 & 6,931 & 26,300 \\
\hline Tributylphosphate & 8,372 & 12,982 & 22,153 \\
\hline $\mathrm{Na}_{2} \mathrm{SO}_{4}$ & 7,994 & 12,398 & 13,899 \\
\hline Subtotal & 273,413 & 42,400 & 424,000 \\
\hline \multicolumn{4}{|c|}{ Mass fraction } \\
\hline Compounds & 0.273 & 0.424 & 0.424 \\
\hline Added water & 0.727 & 0.576 & 0.576 \\
\hline
\end{tabular}

${ }^{\sigma}$ Based on Savannah River Site surrogate GAAT sludge concentrations corrected to total $100 \%$. 
Table 18. GAAT sludge sensitivity test results: measured bulk grout densities and calculated grout/sludge volume ratio

\begin{tabular}{lcccl}
\hline GAAT surrogate sludge & Grout no. & $\begin{array}{c}\text { Grout gensity } \\
(\mathrm{g} / \mathrm{mL})\end{array}$ & $\begin{array}{c}\text { Grout/sludge } \\
\text { volume ratio }\end{array}$ & Consistency \\
\hline & 1 & 1.53 & 1.35 & Good \\
Standard & 2 & 1.48 & 1.29 & Fluid \\
& 3 & 1.58 & 1.42 & Thick \\
& 4 & 1.51 & 1.31 & Good \\
Minimum water + & 5 & 1.56 & 1.38 & Good \\
maximum bad actors & 1 & 1.66 & 1.42 & Very thick \\
Minimum water & 1 & 1.65 & 1.43 & Very thick \\
\hline
\end{tabular}

Table 19. GAAT sludge sensitivity test results: measured free water

\begin{tabular}{lcccc}
\hline \multirow{2}{*}{ GAAT surrogate sludge } & Grout no. & \multicolumn{3}{c}{ Free water (vol\%) } \\
\cline { 3 - 5 } & 1 & 0.0 & $7 \mathrm{~d}$ & $28 \mathrm{~d}$ \\
\hline \multirow{3}{*}{ Standard } & 2 & 0.0 & 0.0 & 0.0 \\
& 3 & 0.0 & 0.0 & 0.0 \\
& 4 & 0.0 & 0.0 & 0.0 \\
Minimum water + & 5 & 0.0 & 0.0 & 0.0 \\
maximum bad actors & 1 & 0.0 & 0.0 & 0.0 \\
Minimum water & & & 0.0 & 0.0 \\
\hline
\end{tabular}

Table 20. GAAT sludge sensitivity test results: unconfined compressive strengths

\begin{tabular}{lcccc}
\hline \multirow{2}{*}{ GAAT surrogate sludge } & Grout no. & \multicolumn{3}{c}{ Unconfined compressive strength (psi) } \\
\cline { 3 - 5 } & 1 & 1 & 2 & 3 \\
\hline \multirow{3}{*}{ Standard } & 2 & 753 & 716 & 712 \\
& 3 & 393 & 440 & 441 \\
& 4 & 415 & 919 & 955 \\
Minimum water + & 5 & 487 & 514 & 537 \\
maximum bad actors & 1 & 1,061 & 1,032 & 1,062 \\
Minimum water & 1 & 1,351 & 1,371 & 1,398 \\
\hline
\end{tabular}


Table 21. GAAT sludge sensitivity test results: TCLP extract concentrations

\begin{tabular}{|c|c|c|c|c|c|c|c|c|c|c|c|}
\hline \multirow{2}{*}{$\begin{array}{c}\text { GAAT } \\
\text { surrogate } \\
\text { sludge }\end{array}$} & \multirow{2}{*}{ Grout no. } & \multicolumn{8}{|c|}{ TCLP extract concentration (mg/L) } & \multirow{2}{*}{$\begin{array}{c}\text { TCLP } \\
\text { fluid no. }\end{array}$} & \multirow{2}{*}{$\mathrm{pH}$} \\
\hline & & $\mathrm{Cd}$ & $\mathrm{Cr}$ & $\mathrm{Hg}^{\prime \prime}$ & $\mathrm{Pb}$ & $\mathrm{Se}$ & $\mathrm{TI}$ & $\mathrm{Th}$ & $\mathrm{U}$ & & \\
\hline \multirow{4}{*}{ Std. } & 1 & $<0.003$ & 0.072 & $<0.00005$ & 0.041 & 0.045 & $<0.027$ & 3.41 & 162 & 2 & 8.60 \\
\hline & 2 & $<0.003$ & 0.086 & $<0.00005$ & 0.042 & 0.054 & $<0.027$ & 3.91 & 183 & 2 & 8.66 \\
\hline & 3 & $<0.003$ & 0.074 & $<0.00005$ & 0.051 & 0.056 & $<0.027$ & 3.82 & 174 & 2 & 8.56 \\
\hline & 4 & $<0.003$ & 0.092 & $<0.00005$ & 0.067 & 0.062 & $<0.027$ & 4.91 & 249 & 2 & 8.45 \\
\hline & 5 & $<0.003$ & 0.063 & 0.00068 & 0.058 & $<0.044$ & $<0.027$ & 2.65 & 125 & 2 & 8.73 \\
\hline $\begin{array}{l}\text { Min. water } \\
+ \text { max. bad } \\
\text { actors }\end{array}$ & 1 & $<0.003$ & 11.030 & $<0.00005$ & 0.064 & $<0.044$ & $<0.027$ & 4.37 & 208 & 2 & 8.64 \\
\hline Min. water & 1 & $<0.003$ & 0.137 & $<0.00005$ & 0.087 & 0.084 & $<0.027$ & 7.38 & 378 & 2 & 8.47 \\
\hline \multicolumn{12}{|c|}{ TCLP UTS $^{b}$} \\
\hline & & 0.190 & 0.860 & 0.025 & 0.370 & 0.160 & 0.078 & $\mathrm{NA}^{c}$ & $\mathrm{NA}^{c}$ & & \\
\hline
\end{tabular}

${ }^{a}$ Measured by cold vapor atomic absorption; all other extract concentrations were measured by ICP.

${ }^{b}$ The Universal Treatment Standard limits for the TCLP extract concentration.

Not available. 
Table 22. GAAT sludge sensitivity test results: leachability indexes of ${ }^{85} \mathrm{Sr}$ and ${ }^{137} \mathrm{Cs}$

\begin{tabular}{lccc}
\hline \multirow{2}{*}{ GAAT surrogate sludge } & Grout no. & \multicolumn{2}{c}{ Leachability index } \\
\cline { 3 - 4 } & 1 & ${ }^{85} \mathrm{Sr}$ & ${ }^{137} \mathrm{Cs}$ \\
\hline & 2 & $10.4^{a}$ & $11.1^{a}$ \\
Standard & 3 & 10.5 & 11.1 \\
& 4 & 9.9 & 8.2 \\
Minimum water + & 5 & 10.5 & 11.6 \\
maximum bad actors & 1 & 10.2 & 11.4 \\
Minimum water & 1 & 10.7 & 11.0 \\
\hline
\end{tabular}

average of three. 
Table 23. Old hydrofracture surrogate sludge: grout compositions for the screening tests

\begin{tabular}{|c|c|c|c|c|c|c|c|c|c|c|}
\hline & \multirow{2}{*}{ Grout ID } & \multicolumn{5}{|c|}{ Dry blend (wt $\%$ ) } & \multirow{2}{*}{$\begin{array}{l}\text { Wet sludge } \\
\text { loading } \\
\text { (wt } \%)\end{array}$} & \multirow{2}{*}{ Water/solids } & \multirow{2}{*}{ Consistency } & \multirow{2}{*}{$\begin{array}{l}\mathrm{pH} \text { of } \\
\text { sludge }\end{array}$} \\
\hline & & IRPC & Perlite & Fly ash & Slag & Cement & & & & \\
\hline \multirow{2}{*}{$\begin{array}{l}\text { Using } \\
\text { Th( }\left(\mathrm{NO}_{3}\right)_{4} \text { in } \\
\text { lieu of } \mathrm{ThO}_{2}\end{array}$} & $\mathrm{OHF}-1 \mathrm{~A}$ & 3.60 & 9.00 & 8.55 & 14.85 & 9.00 & 55.00 & 0.55 & Thick & \\
\hline & OHF-3A & 2.80 & 7.00 & 6.65 & 11.55 & 7.00 & 65.00 & 0.72 & Good & \\
\hline \multirow{6}{*}{$\begin{array}{l}\text { Standard } \\
\text { surrogate }\end{array}$} & OHF-2 & 3.20 & 8.00 & 7.60 & 13.20 & 8.00 & 60.00 & 0.63 & Good & \\
\hline & OHF-3 & 2.80 & 7.00 & 6.65 & 11.55 & 7.00 & 65.00 & 0.72 & Fluid & \\
\hline & OHF-4 & 2.54 & 6.34 & 6.02 & 10.46 & 6.34 & 68.30 & 0.91 & Soupy & \\
\hline & OHF-5 & 3.60 & 4.50 & 8.55 & 14.85 & 13.50 & 55.00 & 0.55 & Good & 11.7 \\
\hline & OHF-8 & 3.53 & 8.82 & 8.38 & 14.55 & 8.82 & 55.92 & 0.53 & Good & 13.6 \\
\hline & OHF-60WL & 3.20 & 8.00 & 7.60 & 13.20 & 8.00 & 60.00 & 0.57 & Good & \\
\hline
\end{tabular}


Table 24. Old hydrofracture surrogate sludge: free water and penetration resistance results for the screening tests

\begin{tabular}{lccrrr}
\hline \multirow{2}{*}{ Grout ID } & \multicolumn{2}{c}{ Free water $($ vol \%) } & & \multicolumn{3}{c}{ Penetration resistance (psi) } \\
\cline { 2 - 3 } \cline { 5 - 6 } OHF-1A & $2 \mathrm{~d}$ & $7 \mathrm{~d}$ & $2 \mathrm{~d}$ & $7 \mathrm{~d}$ & $28 \mathrm{~d}$ \\
OHF-2A & 0.40 & 0.00 & 320 & 8,000 & $\mathrm{NM}^{a}$ \\
OHF-3A & 1.20 & 0.00 & 0 & 3,600 & $\mathrm{NM}$ \\
OHF-4A & 1.61 & 0.40 & 0 & 760 & $\mathrm{NM}$ \\
OHF-1 & 1.60 & 0.40 & 0 & 80 & $\mathrm{NM}$ \\
OHF-2 & 0.00 & 0.00 & 0 & 0 & 0 \\
OHF-3 & 0.00 & 0.00 & 0 & 0 & 0 \\
OHF-4 & 0.40 & 0.20 & 0 & 0 & 0 \\
OHF-5 & 0.80 & 0.80 & 0 & 960 & 1,000 \\
OHF-6 & 0.00 & 0.00 & 0 & 7,200 & NM \\
OHF-7 & 0.60 & 0.00 & 240 & 8,000 & NM \\
OHF-8 & 1.40 & 0.60 & 3,320 & 5,200 & NM \\
OHF-60WL & 0.00 & 0.00 & 5,160 & 7,280 & NM \\
\hline
\end{tabular}

${ }^{a}$ Not measured. 
Table 25. Old hydrofracture surrogate sludge: TCLP results for the screening tests

\begin{tabular}{|c|c|c|c|c|c|c|c|c|c|c|c|c|c|c|c|}
\hline \multirow{2}{*}{ Sample } & \multicolumn{12}{|c|}{ Analyte (mg/L) } & \multirow{2}{*}{$\mathrm{pH} 1$} & \multirow{2}{*}{$\mathrm{pH} 2$} & \multirow{2}{*}{$\begin{array}{c}\text { Fluid } \\
\text { no. }\end{array}$} \\
\hline & $\mathrm{Ag}$ & $\mathrm{Be}$ & $\mathrm{Cd}$ & $\mathrm{Cr}$ & $\mathrm{Ni}$ & $\mathrm{Pb}$ & $\mathrm{Se}$ & Th & $\mathrm{Tl}$ & U & $\mathrm{Zn}$ & $\mathrm{Hg}$ & & & \\
\hline Raw A & 0.011 & 0.001 & 0.530 & 14.313 & 0.011 & 0.496 & 0.044 & 1.110 & 0.027 & 0.245 & 4.780 & 11.73300 & 11.3 & 6.0 & 2 \\
\hline Raw ADE & 0.011 & 0.001 & 0.553 & 14.252 & 0.011 & 0.549 & 0.044 & 1.110 & 0.027 & 0.222 & 5.510 & 9.93000 & 11.3 & 5.9 & 2 \\
\hline $\mathrm{OHF}-1 \mathrm{~A}$ & 0.011 & 0.001 & 0.003 & 0.018 & 0.011 & 0.016 & 0.044 & 1.110 & 0.027 & 0.599 & 0.050 & 0.00005 & 11.7 & 9.3 & 2 \\
\hline $\mathrm{OHF}-2 \mathrm{~A}$ & 0.011 & 0.001 & 0.003 & 0.028 & 0.011 & 0.016 & 0.044 & 1.110 & 0.027 & 0.428 & 0.057 & 0.00005 & 11.8 & 9.4 & 2 \\
\hline OHF-2ADE & 0.011 & 0.001 & 0.003 & 0.034 & 0.011 & 0.016 & 0.044 & 1.110 & 0.027 & 0.576 & 0.044 & 0.00005 & 11.8 & 9.4 & 2 \\
\hline OHF-3A & 0.011 & 0.001 & 0.003 & 0.022 & 0.011 & 0.016 & 0.044 & 1.110 & 0.027 & 6.411 & 0.053 & 0.00005 & 11.7 & 9.0 & 2 \\
\hline OHF-4A & 0.011 & 0.001 & 0.003 & 0.007 & 0.012 & 0.016 & 0.044 & 1.110 & 0.027 & 53.949 & 0.063 & 0.00005 & 11.8 & 8.7 & 2 \\
\hline Raw & 0.011 & 0.001 & 0.521 & 6.887 & 0.015 & 0.016 & 0.044 & 1.110 & 0.027 & 255.614 & 5.614 & 8.39400 & 9.2 & 5.8 & 2 \\
\hline RawDE & 0.011 & 0.001 & 0.629 & 7.106 & 0.025 & 0.016 & 0.044 & 1.110 & 0.027 & 262.470 & 6.121 & 8.97400 & 9.2 & 5.7 & 2 \\
\hline OHF-1 & 0.011 & 0.001 & 0.003 & 0.020 & 0.011 & 0.016 & 0.044 & 1.110 & 0.027 & 0.304 & 0.054 & 0.00005 & 11.6 & 9.7 & 2 \\
\hline OHF-2 & 0.011 & 0.001 & 0.003 & 0.011 & 0.012 & 0.016 & 0.044 & 1.110 & 0.027 & 5.918 & 0.066 & 0.00005 & 11.7 & 9.4 & 2 \\
\hline OHF-2 DE & 0.011 & 0.001 & 0.003 & 0.007 & 0.012 & 0.016 & 0.044 & 1.110 & 0.027 & 17.764 & 0.049 & 0.00005 & 11.7 & 9.3 & 2 \\
\hline OHF-3 & 0.011 & 0.001 & 0.003 & 0.007 & 0.017 & 0.016 & 0.044 & 1.110 & 0.027 & 94.639 & 0.049 & 0.00066 & 11.8 & 8.6 & 2 \\
\hline OHF-4 & 0.011 & 0.001 & 0.022 & 2.731 & 0.037 & 0.028 & 0.044 & 1.110 & 0.027 & 152.346 & 0.373 & 0.04690 & 12.1 & 6.4 & 2 \\
\hline OHF-5 & 0.011 & 0.001 & 0.003 & 0.007 & 0.011 & 0.016 & 0.033 & 1.110 & 0.027 & 41.732 & 0.044 & 0.00005 & 11.9 & 8.8 & 2 \\
\hline OHF-6 & 0.011 & 0.001 & 0.003 & 0.061 & 0.011 & 0.016 & 0.033 & 1.110 & 0.027 & 0.222 & 0.044 & 0.00005 & 12.3 & 10.6 & 2 \\
\hline $\begin{array}{l}\text { OHF-7 } \\
\text { (NaOH added) }\end{array}$ & 0.011 & 0.001 & 0.003 & 0.007 & 0.011 & 0.016 & 0.033 & 1.110 & 0.027 & 0.251 & 0.048 & 0.00008 & 12.5 & 9.9 & 2 \\
\hline $\begin{array}{l}\text { OHF-8 } \\
\text { (NaOH added) }\end{array}$ & 0.011 & 0.001 & 0.003 & 0.007 & 0.011 & 0.016 & 0.033 & 1.110 & 0.027 & 0.374 & 0.044 & 0.00009 & 12.4 & 9.7 & 2 \\
\hline OHF 60WL & 0.011 & 0.001 & 0.003 & 0.007 & 0.011 & 0.016 & 0.033 & 1.110 & 0.027 & 0.285 & 0.064 & 0.00005 & 12.3 & 9.6 & 2 \\
\hline TCLP & 5.000 & $a$ & 1.000 & 5.000 & $a$ & 5.000 & 1.000 & $a$ & $a$ & $a$ & $a$ & 0.200 & & & \\
\hline UTS & 0.300 & 0.014 & 0.190 & 0.860 & 5.000 & 0.370 & 0.160 & $a$ & 0.078 & $a$ & 5.300 & 0.025 & & & \\
\hline
\end{tabular}

"No standard specified in RCRA. 
Table 26. OHF surrogate sludge: grout density and grout/sludge volume ratio results for the screening tests

\begin{tabular}{lcccc}
\hline \multicolumn{1}{c}{ Grout no. } & $\begin{array}{c}\text { Sludge loading } \\
\text { (wt \%) }\end{array}$ & $\begin{array}{c}\text { Sludge water } \\
\text { (wt \%) }\end{array}$ & $\begin{array}{c}\text { Grout density } \\
(\mathrm{g} / \mathrm{mL})\end{array}$ & $\begin{array}{c}\text { Grout/sludge } \\
\text { volume ratio }\end{array}$ \\
\hline $\begin{array}{l}\text { Surrogate sludge A, } \\
\text { using thorium nitrate }\end{array}$ & 100.0 & 64.3 & 1.25 & NA $^{a}$ \\
OHF-1A & 55.0 & 64.3 & 1.63 & 1.39 \\
OHF-2A & 60.0 & 64.3 & 1.57 & 1.32 \\
OHF-3A & 65.0 & 64.3 & 1.53 & 1.25 \\
OHF-4A & 68.3 & 64.3 & 1.47 & 1.25 \\
Standard surrogate & 100.0 & 64.3 & 1.30 & NA \\
sludge & & & & 1.42 \\
OHF-1 & 55.0 & 64.3 & 1.67 & 1.33 \\
OHF-2 & 60.0 & 64.3 & 1.63 & 1.26 \\
OHF-3 & 65.0 & 64.3 & 1.59 & 1.37 \\
OHF-4 & 68.3 & 64.3 & 1.40 & 1.39 \\
OHF-5 & 55.0 & 64.3 & 1.70 & 1.41 \\
OHF-6 & 55.0 & 64.3 & 1.67 & 1.28 \\
OHF-7 & 60.5 & 64.3 & 1.68 & 1.37 \\
OHF-8 & 55.9 & 64.3 & 1.70 & 1.30 \\
OHF-60WL & 60.0 & 64.3 & 1.67 & \\
\hline
\end{tabular}

${ }^{a}$ Not available. 
Table 27. Surrogate recipes for the sensitivity tests: old hydrofracture (OHF) tank sludge

\begin{tabular}{|c|c|c|c|}
\hline \multirow[b]{2}{*}{ Compound } & \multicolumn{3}{|c|}{ Wet surrogate sludge composition $(\mathrm{mg} / \mathrm{kg})$} \\
\hline & Weighted average & Maximum water & $\begin{array}{l}\text { Minimum water }+ \\
\text { maximum bad actors }\end{array}$ \\
\hline \multicolumn{4}{|c|}{ RCRA metals } \\
\hline $\mathrm{Ag}_{2} \mathrm{O}$ & 0 & 0 & 0 \\
\hline $\mathrm{CdO}$ & 11 & 9 & 19 \\
\hline $\mathrm{Na}_{2} \mathrm{Cr}_{2} \mathrm{O}_{7} \cdot 2 \mathrm{H}_{2} \mathrm{O}$ & 281 & 219 & 691 \\
\hline $\mathrm{HgCl}_{2}$ & 151 & 117 & 792 \\
\hline $\mathrm{PbO}$ & 420 & 327 & 705 \\
\hline $\mathrm{SeO}_{2}$ & 0 & 0 & 0 \\
\hline $\mathrm{TINO}_{3}$ & 0 & 0 & 0 \\
\hline $\mathrm{ZnO}$ & 196 & 152 & 294 \\
\hline \multicolumn{4}{|c|}{ Process metals, salts, and organics } \\
\hline $\mathrm{Al}(\mathrm{OH})_{3}$ & 39,201 & 30,502 & 41,802 \\
\hline $\mathrm{CaCO}_{3}$ & 69,061 & 53,735 & 73,644 \\
\hline $\mathrm{Fe}_{2} \mathrm{O}_{3}$ & 7,035 & 5,474 & 7,502 \\
\hline $\mathrm{K}_{2} \mathrm{CO}_{3}$ & 5,483 & 4,266 & 5,847 \\
\hline $\mathrm{MgCO}_{3}$ & 9,054 & 7,045 & 9,655 \\
\hline $\mathrm{Na}_{3} \mathrm{PO}_{4} \cdot 12 \mathrm{H}_{2} \mathrm{O}$ & 56,983 & 44,337 & 80,788 \\
\hline $\mathrm{SiO}_{2}$ & 27,883 & 21,695 & 29,733 \\
\hline $\mathrm{Sr}\left(\mathrm{NO}_{3}\right)_{2}$ & 1,160 & 903 & 1,237 \\
\hline $\mathrm{ThO}_{2}$ & 92,275 & 71,797 & 36,726 \\
\hline $\mathrm{UO}_{2}\left(\mathrm{NO}_{3}\right)_{2} \cdot 6 \mathrm{H}_{2} \mathrm{O}$ & 20,258 & 15,762 & 21,602 \\
\hline $\mathrm{NaBr}$ & 31 & 24 & 90 \\
\hline $\mathrm{NaCl}$ & 761 & 592 & 5,710 \\
\hline $\mathrm{NaF}$ & 463 & 360 & 601 \\
\hline $\mathrm{NaNO}_{2}$ & 3,063 & 2,383 & 3,266 \\
\hline $\mathrm{Na}_{2} \mathrm{SO}_{4}$ & 2,096 & 1,631 & 4,377 \\
\hline Calcium oxalate & 129 & 100 & 137 \\
\hline Tributylphosphate & 17,503 & 13,618 & 51,737 \\
\hline $\mathrm{Na}_{2} \mathrm{CO}_{3}$ & 3,794 & 2,952 & 4,045 \\
\hline Subtotal & 357,290 & 278,000 & 381,000 \\
\hline \multicolumn{4}{|c|}{ Mass fraction } \\
\hline Compounds & 0.357 & 0.278 & 0.381 \\
\hline Added water & 0.643 & 0.722 & 0.619 \\
\hline
\end{tabular}


Table 28. OHF sludge sensitivity test results: measured bulk grout densities and calculated grout/sludge volume ratio

\begin{tabular}{lcccc}
\hline OHF surrogate sludge & Grout no. & $\begin{array}{c}\text { Grout density } \\
(\mathrm{g} / \mathrm{mL})\end{array}$ & $\begin{array}{c}\text { Grout/sludge } \\
\text { volume ratio }\end{array}$ & Consistency \\
\hline & 1 & 1.61 & 1.35 & Fluid \\
Standard & 2 & 1.57 & 1.28 & Fluid \\
& 3 & 1.65 & 1.43 & Thick \\
& 4 & 1.60 & 1.31 & Good \\
Minimum water + & 5 & 1.65 & 1.38 & Fluid \\
maximum bad actors & 1 & 1.59 & 1.40 & \\
Maximum water & 1 & 1.55 & 1.31 & Fluid \\
\hline
\end{tabular}

Table 29. OHF sludge sensitivity test results: measured free water

\begin{tabular}{lcccc}
\hline \multirow{2}{*}{ OHF surrogate sludge } & Grout no. & \multicolumn{3}{c}{ Free water (vol\%) } \\
\cline { 3 - 5 } & 1 & 1.6 & $7 \mathrm{~d}$ & $28 \mathrm{~d}$ \\
\hline \multirow{3}{*}{ Standard } & 2 & 2.0 & 0.6 & 0.4 \\
& 3 & 0.8 & 1.2 & 1.2 \\
& 4 & 1.6 & 0.0 & 0.0 \\
Minimum water + & 5 & 0.8 & 0.0 & 0.8 \\
maximum bad actors & 1 & 1.6 & 0.2 & 0.0 \\
Maximum water & & & & 0.2 \\
\hline
\end{tabular}

Table 30. OHF sludge sensitivity test results: unconfined compressive strengths

\begin{tabular}{lcccc}
\hline \multirow{2}{*}{ OHF surrogate sludge } & Grout no. & \multicolumn{3}{c}{ Unconfined compressive strength (psi) } \\
\cline { 3 - 5 } & 1 & 1 & 2 & 3 \\
\hline & 2 & 506 & 507 & 512 \\
Standard & 3 & 363 & 368 & 366 \\
& 4 & 880 & 903 & 883 \\
& 5 & 463 & 418 & 445 \\
Minimum water + & 1 & 820 & 807 & 865 \\
maximum bad actors & & 513 & 497 & 502 \\
Maximum water & 1 & & & \\
\hline
\end{tabular}


Table 31. OHF sludge sensitivity test results: TCLP extract concentrations

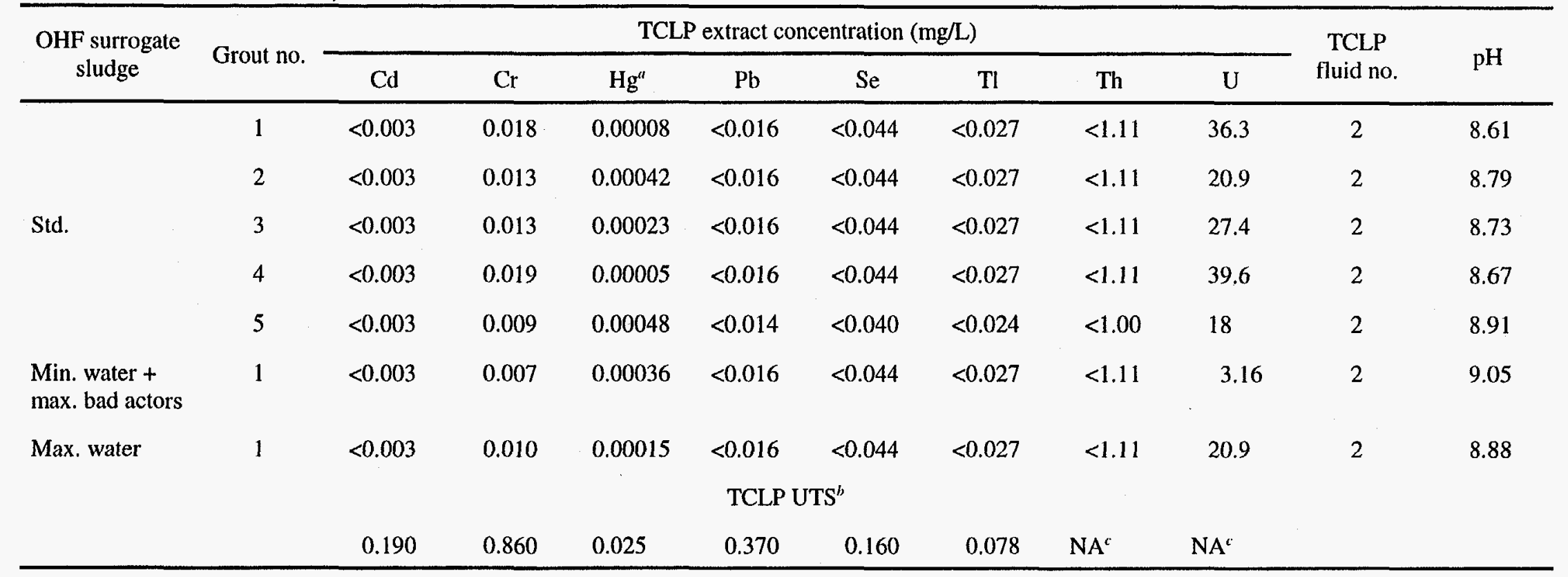

"Measured by cold vapor atomic absorption; all other extract concentrations were measured by ICP.

'The Universal Treatment Standard limits for the TCLP extract concentration.

"Not available. 
Table 32. OHF sludge sensitivity test results: leachability indexes of ${ }^{85} \mathrm{Sr}$ and ${ }^{137} \mathrm{Cs}$

\begin{tabular}{lccc}
\hline \multirow{2}{*}{ OHF surrogate sludge } & Grout no. & \multicolumn{2}{c}{ Leachability index } \\
\cline { 3 - 4 } & 1 & ${ }^{85} \mathrm{Sr}$ & ${ }^{137} \mathrm{Cs}$ \\
\hline & 2 & $11.3^{a}$ & $11.7^{a}$ \\
Standard & 3 & 11.4 & 11.6 \\
& 4 & 11.5 & 11.8 \\
Minimum water + & 5 & 11.3 & 12.1 \\
maximum bad actors & 1 & 12.5 & 11.8 \\
Maximum water & 1 & 11.2 & \\
\hline
\end{tabular}

${ }^{a}$ Average of three.

Table 33. Testing the standard dry blend at $55 \mathrm{wt} \%$ sludge loading varying the water content of the surrogate W25 sludge

\begin{tabular}{cccl}
\hline $\begin{array}{c}\text { Wet sludge water } \\
\text { content (wt \%) }\end{array}$ & $\begin{array}{c}\text { 6-d free water } \\
(\text { vol \%) }\end{array}$ & $\begin{array}{c}\text { 6-d penetration } \\
\text { resistance (psi) }\end{array}$ & \multicolumn{1}{c}{ Comments } \\
\hline $52^{a}$ & 0 & 8,000 & $\begin{array}{c}\text { Too dry at 45 wt \%, added water; still } \\
\text { very thick, too thick for hot cell }\end{array}$ \\
65 & 0 & 8,000 & Still quite thick \\
70 & 0 & 7,680 & \\
75 & 0 & 6,880 & Good consistency \\
80 & 0 & 7,120 & Fluid, but not soupy \\
85 & 0 & 7,360 & Acceptable fluidity, not too soupy \\
\hline
\end{tabular}

${ }^{a}$ Began as $45 \mathrm{wt} \%$ water content; added water increased wet sludge loading to $59 \mathrm{wt} \%$. 
Table 34. Chemical composition of actual W25 sludge

\begin{tabular}{|c|c|}
\hline Component & $\begin{array}{l}\text { Air-dried sludge solids } \\
\text { concentration, } \mathrm{mg} / \mathrm{g}^{a}\end{array}$ \\
\hline $\mathrm{Al}$ & 25.8 \\
\hline $\mathrm{Ba}$ & 0.5 \\
\hline $\mathrm{Ca}$ & 96.1 \\
\hline $\mathrm{Cd}$ & 0.06 \\
\hline $\mathrm{Co}$ & 0.04 \\
\hline $\mathrm{Cr}$ & 0.6 \\
\hline $\mathrm{Cs}$ & 0.0026 \\
\hline $\mathrm{Cu}$ & 0.3 \\
\hline $\mathrm{Fe}$ & 8.6 \\
\hline $\mathrm{Hg}$ & 0.2 \\
\hline $\mathrm{K}$ & 14.4 \\
\hline $\mathrm{Mg}$ & 13.5 \\
\hline $\mathrm{Mn}$ & 0.8 \\
\hline $\mathrm{Na}$ & 110 \\
\hline $\mathrm{Ni}$ & 0.4 \\
\hline $\mathrm{Pb}$ & 2.0 \\
\hline $\mathrm{Si}$ & 15.3 \\
\hline $\mathrm{Sr}$ & 0.56 \\
\hline Th & 57.4 \\
\hline $\mathrm{Tl}$ & 0.4 \\
\hline $\mathrm{U}^{b}$ & 27.6 \\
\hline $\mathrm{Zn}$ & 0.8 \\
\hline $\mathrm{Br}$ & 0.7 \\
\hline $\mathrm{Cl}^{-}$ & 3.7 \\
\hline$F^{-}$ & 1.9 \\
\hline $\mathrm{CO}_{3}{ }^{2-}$ & 115 \\
\hline $\mathrm{NO}_{3}^{-}$ & 179 \\
\hline $\mathrm{PO}_{4}{ }^{3-}$ & 29.5 \\
\hline $\mathrm{SO}_{4}^{2-}$ & 7.0 \\
\hline
\end{tabular}

${ }^{a}$ Analyses based upon centrifuged, wet sludge solids that were air-dried to constant weight.

\footnotetext{
${ }^{b} \mathrm{Wt} \%$ of uranium isotopes $\left({ }^{238} \mathrm{U}=99.28,{ }^{235} \mathrm{U}=0.57\right.$, ${ }^{234} \mathrm{U}=0.01$, and ${ }^{233} \mathrm{U}=0.14$ ).
} 
Table 35. Chemical composition of the surrogate sludge representing Tank W25

\begin{tabular}{|c|c|}
\hline Chemical component & Weight $(\mathrm{g})$ \\
\hline $\mathrm{Al}(\mathrm{OH})_{3}$ & 10.32 \\
\hline $\mathrm{Ba}(\mathrm{OH})_{2} \cdot 8 \mathrm{H}_{2} \mathrm{O}$ & 0.14 \\
\hline $\mathrm{Ca}(\mathrm{OH})_{2}$ & 4.90 \\
\hline $\mathrm{CdO}$ & 0.01 \\
\hline $\mathrm{Na}_{2} \mathrm{Cr}_{2} \mathrm{O}_{7} \cdot 2 \mathrm{H}_{2} \mathrm{O}$ & 0.24 \\
\hline $\mathrm{Fe}_{2} \mathrm{O}_{3}$ & 1.70 \\
\hline $\mathrm{HgCl}_{2}$ & 0.04 \\
\hline $\mathrm{KNO}_{3}$ & 5.15 \\
\hline $\mathrm{MgO}$ & 3.09 \\
\hline $\mathrm{NaOH}$ & 17.94 \\
\hline $\mathrm{NiO}$ & 0.07 \\
\hline $\mathrm{PbO}$ & 0.31 \\
\hline $\mathrm{SiO}_{2}$ & 4.53 \\
\hline $\mathrm{Sr}\left(\mathrm{NO}_{3}\right)_{2}$ & 1.87 \\
\hline $\operatorname{Th}\left(\mathrm{NO}_{3}\right)_{4} \cdot 4 \mathrm{H}_{2} \mathrm{O}$ & 18.80 \\
\hline $\mathrm{UO}_{2}\left(\mathrm{NO}_{3}\right)_{2} \cdot 6 \mathrm{H}_{2} \mathrm{O}$ & 8.05 \\
\hline $\mathrm{ZnO}$ & 0.14 \\
\hline $\mathrm{NaBr}$ & 0.13 \\
\hline $\mathrm{CaCO}_{3}$ & 26.52 \\
\hline $\mathrm{NaCl}$ & 0.83 \\
\hline $\mathrm{NaF}$ & 0.58 \\
\hline $\mathrm{NaNO}_{3}$ & 13.74 \\
\hline TBP & 11.45 \\
\hline $\mathrm{Na}_{2} \mathrm{SO}_{4}$ & 1.43 \\
\hline Water & 528.0 \\
\hline
\end{tabular}


Table 36. Tank W25 grouts: comparative evolution of penetration resistance

\begin{tabular}{ccc}
\hline $\begin{array}{c}\text { Time } \\
\text { (d) }\end{array}$ & $\begin{array}{c}\text { Surrogate } \\
\text { W25 grout } \\
(\mathrm{psi})\end{array}$ & $\begin{array}{c}\text { Actual W25 } \\
\text { waste grout }\end{array}$ \\
\hline 1 & 1420 & 1400 \\
2 & 2080 & 3680 \\
3 & 3360 & 5520 \\
4 & 4880 & 6320 \\
7 & 6440 & 8400 \\
\hline
\end{tabular}

Table 37. TCLP extract concentrations for the W25 sludge sample in hot cell testing

\begin{tabular}{|c|c|c|c|c|c|c|}
\hline \multirow{2}{*}{ Analyte } & \multicolumn{3}{|c|}{ Actual W25 sludge gample } & \multirow{2}{*}{$\begin{array}{l}\text { Glass made } \\
\text { from surrogate } \\
\text { W25 sludge }\end{array}$} & \multirow{2}{*}{$\begin{array}{l}\text { Characteristic } \\
\text { limit }\end{array}$} & \multirow{2}{*}{ UTS limit } \\
\hline & $\begin{array}{l}\text { Centrifuged } \\
\text { raw sludge }\end{array}$ & Grout & Glass & & & \\
\hline \multicolumn{7}{|c|}{$\mathbf{m g} / \mathbf{L}$} \\
\hline $\mathrm{Ag}$ & 0.145 & $<0.02$ & $<0.033$ & $<0.006$ & 5 & 0.3 \\
\hline As & 0.0065 & 0.0061 & $<0.0084$ & $<0.017$ & 5 & 5 \\
\hline $\mathrm{Ba}$ & 2.34 & 0.113 & 0.33 & 1.30 & 100 & 7.6 \\
\hline $\mathrm{Cd}$ & 0.133 & $<0.02$ & $<0.03$ & $<0.002$ & 1 & 0.19 \\
\hline $\mathrm{Cr}$ & 0.93 & 0.006 & 0.037 & 0.008 & 5 & 0.86 \\
\hline $\mathrm{Hg}$ & 0.324 & 0.00363 & $<0.0033$ & & 0.2 & 0.025 \\
\hline $\mathrm{Ni}$ & 0.145 & $<0.02$ & 0.19 & 0.367 & $a$ & 5 \\
\hline $\mathrm{Pb}$ & 0.232 & 0.021 & 0.60 & 0.198 & 5 & 0.37 \\
\hline $\mathrm{Se}$ & 0.0192 & 0.0133 & $<0.0084$ & $<0.022$ & 1 & 0.16 \\
\hline $\mathrm{Tl}$ & $<0.005$ & $<0.005$ & $<0.17$ & $<0.013$ & $a$ & 0.078 \\
\hline \multicolumn{7}{|c|}{$\mathbf{B} \boldsymbol{q} / \mathbf{m L}$} \\
\hline${ }^{60} \mathrm{Co}$ & 240 & 1.7 & & & & \\
\hline${ }^{137} \mathrm{Cs}$ & 940 & 58 & & & & \\
\hline${ }^{152} \mathrm{Eu}$ & 24 & $<5.3$ & & & & \\
\hline${ }^{154} \mathrm{Eu}$ & 12 & $<3.2$ & & & & \\
\hline Gross alpha & 280 & 5 & & & & \\
\hline Gross beta & 170,000 & 5,400 & & & & \\
\hline
\end{tabular}

${ }^{a}$ No standard specified in RCRA. 
Table 38. Product consistency test leachate concentrations (mg/L)

\begin{tabular}{|c|c|c|c|c|c|c|c|c|c|}
\hline \multirow{2}{*}{ Analyte } & \multicolumn{3}{|c|}{ Borosilicate ARM glass } & \multicolumn{3}{|c|}{ Soda-lime W25 sludge glass } & \multicolumn{3}{|c|}{ Soda-lime surrogate glass } \\
\hline & ARM010 & ARM033 & ARM045 & HOT030 & HOT042 & HOT050 & SUR015 & SUR029 & SUR044 \\
\hline $\mathrm{Al}$ & 4.97 & 4.61 & 4.83 & 1.06 & 1.01 & 1.08 & 0.83 & 0.85 & 0.863 \\
\hline B & 12.62 & 13.18 & 12.65 & $<0.080$ & $<0.080$ & $<0.080$ & $<0.080$ & $<0.080$ & $<0.080$ \\
\hline $\mathrm{Ca}$ & $<2.00$ & $<2.0$ & $<2.00$ & 23.74 & 23.26 & 23.26 & 22.91 & 23.26 & 23.69 \\
\hline $\mathrm{Fe}$ & $<0.240$ & $<0.240$ & $<0.240$ & $<0.240$ & $<0.240$ & $<0.240$ & $<0.240$ & $<0.240$ & $<0.240$ \\
\hline $\mathrm{K}$ & $<0.320$ & $<0.320$ & $<0.320$ & 2.428 & 2.410 & 2.531 & 2.910 & 2.924 & 2.980 \\
\hline $\mathrm{Mg}$ & $<0.240$ & $<0.240$ & $<0.240$ & $<0.240$ & $<0.240$ & $<0.240$ & $<0.240$ & $<0.240$ & $<0.240$ \\
\hline $\mathrm{Na}$ & 31.08 & 31.98 & 31.01 & 23.56 & 23.37 & 23.71 & 36.15 & 37.04 & 37.81 \\
\hline $\mathrm{Si}$ & 52.49 & 52.62 & 51.28 & 28.52 & 28.80 & 28.45 & 33.37 & 34.16 & 34.67 \\
\hline $\mathrm{Sr}$ & 0.015 & 0.013 & 0.012 & 0.069 & 0.069 & 0.068 & 0.682 & 0.698 & 0.712 \\
\hline $\mathrm{Ti}$ & 0.009 & 0.010 & 0.009 & $<0.004$ & $<0.004$ & $<0.004$ & $<0.004$ & $<0.004$ & $<0.004$ \\
\hline $\mathrm{Zn}$ & 0.279 & 0.234 & 0.191 & 0.095 & 0.069 & 0.074 & 0.130 & 0.215 & 0.083 \\
\hline
\end{tabular}

Table 39. Concentrations of standards and blanks from PCT test

\begin{tabular}{|c|c|c|c|c|c|}
\hline \multirow[b]{2}{*}{ Analyte } & \multicolumn{3}{|c|}{ Standards $(\mathrm{mg} / \mathrm{L})$} & \multicolumn{2}{|c|}{ Blanks (mg/L) } \\
\hline & $\begin{array}{c}\text { Known } \\
\text { concentration of } \\
\text { ICP standard }\end{array}$ & $\begin{array}{c}\text { Found } \\
\text { concentration of } \\
\text { ICP standard }\end{array}$ & $\begin{array}{l}\text { Test standard } \\
\text { STD-001 }\end{array}$ & BLK-013 & BLK-026 \\
\hline $\mathrm{Al}$ & 4 & 3.99 & 4.27 & $<0.200$ & $<0.200$ \\
\hline B & 20 & 20.04 & 20.43 & $<0.080$ & $<0.080$ \\
\hline $\mathrm{Fe}$ & 4 & 4.10 & 4.35 & $<0.240$ & $<0.240$ \\
\hline $\mathrm{K}$ & 10 & 11.08 & 10.93 & $<0.320$ & $<0.320$ \\
\hline $\mathrm{Si}$ & 50 & 50.00 & 51.66 & 2.070 & 1.583 \\
\hline $\mathrm{Na}$ & 81 & 89.58 & 91.16 & $<1.400$ & $<1.400$ \\
\hline
\end{tabular}


Table 40. Radioelement content of $\mathbf{W} 25$ sludge glass product consistency test leachates

\begin{tabular}{lccc}
\hline \multicolumn{1}{c}{ Analyte } & HOT-030 & HOT-042 & HOT-050 \\
\hline${ }^{137} \mathrm{Cs}, \mathrm{Bq} / \mathrm{mL}$ & 120 & 120 & 120 \\
Gross beta, Bq/mL & 4800 & 4800 & 4700 \\
${ }^{90} \mathrm{Sr} /{ }^{89} \mathrm{Sr}, \mathrm{Bq} / \mathrm{mL}$ & 25 & 42 & 6.3 \\
Thorium, $\mathrm{mg} / \mathrm{L}$ & $<1.65$ & $<1.65$ & $<1.65$ \\
Uranium, $\mathrm{mg} / \mathrm{L}$ & $<3.30$ & $<3.30$ & $<3.30$ \\
\hline
\end{tabular}




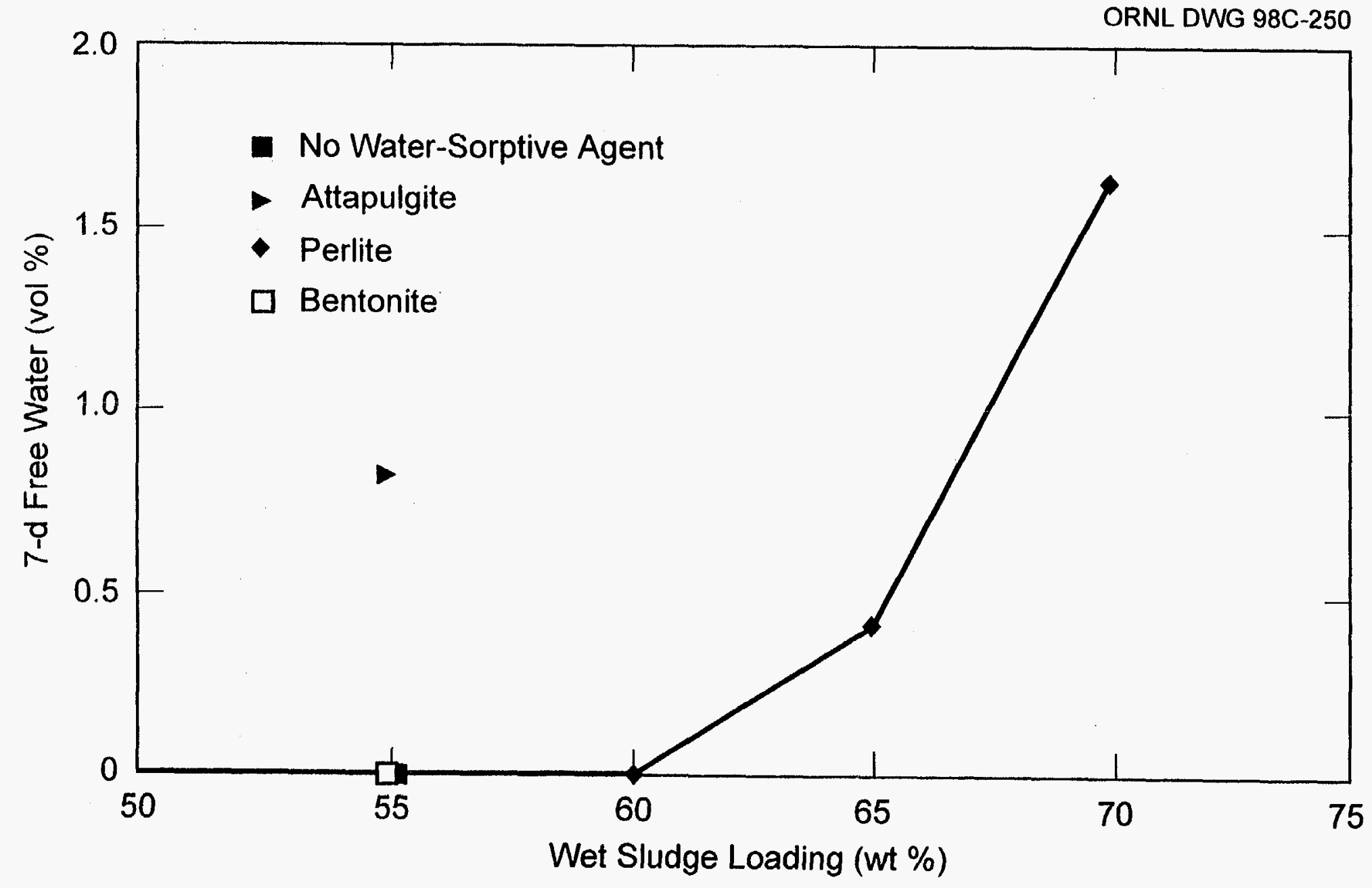
Fig. 1. Testing free water with variations on the dry blend developed for the overall weighted average surrogate sludge
(grout series 01-07). 


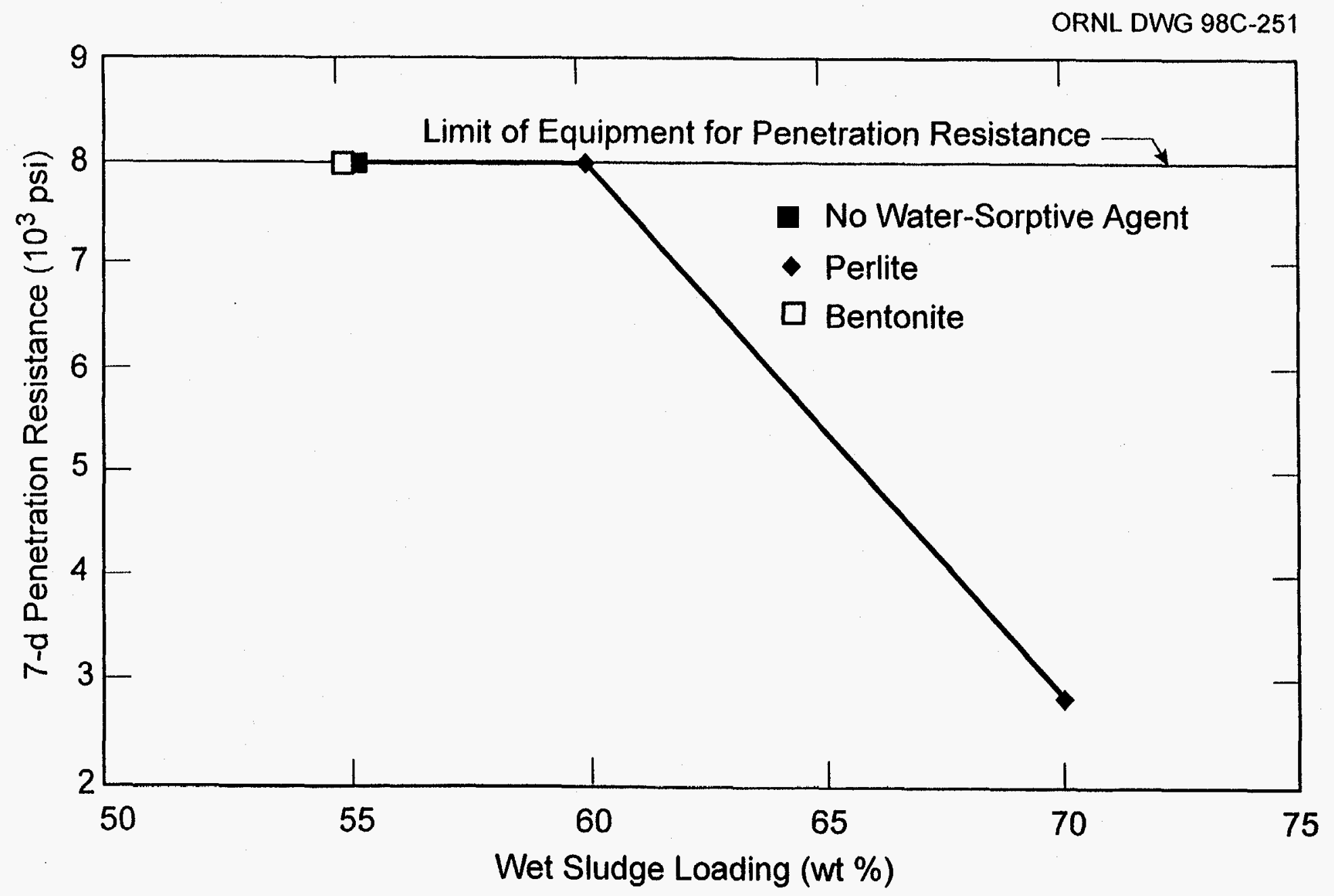

Fig. 2. Testing penetration resistance with variations on the dry blend developed for the overall weighted average surrogate sludge (grout series 01-07). 


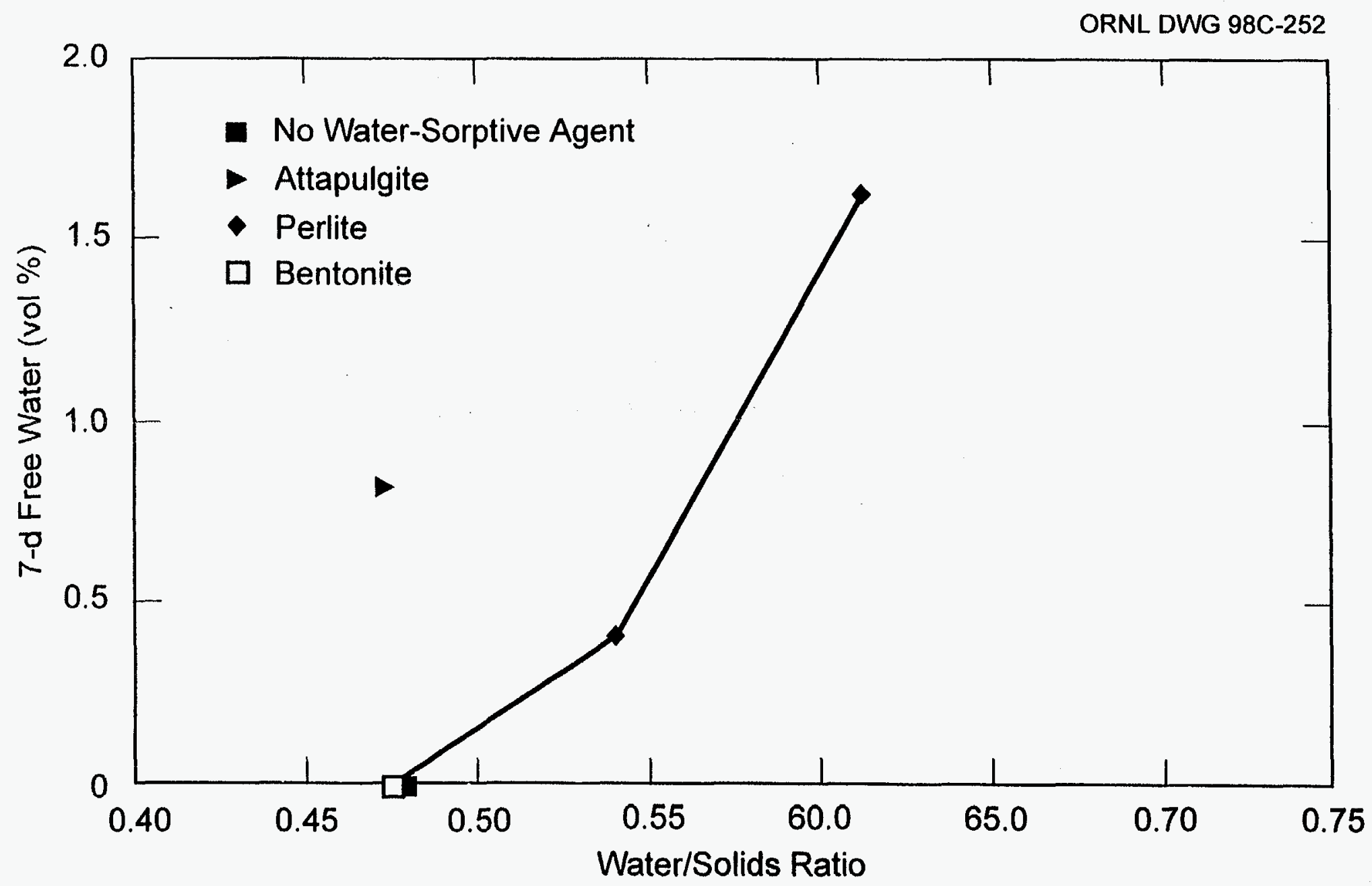

Fig. 3. Testing free water with variations on the dry blend developed for the overall weighted average surrogate sludge (grout series 01-07). 


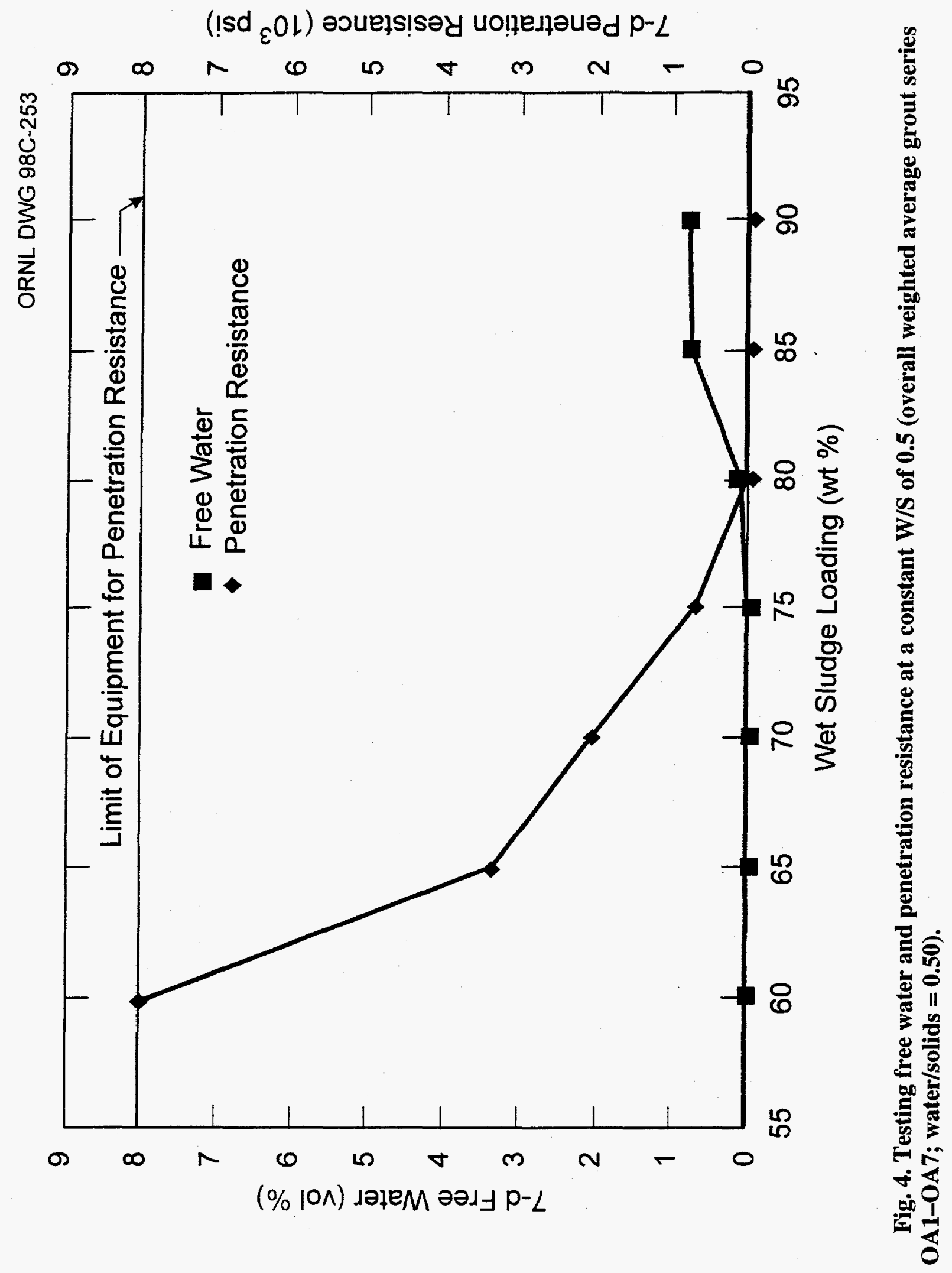




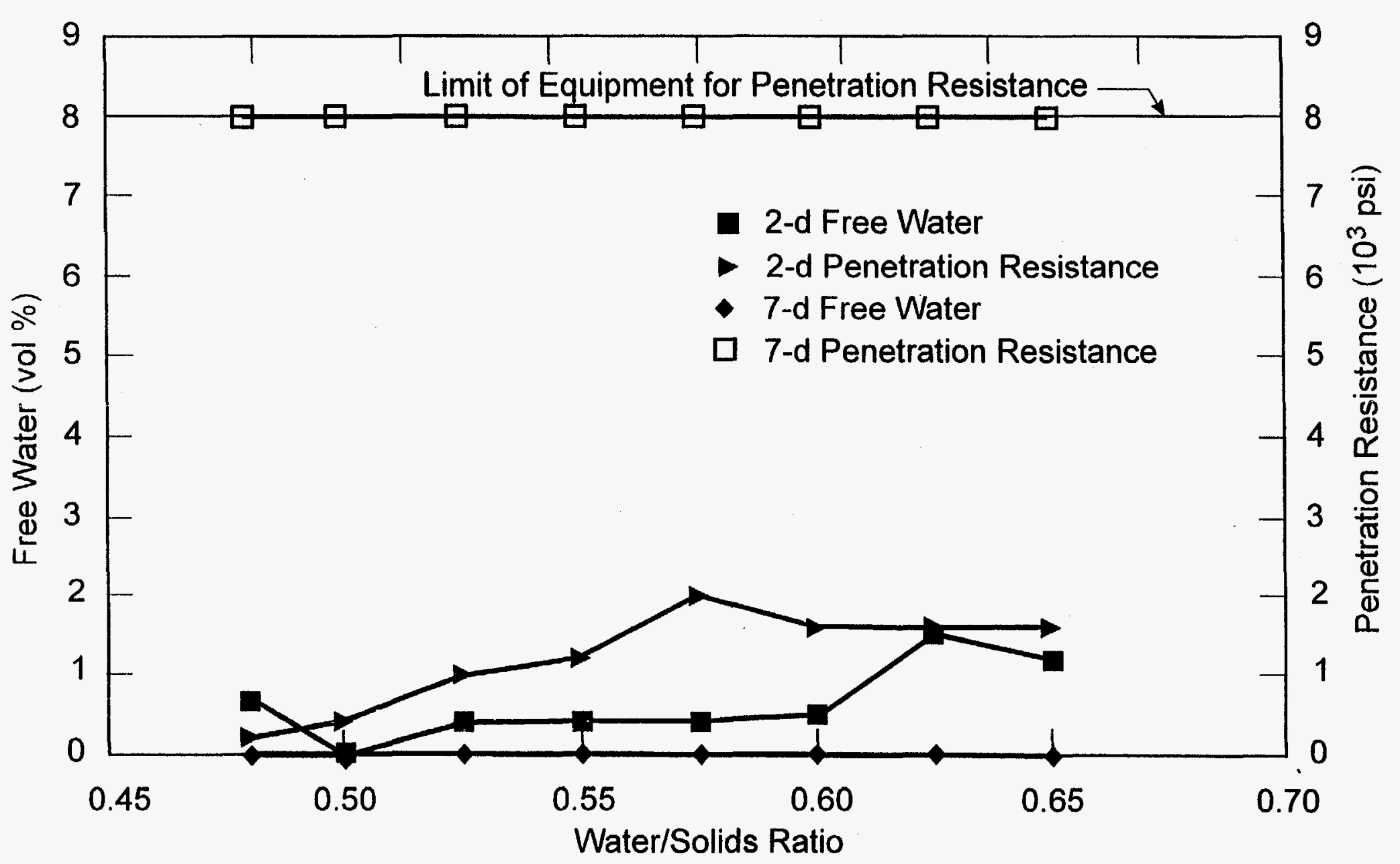

Fig. 5. Testing free water and penetration resistance at a constant loading of 60 wt $\%$ (overall weighted average grout series OB1-OB8; wet sludge loading = $60 \mathrm{wt} \%$ ). 


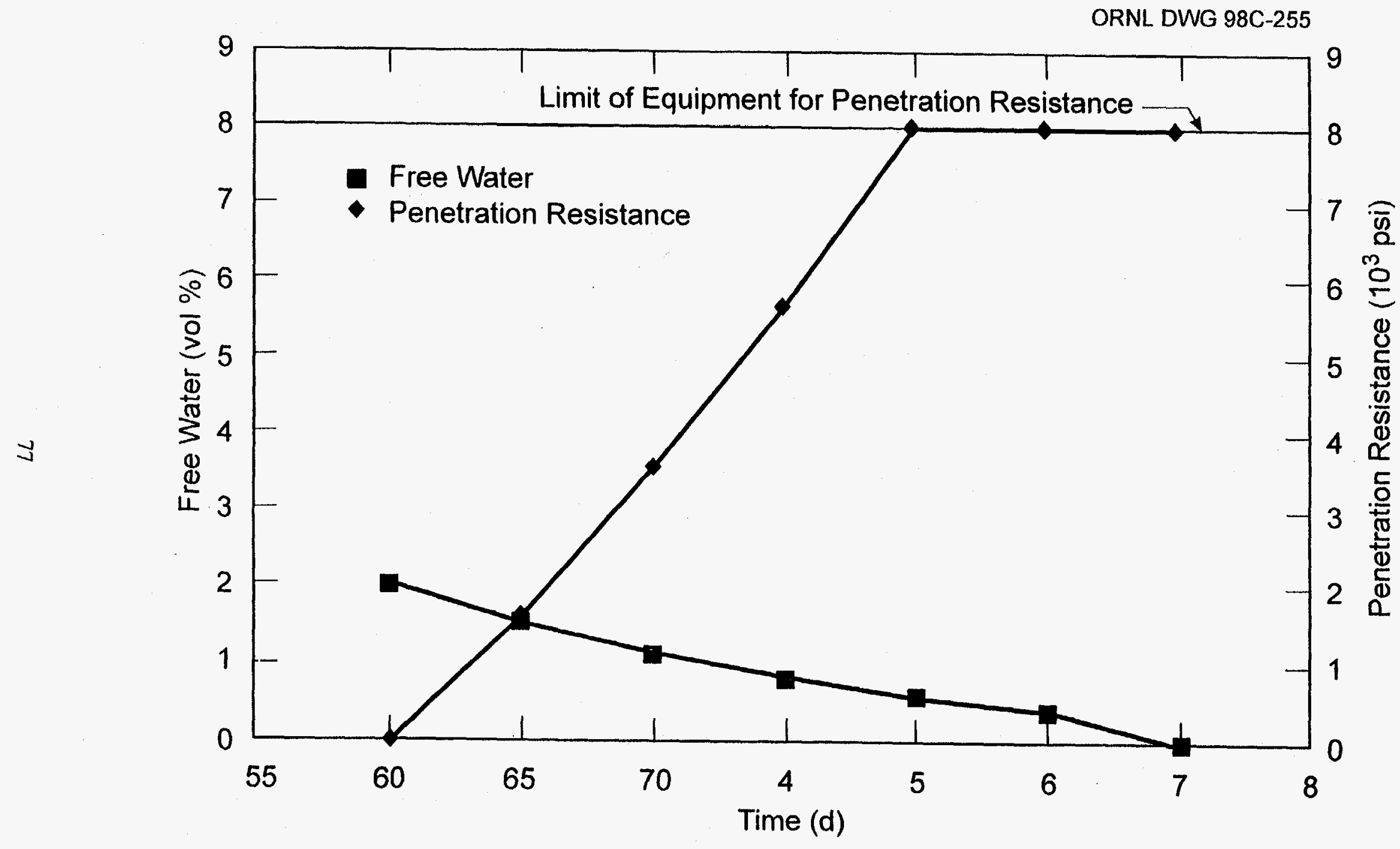

Fig. 6. Free water and penetration resistance with time for $60 \mathrm{wt} \%$ wet sludge and $\mathrm{W} / \mathrm{S}$ of 0.625 (overall weighted average grout series OB1-OB8; wet sludge loading $=60 \mathrm{wt} \%$; water/solids $=0.625$ ). 
ORNL DWG 98C-256

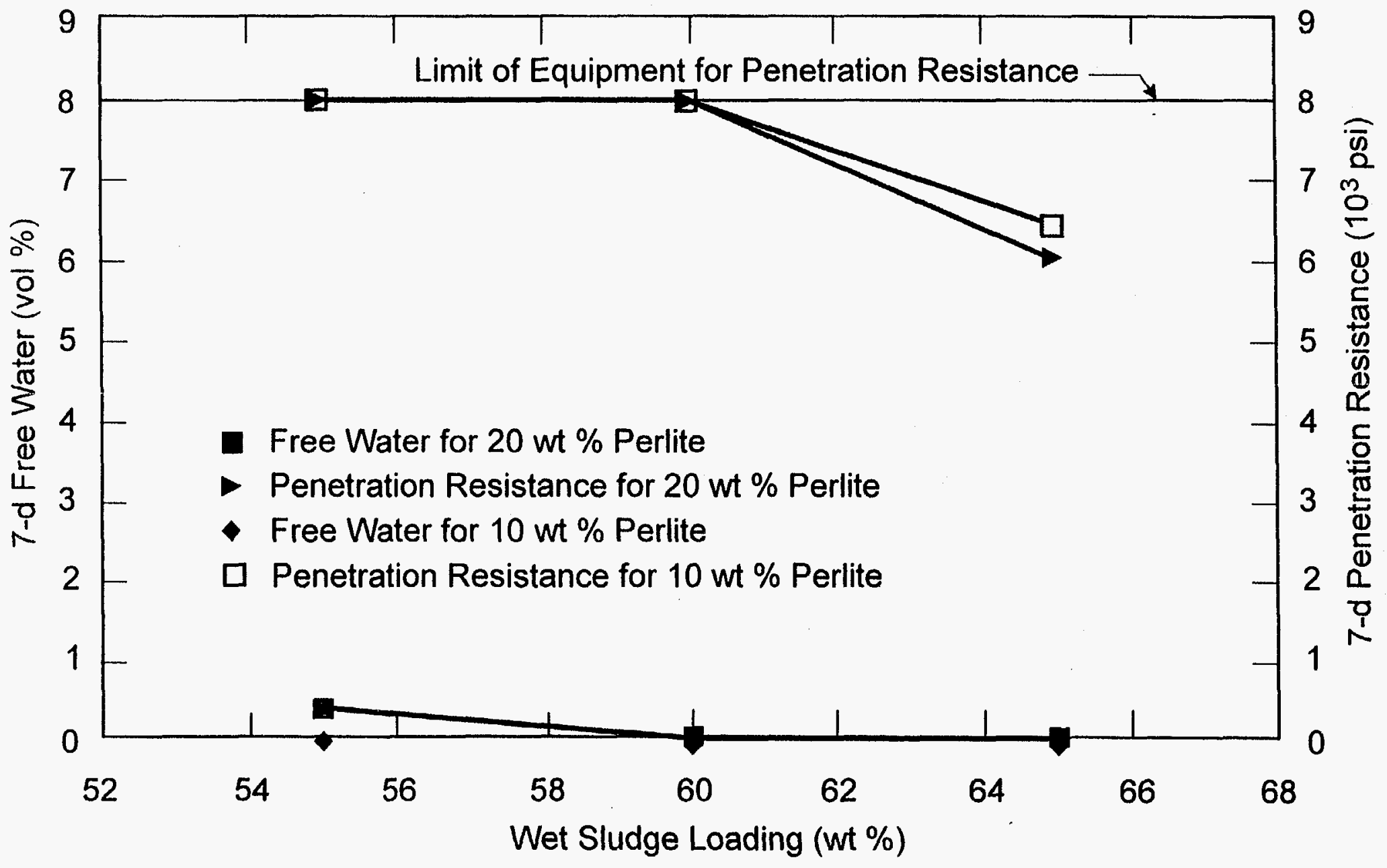

Fig. 7. Free water and penetration resistance testing lower perlite contents in the dry blend (overall weighted average grout series OC1-OC6). 


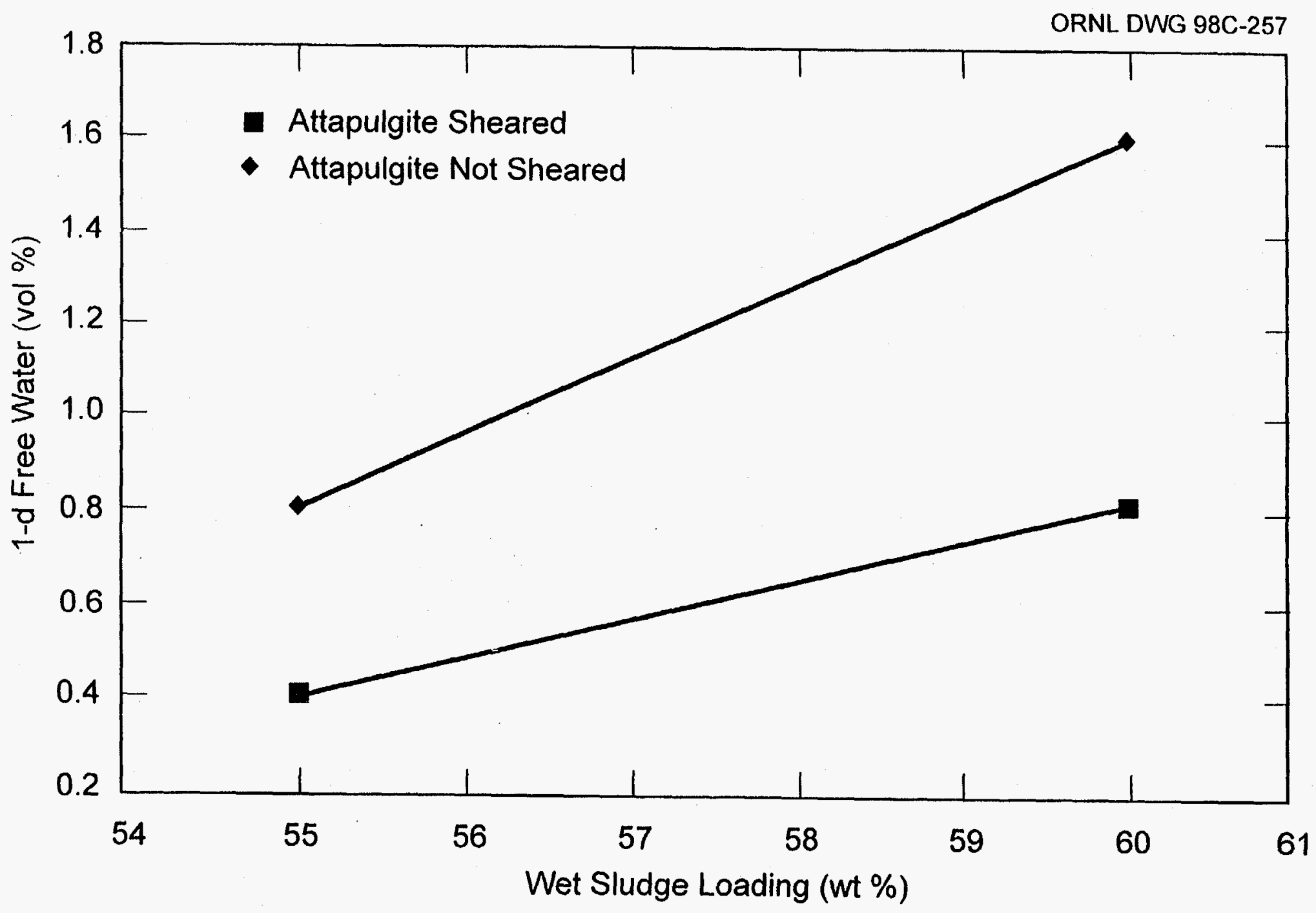

Fig. 8. Free water testing replacing perlite in the dry blend with attapulgite: sheared and nonsheared (overall weighted average grout series OD1-OD4). 


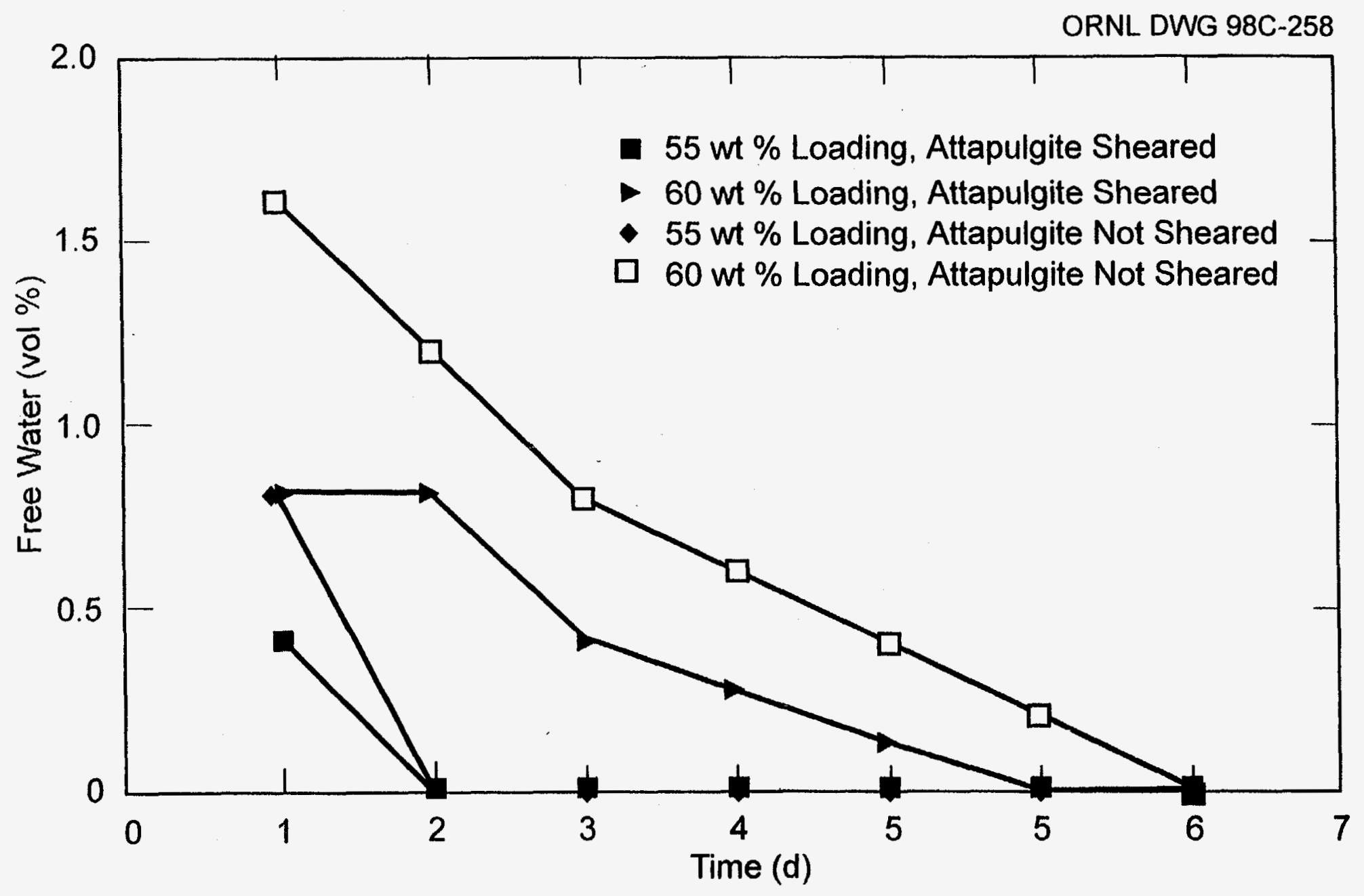

Fig. 9. Free water testing replacing perlite in the dry blend with attapulgite: sheared and nonsheared (overall weighted average grout series OD1-OD4). 


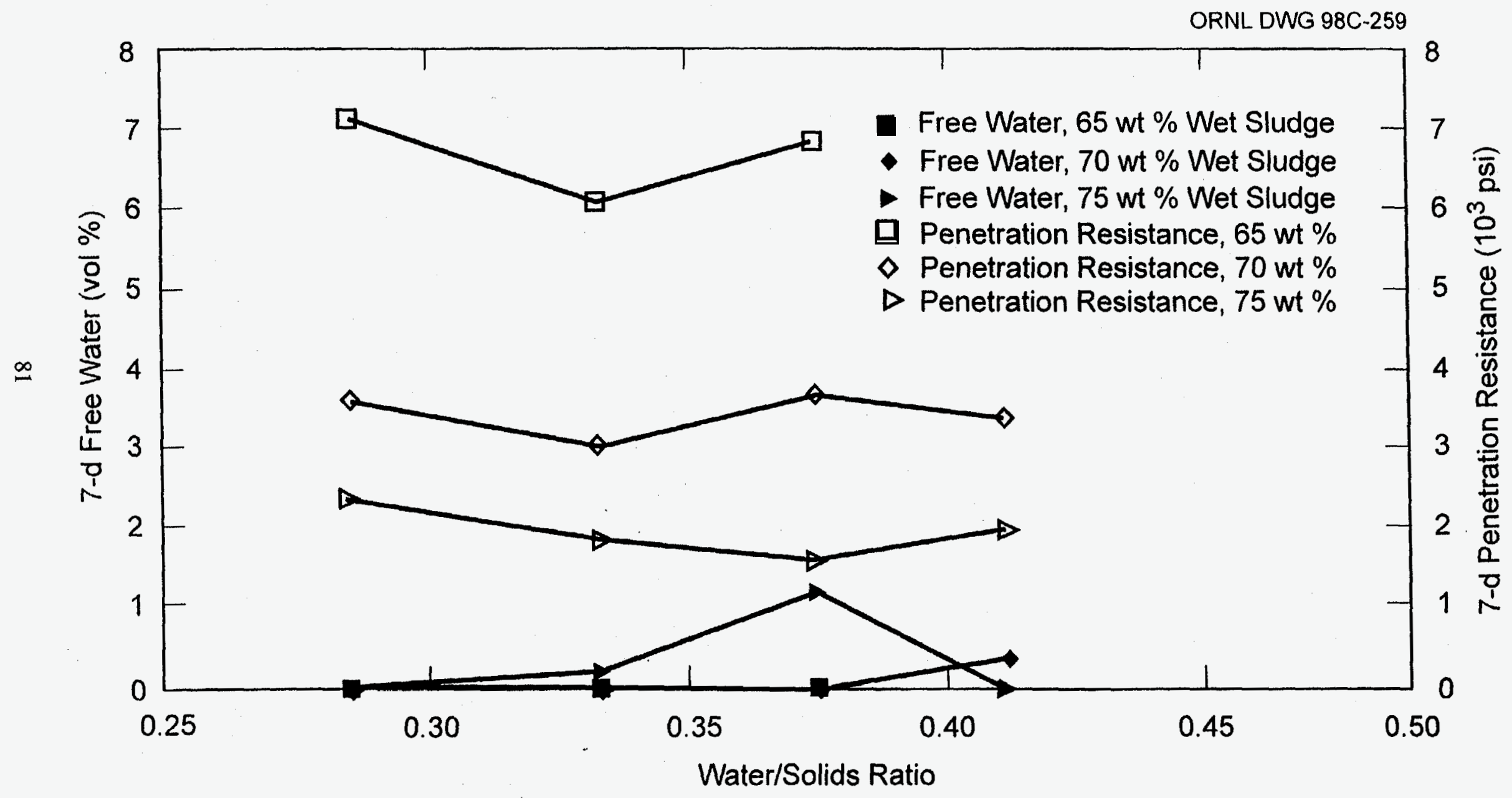

Fig. 10. Free water and penetration resistance testing varying waste loading and W/S (overall weighted average grout series OF1-OF11). 


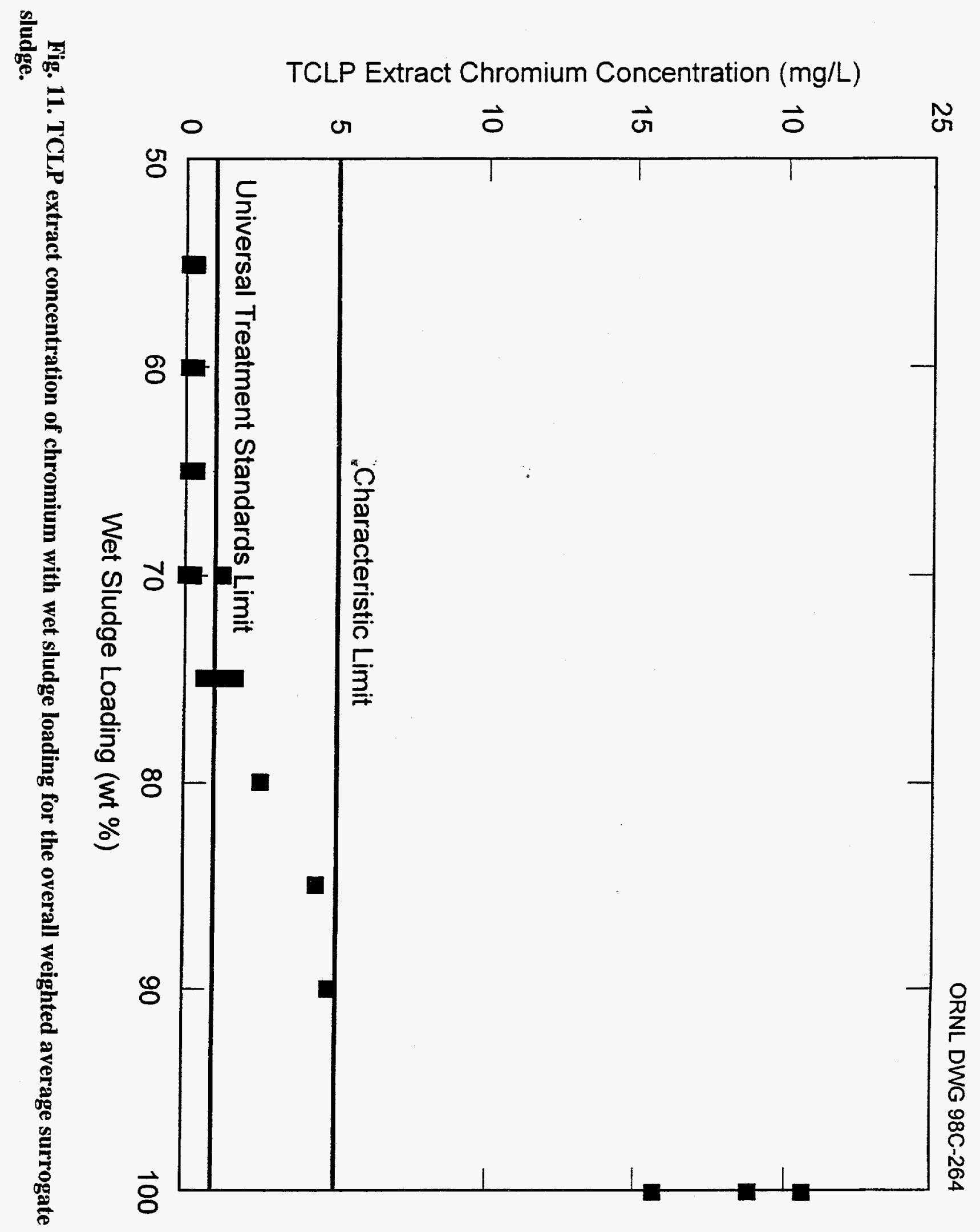




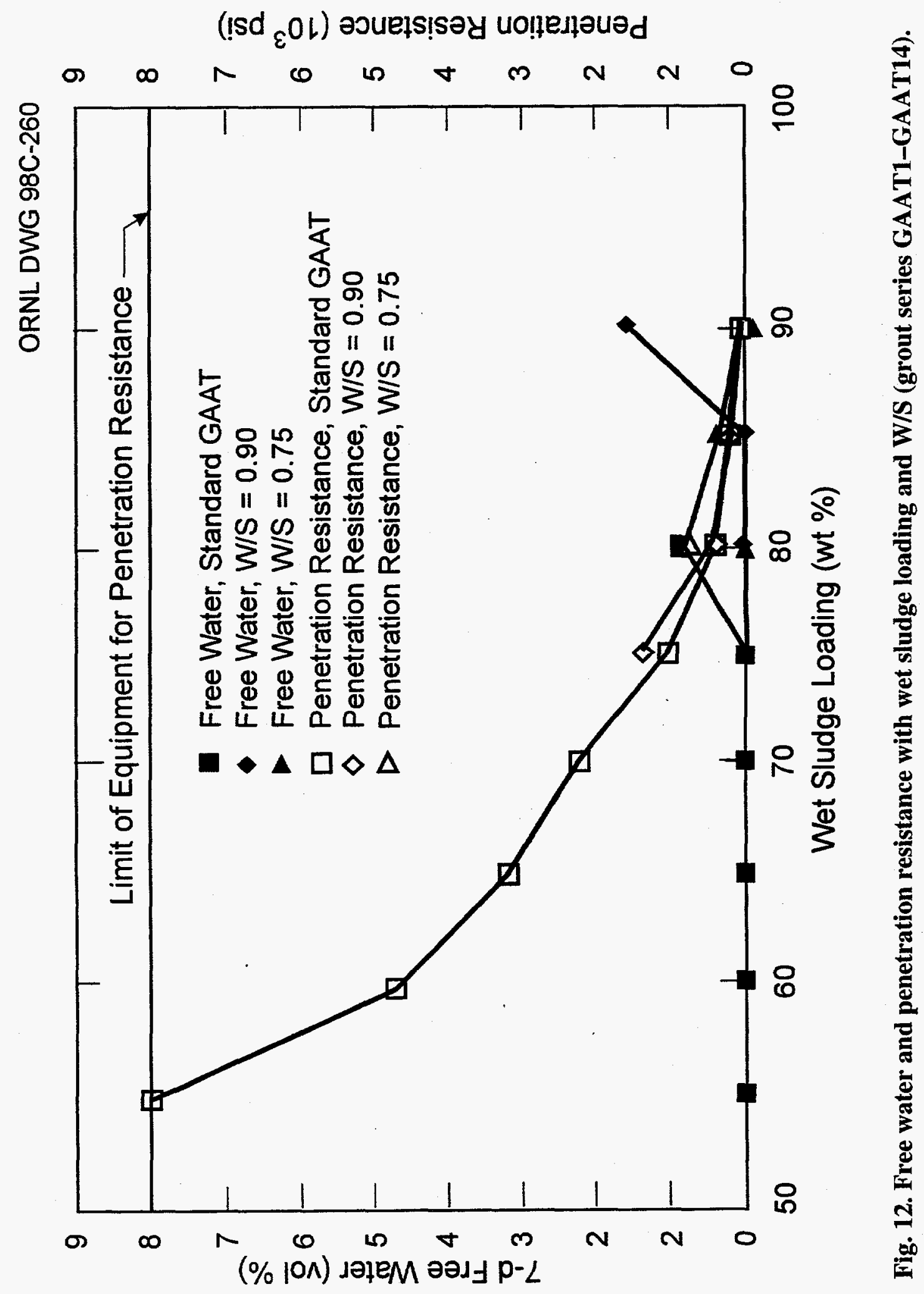


ORNL DWG 98C-261

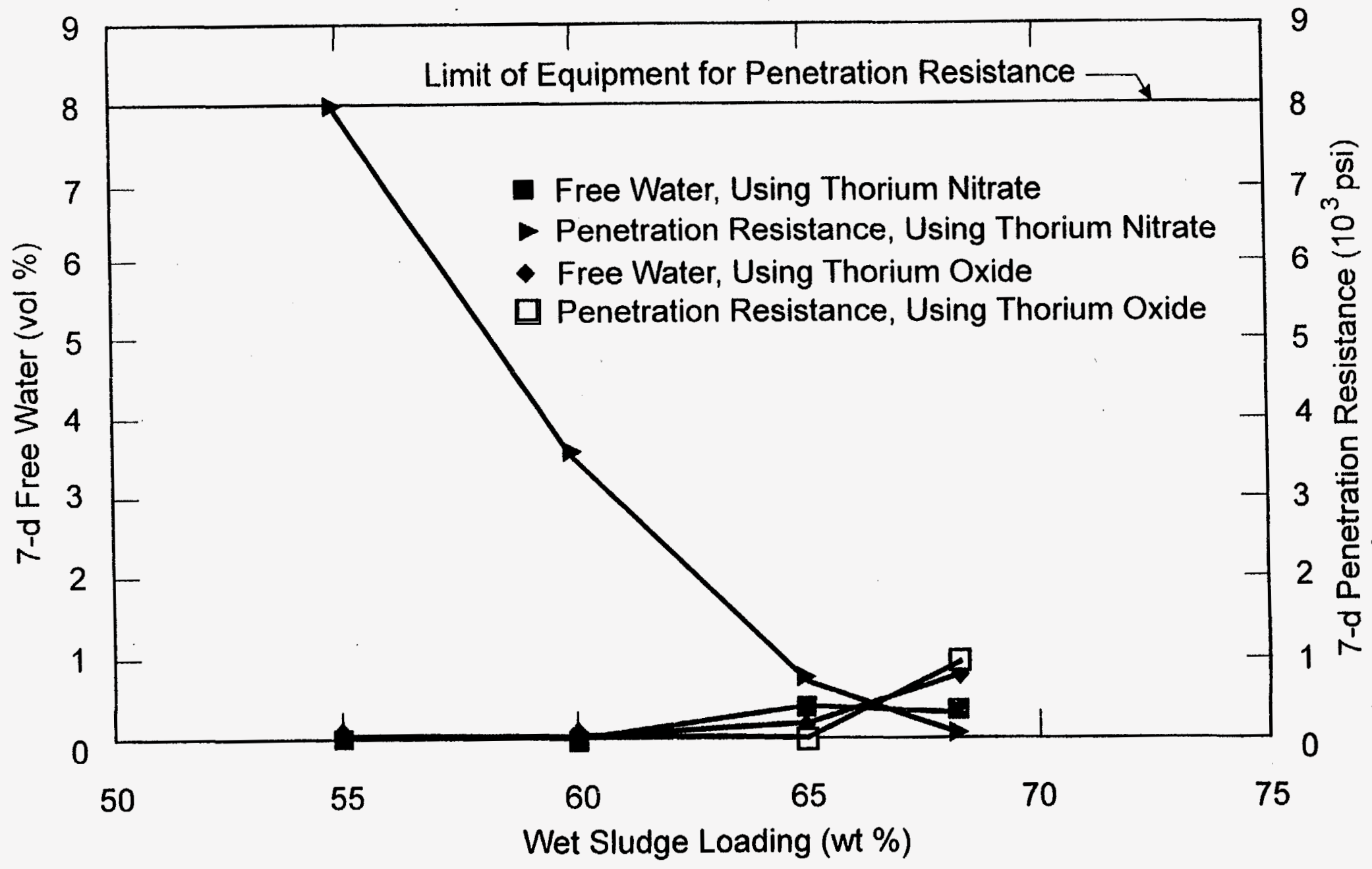

Fig. 13. Free water and penetration resistance with wet sludge loading (grout series OHF1A-OHF4). 


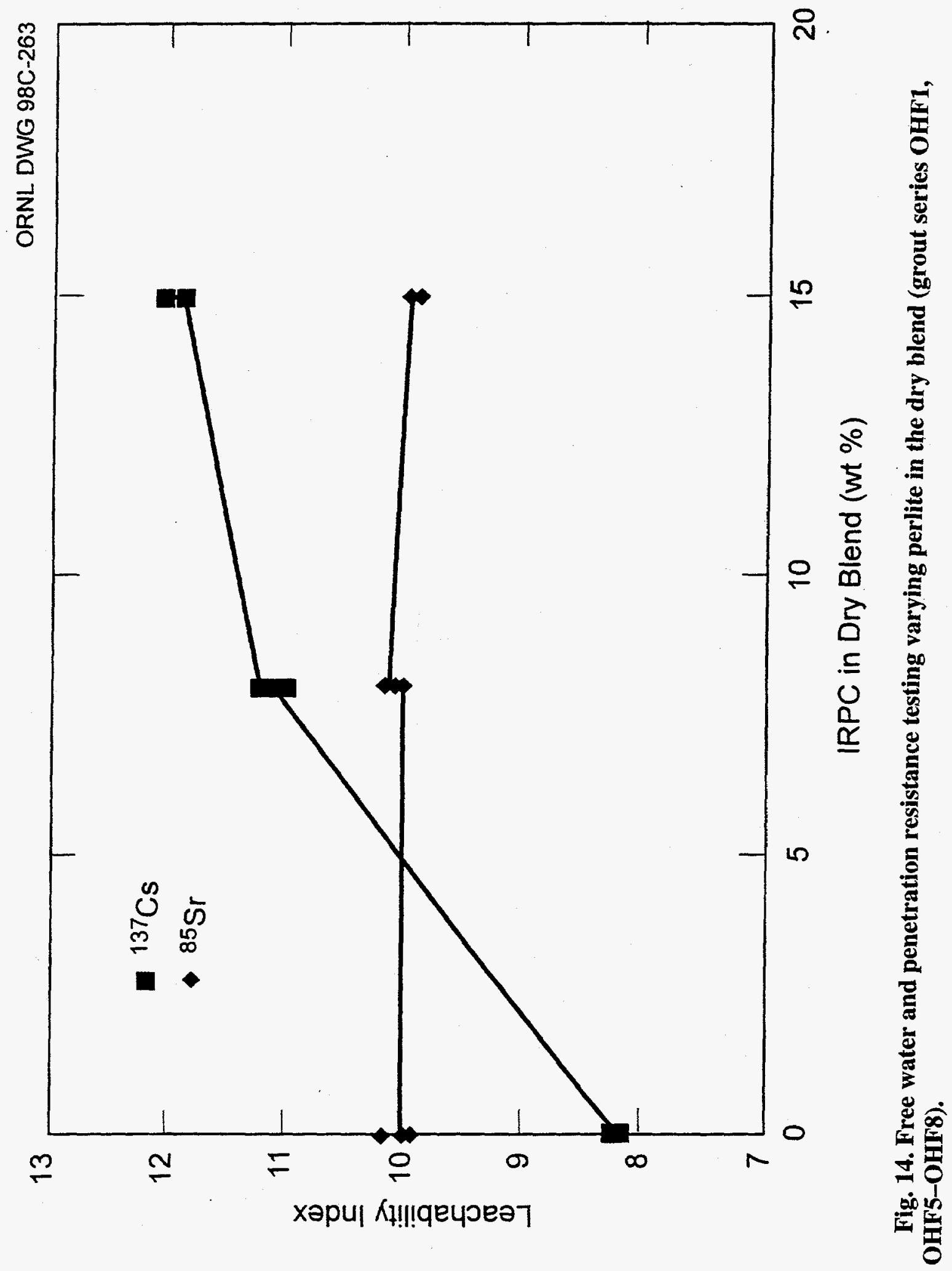




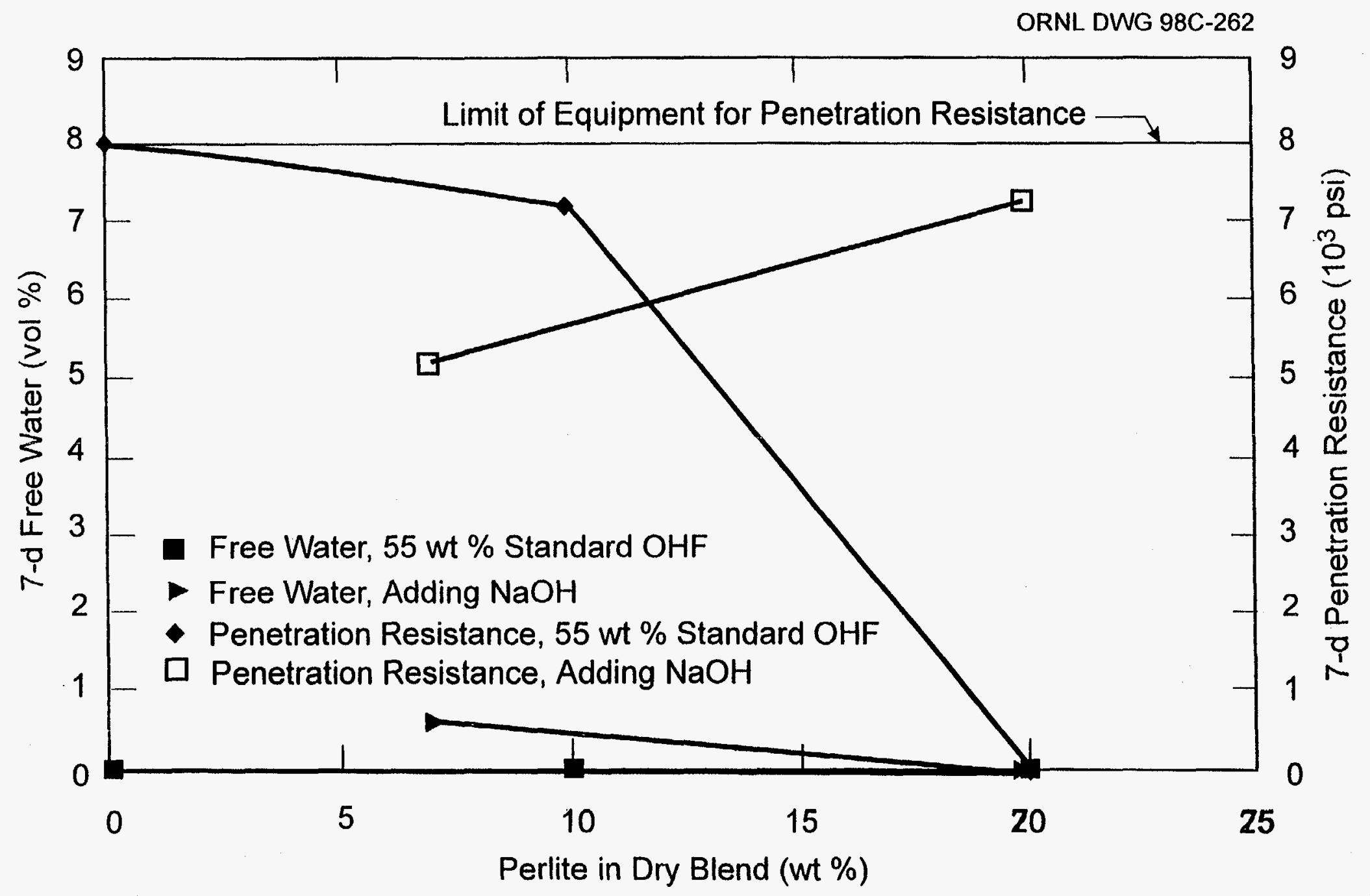

Fig. 15. Leachability index as a function of the IRPC in the dry blend varying IRPC in the overall weighted average standard sensitivity grout. 


\section{INTERNAL DISTRIBUTION}

\author{
1-3. T. B. Conley \\ 4. D. G. Cope \\ 5. A. J. Mattus \\ 6. C. H. Mattus \\ 7. G. B. Ganapathi \\ 8. R. T. Jubin \\ 9. C. M. Kendrick \\ 10-12. T. E. Kent \\ 13. P. McGinnis \\ 14. T. E. Myrick
}

\author{
15. T. H. Monk \\ 16. S. M. Robinson \\ 17. C. B. Scott \\ 18-27. R. D. Spence \\ 28. J. R. Trabalka \\ 29. T. M. Welch \\ 30. Central Research Library \\ 31. Laboratory Records - RC \\ 32-33. Laboratory Records - for \\ submission to OSTI
}

\section{EXTERNAL DISTRIBUTION}

34. Mary K. Andrews, Westinghouse Savannah River Company, P.O. Box 616, Bldg. 773-A/B-120, Aiken, South Carolina 29808

35. John Harbour, Westinghouse Savannah River Company, P.O. Box 616, Bldg. 773-A/B-120, Aiken, South Carolina 29808

36. William Holtzscheiter, Westinghouse Savannah River Company, P.O. Box 616, Bldg. 773-A-232, Aiken, South Carolina 29808

37. David A. Hutchins, U.S. Department of Energy, 55 Jefferson, MS-EW92, Oak Ridge, Tennessee 37830

38. Cavanaugh Mims, U.S. Department of Energy, 55 Jefferson, MS-EW92, Oak Ridge, Tennessee 37830

39. Johnny O. Moore, U.S. Department of Energy, 55 Jefferson, MS-EW92, Oak Ridge, Tennessee 37830

40. Jacquie Noble-Dial, U.S. Department of Energy, 55 Jefferson, MS-EW92, Oak Ridge, Tennessee 37830

41. Gary L. Riner, U.S. Department of Energy, 55 Jefferson, MS-EW92, Oak Ridge, Tennessee 37830

42-49. Terri Stewart, Pacific Northwest National Laboratory, Battelle Blvd., MS-K9-69, Richland, Washington 99352 